
Knjižnica Ludus · 21 · ISSN 2630-3809

Urednica zbirke · Silva Bratož

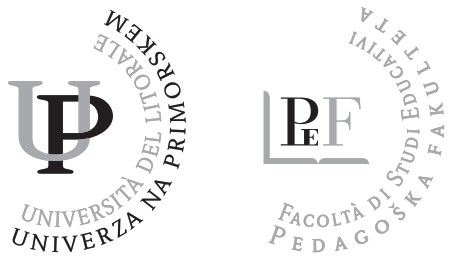




\title{
Zgodnje gibalno učenje in poučevanje
}

\author{
Iztok Retar
}

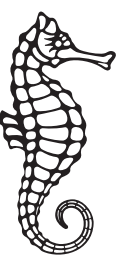




\section{Zgodnje gibalno učenje in poučevanje}

Iztok Retar

Recenzenta · Miha Marinšek in Iva Blažević

Likovna zasnova knjižnega bloka · Tilen Žbona

Oblikovanje ovitka Alen Ježovnik

Slika na naslovnici $\cdot$ Iztok Retar

Lektura in prelom · Davorin Dukić

Knjižnica Ludus $\cdot 21 \cdot$ ISSN 2630-3809

Urednica zbirke · Silva Bratož

Izdala in založila · Založba Univerze na Primorskem

Titov trg 4, 6000 Koper

www.hippocampus.si

Glavni urednik · Jonatan Vinkler

Vodja založbe · Alen Ježovnik

Koper $\cdot 2022$

(c) 2022 Iztok Retar

Brezplačna elektronska izdaja

https://www.hippocampus.si/ISBN/978-961-293-141-4.pdf

https://www.hippocampus.si/ISBN/978-961-293-142-1/index.html

https://doi.org/10.26493/978-961-293-141-4

(c) Br.SA

Kataložni zapis o publikaciji (CIP) pripravili

v Narodni in univerzitetni knjižnici v Ljubljani

COBISS.SI-ID 96252931

ISBN 978-961-293-141-4 (PDF)

ISBN 978-961-293-142-1 (HTML) 


\section{VSEBINA}

I. UVOD V GIBALNO POUČEVANJE

\section{GIBALNO POUČEVANJE: TEMELJNI RAZMISLEKI}

Opuščanje gibanja je, žal, že pogosta negativna praksa

Kakovostni gibalni razvoj otrok kot gradnik zdravega življenjskega sloga

Kaj je učenje?

Moški nasproti ženskim športom?

Opredelitev pojmov delovne kompetence, gibalne sposobnosti

in gibalne kompetence

Gibalne sposobnosti kot predmet zgodnjega gibalnega poučevanja

Gibalne kompetence

Nevrološke osnove delovanja gibalnega sistema kot podlaga

za gibalno učenje in poučevanje

Kako delujejo možgani v povezavi z gibanjem?

Nadzor gibanja

II. GIBALNI RAZVOJ OTROKA 
Spoznavni razvoj $\quad 35$

Čustveno-socialni razvoj 36

Razvoj gibalnih sposobnosti kot gradnik gibalnega razvoja 37

Značilnosti gibalnega razvoja v zgodnjem otroštvu 39

Opredelitev gibalnega razvoja $\quad 42$

Pisanje z roko kot kazalnik razvoja gibalnih sposobnosti 45

Pomen in vloga elementarnih gibalnih vzorcev $v$ gibalnem razvoju otroka

GIBALNE SPOSOBNOSTI

Delitev gibalnih sposobnosti 50

RAVNOTEŽJE

Dejavniki, ki pogojujejo ravnotežje $\quad 52$

Merski postopki za ugotavljanje ravnotežja 53

Metode razvoja ravnotežja $\quad 54$

KOORDINACIJA

Osnovne značilnosti koordiniranega gibanja 56

Dejavniki, od katerih je odvisna koordinacija 57

Merski postopki za ugotavljanje razvitosti koordinacije 58

Sredstva in metode za razvoj koordinacije $\quad 58$

$\begin{array}{ll}\text { Pomen koordinacije } & 59\end{array}$

$\begin{array}{ll}\text { GIBLJIVOST } & 61\end{array}$

$\begin{array}{ll}\text { Prirojenost gibljivosti } & 62\end{array}$

Dejavniki gibljivosti $\quad 62$

Notranji dejavniki $\quad 62$

Zunanji dejavniki $\quad 64$

$\begin{array}{ll}\text { Struktura gibljivosti } & 65\end{array}$

Merski postopki za ugotavljanje gibljivosti $\quad 65$

$\begin{array}{ll}\text { Metode razvoja gibljivosti } & 66\end{array}$

Dinamična metoda razvoja gibljivosti 66

Statična metoda razvoja gibljivosti $\quad 66$

$\begin{array}{ll}\text { Pomen dobre gibljivosti } & 67\end{array}$

MOČ $\quad 69$

$\begin{array}{ll}\text { Morfološki dejavniki moči } & 70\end{array}$

Funkcionalni dejavniki moči 70

$\begin{array}{ll}\text { Psihološki dejavniki moči } & 71\end{array}$

Biološki dejavniki moči $\quad 72$

$\begin{array}{ll}\text { Metode razvoja moči } & 73\end{array}$

$\begin{array}{ll}\text { Merski postopki za ugotavljanje moči } & 73\end{array}$ 
$\begin{array}{ll}\text { HITROST } & 75\end{array}$

Dejavniki, ki vplivajo na razvoj hitrosti $\quad 75$

$\begin{array}{ll}\text { Fiziološki dejavniki } & 76\end{array}$

$\begin{array}{ll}\text { Biološka dejavnika } & 76\end{array}$

$\begin{array}{ll}\text { Psihološka dejavnika } & 77\end{array}$

$\begin{array}{ll}\text { Morfološki dejavniki } & 77\end{array}$

$\begin{array}{ll}\text { Merski postopki za ugotavljanje hitrosti } & 78\end{array}$

$\begin{array}{ll}\text { Sredstva za razvoj hitrosti } & 78\end{array}$

$\begin{array}{ll}\text { NATANČNOST } & 79\end{array}$

Sposobnosti zadevanja z vodenim projektilom 80

$\begin{array}{ll}\text { Sposobnosti zadevanja z vrženim projektilom } & 80\end{array}$

Merski postopki za ugotavljanje natančnosti 80

$\begin{array}{ll}\text { Metode razvoja natančnosti } & 81\end{array}$

VZDRŽLJIVOST

Dejavniki, ki pogojujejo vzdržljivost $\quad 84$

Metode razvoja vzdržljivosti $\quad 84$

III. GIBALNO UČENJE IN POUČEVANJE

SPLOŠNO O GIBALNEM UČENJU IN POUČEVANJU

PROCEDURALNI SPOMIN

RELATIVNE PRIMERJAVE MOŽGANOV ALI ZAKAJ GIBALNIH PROBLEMOV

NIKOLI NE ZMANJKA

FAZE POUČEVANJA IN UTRJEVANJE ZNANJA O GIBANJU 99

1. faza: površna in groba izvedba gibanja ter razpršenost informacij 99

2. faza: usmerjeno razlikovanje, osredotočanje vzburjenosti

$\begin{array}{ll}\text { in koncentracija } & 100\end{array}$

3. faza: avtomatizacija (samodejno delovanje procesov) in stabilizacija $\begin{array}{ll}\text { (ustalitev, utrditev gibalnih programov) } & 101\end{array}$

4. faza: modifikacija (prilagajanje, dopolnjevanje gibanja) in asociacija (združevanje spominskih informacij) ter usklajevalni proces 102

$\begin{array}{ll}\text { NAPAKE PRI POPRAVLJANJU NAPAK } & 105\end{array}$

IZHODIŠČA ZA UČINKOVITO GIBALNO POUČEVANJE 107

KRATEK PREGLED GIBALNEGA POUČEVANJA V ZGODNJEM OTROŠTVU V SLOVENIJI 109 
MOTIVACIJSKI DEJAVNIKI GIBALNEGA/ŠPORTNEGA UDEJSTVOVANJA

Preseganje otrokove cone udobja kot motivacijski pristop vzgojitelja

Notranja in zunanja motivacija pri gibalnem poučevanju

Tekmovanje in izločanje kot motivacija?

KOMUNICIRANJE KOT PODPORA GIBALNEMU UČENJU

Vrste komuniciranja

Značilnosti učinkovite komunikacije

Smernice za kakovostno komuniciranje pri gibalnem poučevanju

POMEN KAKOVOSTNE IN PREGLEDNE DEMONSTRACIJE/PRIKAZA

GIBANJA

VREDNOTENJE KOT PODLAGA ZA ZAGOTAVLJANJE KAKOVOSTI

$\checkmark$ GIBALNEM POUČEVANJU

OPREDELITEV POJMOV POUK IN POUČEVANJE

DIDAKTIKA KOT MOST MED TEORIJO IN PRAKSO

UČNE OBLIKE

UČNE METODE

KRITERIJI ETIČNEGA ZGODNJEGA GIBALNEGA POUČEVANJA

STRUKTURA UČNE ENOTE GIBALNEGA POUČEVANJA

Smernice za oblikovanje strukture učne enote

SNOVNA IN ORGANIZACIJSKA PRIPRAVA

IGRA KOT SREDSTVO ZGODNJEGA GIBALNEGA POUČEVANJA

Nestrukturirana gibalna igra

Didaktična gibalna igra

Elementarne igre

Cilji elementarnih iger

Delitev elementarnih iger

Načela postopne obremenitve pri igrah 
UČINKOVITO UPRAVLJANJE ŠPORTNE INFRASTRUKTURE

VSEŽIVLJENJSKO (GIBALNO) UČENJE

IZHODIŠČNE USMERITVE KAKOVOSTNE IN UČINKOVITE GIBALNE OBRAVNAVE OTROK

NAČINI RAZVIJANJA GIBALNE KOMPETENTNOSTI OTROK S POMOČJO

SPODBUJANJE VSEŽIVLJENJSKEGA POUČEVANJA ZA ZDRAV ŽIVLJENJSKI SLOG

OBRAZLOŽITEV IZBRANIH NAJPOGOSTEJŠIH POJMOV V GIBALNEM POUČEVANJU

POVZETEK

SUMMARY

LITERATURA

RECENZIJI 



\section{SLIKE IN PREGLEDNICE}

139 Slika 1: Struktura učne enote gibalnega poučevanja

151 Slika 2: Značilnosti elementarne gibalne igre

172 Slika 3: Ocena področij delovanja vzgojiteljev, ki prispevajo k inovativnosti na področju zgodnjega gibalnega poučevanja v praksi

176 Slika 4: Mrežna matrika inovativnega zgodnjega gibalnega poučevanja

21 Preglednica 1: Teoretični model strukture delovnih kompetenc inovativnega gibalnega poučevanja

22 Preglednica 2: Kje in kako uspešno so vzgojitelji razvijali svoje delovne kompetence za naloge na področju gibanja

40 Preglednica 3: Faze in stopnje gibalnega razvoja

56 Preglednica 4: Osnovne značilnosti koordiniranega gibanja

99 Preglednica 5: Faze poučevanja in utrjevanje znanja o gibanju

107 Preglednica 6: Izhodišča učinkovitega poučevanja

158 Preglednica 7: Primer zapisnika o nezgodi oz. poškodbi

173 Preglednica 8: Model inovativnega gibalnega poučevanja

175 Preglednica 9: Struktura modela faktorjev delovanja in nalog, ki jih vzgojiteljice izvajajo v praksi in lahko prispevajo k inovativnosti na področju zgodnjega gibalnega poučevanja 



\section{PREDGOVOR}

Vloga in pomen vzgojitelja na področju zgodnjega gibalnega poučevanja sta neprecenljiva za učinkovito razvijanje gibalne kompetentnosti $v$ zgodnjem otroštvu v vrtcih, v katerih je v Sloveniji že več kot 76,8 \% celotne populacije otrok in 10.782 strokovnih delavcev - vzgojiteljev in pomočnikov (Statistični urad Republike Slovenije, 2016).

Ker je tako v Sloveniji kot drugod vse več gibalno neaktivnih otrok (Završnik in Pišot, 2005; Gabrijelčič Blenkuš, 2013; Grey-Thompson, Huppert, Keeley in Leslie, 2014), smo vzgojitelji družbeno in poklicno odgovorni za ohranjanje in povečanje kakovostnega telesnega gibanja otrok - še posebej v zgodnjem otroštvu, ko se gibalne sposobnosti še razvijajo in se začne oblikovati otrokov življenjski slog.

Otroci namreč prihajajo iz različnih družinskih okolij in imajo različne dedne zasnove, kar odločilno vpliva na njihov gibalni razvoj. Prav zato je gibalno poučevanje izredno občutljiv in zapleten proces, $v$ katerem ima ključno vlogo vzgojitelj. Prepoznati mora potenciale posameznika in ugotoviti, kako doseči, da jih bo kar najbolj razvil, pri čemer mora upoštevati profesionalna načela poučevanja. Vzgojitelj sledi učnemu načrtu - kurikulu (Bahovec, 2001), vendar glede na okolje tudi kompetentno presoja, katero pedagoško tehnologijo, metodologijo in strategijo bo izbral ter jo prilagodil v korist učenca. Zato mora vzgojitelj (p)ostati radoveden in vedoželjen kot otroci ter se ves čas učiti in raziskovati lastno prakso ter ugotovitve vnašati v poučevanje. Pri vzgojnem delu vzgojitelja usmerjajo številni cilji. Med pomembne uvrščamo predvsem razvoj ustrezne gibalne učinkovitost otroka, ki temelji na skladnem telesnem 
razvoju, razvoju gibalnih in funkcionalnih sposobnosti. Pomembno je tudi prispevanje k kakovostnemu usvajanju različnih naravnih oblik gibanja - gibalnih vzorcev, gibalnih iger in osnovnih športnih znanj, kot so npr. vožnja s kolesom, plavanje, rolanje, drsanje ... Pri tem pa ne smemo pozabiti na zagotavljanje učnega okolja, v katerem bo otrok gibanje ter šport doživljal kot prijetna in se razvijal $z$ igro.

Upoštevajoč navedena dejstva je ključni cilj znanstvene monografije predstaviti izbrana poglavja s področja gibalnega razvoja otrok in sodobnega gibalnega poučevanja $v$ zgodnjem otroštvu ter tako prispevati k osebnostni in strokovni rasti vzgojiteljev. 


\section{I. \\ UVOD V GIBALNO POUČEVANJE}





\section{GIBALNO POUČEVANJE: TEMELJNI RAZMISLEKI}

\section{OPUŠČANJE GIBANJA JE, ŽAL, ŽE POGOSTA NEGATIVNA PRAKSA}

Aktualni model gibanja, ki se je razširil v razvitih državah sveta, temelji na minimalni rabi gibanja in premikanja telesa v vsakdanjem življenju - tako pri delu kot $v$ prostočasnih dejavnostih. Zgodovinski pogled na človekov gibalni razvoj in gibalno učenje $v$ procesu evolucije kaže, da je bilo gibanje ključnega pomena za prehod iz primitivnega $v$ civilizirano obliko življenja. Poleg nedvomnih prednosti ima sodobni življenjski slog tudi slabosti, ki jih stroka (Završnik in Pišot, 2005; Gabrijelčič Blenkuš, 2013; Grey-Thompson idr., 2014) prepoznava kot sindrom primanjkljaja gibanja. Lahko bi že govorili o epidemiji gibalne nedejavnosti, ki je opredeljena kot četrti dejavnik globalne umrljivosti (WHO, 2011). Številne raziskave povzemajo, da v zgodovini človeštva še nismo bili tako malo gibalno in/ali športno aktivni. Še posebej to velja za otroke, ki so gibanje nadomestili s prezgodnjim sedenjem in ležanjem pri skoraj vseh vsakodnevnih opravilih in dejavnostih. Dandanašnje minimaliziranje gibanja, tako razvijanja prirojenih gibalnih sposobnosti otrok kot naravnih in sestavljenih oblik gibanja mladostnikov ter vzdrževanja in rehabilitacije gibalne zmogljivosti odraslih, nakazuje uvajanje trenda življenjskega sloga z minimalno rabo ali brez gibanja. Človeško telo, v dolgi evoluciji razvito za gibanje, opušča svojo ključno funkcijo in jo prepušča nadomestnim, vse pametnejšim strojem in napravam. Pri ozaveščenih posameznikih se sicer gibanje vključuje $v$ življenjski slog, vendar bolj kot kompenzacija pomanjkanja gibanja in ne kot dosedanji, za človeštvo značilni način življenja. 
Odgovor na predstavljeni problem je lahko trajnostni model gibanja, ki stremi k umeščanju gibanja v vsakodnevna opravila in k njegovemu čim daljšemu zadrževanju v dnevnem ciklu. Razumevanje in uveljavljanje tovrstnega življenjskega sloga je v domeni vsakega vzgojitelja, učitelja, drugih s poučevanjem povezanih poklicev ter učenca. Razumevanje pomena in pozitivne vloge gibanja je zato za vzgojitelje izjemnega antropološkega in aplikativnega pomena. Posledica številnih strukturnih sprememb sodobne družbe je tudi ta, da se dosedanja paradigma gibalnega poučevanja, ki je temeljila na uresničevanju želja in utemeljenih pričakovanj učencev v zvezi z učenjem številnih gibalnih dejavnosti in športov, zlagoma izteka. Nova pa šele nastaja in bo najbrž zaznamovana s spopadanjem s sedentarizmom, konkurenčnostjo informacijske in zabavne industrije ter cenovno nedostopnostjo. $V$ današnji postpermisivni dobi lahko otroka učinkovito poučujemo tudi tako, da sam in na svoj način izvaja zanj primerne gibalne dejavnosti v zanj ustreznem in varnem učnem okolju. Če smo prej - tudi zaradi koncepta permisivne vzgoje - želeli skoraj vse za otroka opraviti vzgojitelji sami, mu moramo zdaj omogočati sprejemanje odgovornosti.

\section{KAKOVOSTNI GIBALNI RAZVOJ OTROK KOT GRADNIK ZDRAVEGA ŽIVLJENJSKEGA SLOGA}

Otrokov razvoj je celosten in poteka hkrati na telesnem, gibalnem, čustvenem, socialnem in spoznavnem področju. Gallahue, Ozmun in Goodway (2011) ugotavljajo, da spremembe na enem področju vplivajo na spremembe na vseh ostalih področjih, zato je lahko model poučevanja gibalnega poučevanja, ki upošteva medsebojni vpliv, učinkovitejši od modela, ki se osredotoča izključno na gibalne vsebine. Tako tuji (Walkley, Armstrong in Clohesy, 1998; Malina, Bouchard in Bar, 2004; Gallahue idr., 2011; Harrington, 2005; Stodden idr., 2008) kot slovenski raziskovalci področja gibalnega razvoja otroka (Strel in Šturm, 1981; Rajtmajer, 1991; Pišot in Planinšec, 2010; Videmšek in Pišot, 2007; Škof, 2017; Plevnik, 2014; Retar, 2014) poudarjajo pomen kakovostnega gibalnega poučevanja v zgodnjem otroštvu, ki lahko z razvojem gibalnih sposobnosti in kompetenc pospešuje gibalni razvoj ter omogoča optimalno gibalno kompetentnost otroka. Tovrstno gibalno dejavnost avtorji razumejo tudi kot 
naložbo, ki ne prinaša neposredne koristi samo v otroštvu, temveč tudi v zreli dobi in starosti, ter ima lahko multiplikativne učinke na družbo.

\section{KAJ JE UČENJE?}

Uradna in strokovna definicija (UNESCO/ISCED) učenja iz leta 1993 (povzeto po Marentič Požarnik, 2019) je vsaka sprememba v vedenju, informiranosti, znanju, razumevanju, stališčih, spretnostih ali zmožnostih, ki je trajna in je ne moremo pripisati telesni rasti ali razvoju podedovanih vedenjskih vzorcev. Kljub preučevanju poučevanja kot celovitega procesa v praksi prevladuje tradicionalno pojmovanje poučevanja kot kopičenja in zapomnitve spoznanj, do katerih so prišli posamezniki (Marentič Požarnik, 2019). Avtorica meni, da je uveljavljanje aktualnega pristopa k pouku v obliki aktivnega poučevanja, za katerega sta značilna samostojno iskanje in razmišljanje s skupinskim dialogom ter $\mathrm{s}$ postavljanjem in preizkušanjem hipotez, gre torej za učenje, ki človeka miselno in čustveno aktivira, še vedno prepočasno. Za učinkovito učenje je pomembno, da vzgojitelji zagotavljamo pozitivno, varno in ustvarjalno okolje, v katerem je veliko raznolikih praktičnih vsebin (Retar, Plevnik, Hozjan in Kolar, 2014). Sodobni vzgojitelji na področju gibalnih/športnih dejavnosti se osredotočamo in zavzemamo za razumevanje poučevanja kot proaktivnega, ustvarjalnega in na praksi temelječega spodbujanja gibalnega razvoja otrok z razvijanjem njihovih podedovanih gibalnih sposobnosti, učenjem kakovostnih elementarnih gibalnih vzorcev in pridobivanjem novih gibalnih izkušenj s ciljem, da postajajo otroci gibalno kompetentnejši.

Na področju gibalnega poučevanja - organiziranega procesa gibalnega učenja je učenec vključen $v$ učni proces kot integrirani posameznik $v$ celoto, ki jo samo teoretično lahko strukturiramo na podsisteme, kot so: kognitivni, konativni, senzorični, motorični, socialni itd. $V$ praksi učenec deluje povsem povezano, celostno. Njegovo delovanje ni samo seštevek vseh dejavnosti, temveč zaradi interakcij deluje sinergijsko. Gibalno učenje je psihomotorični učni proces, s katerim se kot rezultat usmerjanja, vadbe oz. izkušenj hoteno in trajno spremeni zmogljivost gibalnih spretnosti (Edwards, 2010). Trajne spremembe v gibalnem izražanju ali vedênju prispevata tako duševni (psiho) kot gibalni (motorični) sistem človeka. V praksi opuščamo tovrstno poimenovanje in ga nadomeščamo s pojmom gibalno učenje. Učni izid tovrstnega poučevanja je novo znanje in védenje o različnih gibalnih strukturah. Navzven je znanje prepoznano tako, da novo naučeno gibanje postaja dovršeno, usklajeno, tekoče, 
mehko in učinkovitejše. Vzrok je v ustvarjanju novih sinaptičnih povezav. Pridobljena gibalna izkušnja se namreč realizira kot okrepitev mednevronskih povezav (Gopnik, Meltzoff in Kuhl, 2001). V procesu gibalnega učenja učenec usvoji gibalna znanja. Le-ta opredeljujeta količina in kvaliteta gibalnih programov, ki jih obvlada posameznik, pri čemer so gibalni programi centralno vodene strukture, ki določajo neko gibanje oz. predstavo o gibanju, shranjeno v gibalnem spominu (Marinšek in Rajtmajer, 2017). Pri gibalnem razvoju otroka ločimo med samoponavljanjem gibanja in gibalnim učenjem. Vsaka ponovitev gibanja še ni gibalno učenje, je pa učenje odvisno od ustreznega ponavljanja gibanja, tako od števila ponovitev kot tudi od kakovosti izvedbe.

V zgodnjem otroštvu razvoj temelji na izboljšanju percepcije kot zaznave in organizacije čutnih zaznav in gibalnih odzivov - hotene dejavnosti skeletnih mišic. Izboljšanje je posledica rasti, zorenja in lastnih izkušenj, kar prepoznamo v kakovostnejšem gibanju otroka.

\section{MOŠKI NASPROTI ŽENSKIM ŠPORTOM?}

Preseganje stereotipne delitve na moške in ženske športe ter razbijanje mitov, da imajo deklice manj ambicij v športu ali pa da imajo slabše razvite gibalne sposobnosti, sta še vedno družbeno nezaželjena. $V$ otroštvu imajo tako dečki kot deklice enako mero ambicioznosti na področju gibanja (razporeditev je skladna z Gaussovo krivuljo) , ki pa se zmanjšuje ali zvišuje glede na okolje, v katerem se otrok gibalno izraža. Športna ambicioznost ali, bolje, radovednost tako ni značajska značilnost, ampak lastnost, ki jo spodbujajo ali hromijo interakcije s starši, vrstniki, vzgojitelji, s katerimi se otroci vsakodnevno srečujejo, zato je priporočljivo, da jo vzgojitelji spodbujamo. Prav tako je smiselno opuščati delitve gibalne/športne aktivnosti na ženske ali moške.

\section{OPREDELITEV POJMOV DELOVNE KOMPETENCE, GIBALNE SPOSOBNOSTI IN GIBALNE KOMPETENCE}

Za razumevanje in določanje gibalnih kompetenc, ki naj bi jih imeli, če želimo uspešno opraviti gibalno storitev, moramo razumeti osnovne sestavine kompetenc, ki z medsebojnim sovplivanjem in upoštevajoč družbeni kontekst tvorijo kompetence posameznika. 
To so na področju gibanja najpogosteje: gibalno znanje, gibalne sposobnosti, osebne lastnosti in motivacija. Delovne kompetence, ki nas poklicno opredeljujejo in so na izobraževalnem trgu dela regulirane z zakonom, pa lahko predstavimo kot zmožnost uporabe znanja, sposobnosti, osebnostnih lastnosti, izkušenj in motivacij tako, da na svojstven način učinkovito in gospodarno uresničimo zastavljene delovne cilje ter dosežemo pričakovane učno-vzgojne izide (Retar, Plevnik in Kolar, 2013).

V nadaljevanju (preglednica 1) prikazujemo teoretični avtorski model strukture delovnih kompetenc vzgojiteljev, ki so zaželene na delovnem področju gibalnega poučevanja v zgodnjem otroštvu (Retar in Lepičnik Vodopivec, 2017).

Preglednica 1: Teoretični model strukture delovnih kompetenc inovativnega gibalnega poučevanja (Retar in Lepičnik Vodopivec, 2017)

\begin{tabular}{|c|c|c|c|c|}
\hline \multicolumn{5}{|c|}{ Področja generičnih kompetenc } \\
\hline $\begin{array}{l}\text { Komunikacija in } \\
\text { odnosi }\end{array}$ & $\begin{array}{l}\text { Učinkovito } \\
\text { poučevanje }\end{array}$ & $\begin{array}{l}\text { Organizacija in } \\
\text { vodenje }\end{array}$ & $\begin{array}{l}\text { Sodelovanje } \\
\text { z delovnim } \\
\text { in družbenim } \\
\text { okoljem }\end{array}$ & $\begin{array}{l}\text { Profesionalni } \\
\text { razvoj }\end{array}$ \\
\hline \multicolumn{5}{|c|}{ Struktura specifičnih kompetenc } \\
\hline $\begin{array}{l}\text { Učinkovito } \\
\text { komuniciranje } \\
\text { z otroki na } \\
\text { področju } \\
\text { gibanja }\end{array}$ & $\begin{array}{l}\text { Razvijanje } \\
\text { strategij za } \\
\text { motiviranje otrok na } \\
\text { področju gibanja }\end{array}$ & $\begin{array}{l}\text { Prepoznavanje } \\
\text { gibalnih } \\
\text { potreb in } \\
\text { pričakovanj } \\
\text { otrok ter } \\
\text { njihovo } \\
\text { uresničevanje }\end{array}$ & $\begin{array}{l}\text { Sodelovanje } \\
\text { s starši otrok } \\
\text { in z drugimi } \\
\text { osebami, } \\
\text { odgovornimi } \\
\text { za otroke }\end{array}$ & $\begin{array}{l}\text { Prenašanje in } \\
\text { uvajanje } \\
\text { primerov } \\
\text { dobrih praks v } \\
\text { svoje delo na } \\
\text { področju } \\
\text { gibanja }\end{array}$ \\
\hline $\begin{array}{l}\text { Oblikovanje } \\
\text { varnega, } \\
\text { prijaznega } \\
\text { in všečnega } \\
\text { učnega okolja } \\
\text { na področju } \\
\text { gibanja }\end{array}$ & $\begin{array}{l}\text { Ustvarjalno } \\
\text { izbiranje didaktičnih } \\
\text { pripomočkov na } \\
\text { področju gibanja }\end{array}$ & $\begin{array}{l}\text { Prepoznavanje } \\
\text { gibalno } \\
\text { nadarjenih } \\
\text { otrok in } \\
\text { prilagajanje } \\
\text { njihovim } \\
\text { posebnostim }\end{array}$ & $\begin{array}{l}\text { Sodelovanje } \\
\text { s športnimi } \\
\text { strokovnjaki } \\
\text { zunaj vrtca }\end{array}$ & $\begin{array}{l}\text { Vseživljenjsko } \\
\text { učenje na } \\
\text { predmetnem } \\
\text { področju }\end{array}$ \\
\hline $\begin{array}{l}\text { Spodbujanje } \\
\text { in smotrno } \\
\text { popravljanje } \\
\text { ključnih napak } \\
\text { pri gibalnem } \\
\text { učenju }\end{array}$ & $\begin{array}{l}\text { Učinkovito } \\
\text { razvijanje gibalnih } \\
\text { sposobnosti otrok, } \\
\text { kot npr. ravnotežje, } \\
\text { moč, hitrost, } \\
\text { koordinacija itd., ter } \\
\text { gibalnih vzorcev }\end{array}$ & $\begin{array}{l}\text { Razvijanje } \\
\text { učinkovitih } \\
\text { učnih oblik } \\
\text { in metod } \\
\text { gibalnega } \\
\text { poučevanja }\end{array}$ & & $\begin{array}{l}\text { Ukvarjanje s } \\
\text { športom in/ } \\
\text { ali športno } \\
\text { rekreacijo }\end{array}$ \\
\hline
\end{tabular}


V raziskavi modela vseživljenjskega poučevanja - profesionalnega razvoja (Retar in Lepičnik Vodopivec, 2017), kjer se je preverjalo, kje vzgojitelji pridobivajo kompetence in kako kakovostno je pridobivanje le-teh, anketiranci navajajo (preglednica 2), da so ključne kompetence zelo uspešno pridobili in razvili predvsem s prakso pri delu v vrtcu (33\%), s formalnim izobraževanjem (22 $\%)$, z neformalnim izobraževanjem (22 \%), s sodelovanjem v projektih (14\%) in s prakso v športu (21\%).

Preglednica 2: Kje in kako uspešno so vzgojitelji razvijali svoje delovne kompetence za naloge na področju gibanja (Retar in Lepičnik Vodopivec, 2017)

\begin{tabular}{lccccc}
\hline $\begin{array}{l}\text { Kje vzgojitelji razvijajo } \\
\text { delovne kompetence } \\
\text { za naloge na področju } \\
\text { gibanja }\end{array}$ & $\begin{array}{l}\text { Kako vzgojitelji razvijajo delovne kompetence za } \\
\text { naloge na področju gibanja }\end{array}$ & & & \\
\hline & Neuspešno & $\begin{array}{c}\text { Manj } \\
\text { uspešno }\end{array}$ & $\begin{array}{c}\text { Nekoliko } \\
\text { uspešno }\end{array}$ & Uspešno & $\begin{array}{c}\text { Precej } \\
\text { uspešno }\end{array}$ \\
\hline $\begin{array}{l}\text { S prakso pri delu v vrtcu } \\
\text { S formalnim }\end{array}$ & $0 \%$ & $2 \%$ & $10 \%$ & $55 \%$ & $33 \%$ \\
izobraževanjem & $1 \%$ & $4 \%$ & $21 \%$ & $52 \%$ & $22 \%$ \\
$\begin{array}{l}\text { Z neformalnim } \\
\text { izobraževanjem }\end{array}$ & $1 \%$ & $3 \%$ & $22 \%$ & $52 \%$ & $22 \%$ \\
$\begin{array}{l}\text { S sodelovanjem } \\
\text { v projektih }\end{array}$ & $5 \%$ & $14 \%$ & $26 \%$ & $41 \%$ & $14 \%$ \\
\hline S prakso v športu & $4 \%$ & $9 \%$ & $22 \%$ & $44 \%$ & $21 \%$
\end{tabular}

Pri delu z otroki je pomembna kompetentnost vzgojiteljev, ki se odraža v uporabi učinkovitih pedagoških strategij, taktik in pristopov. Sodobno vseživljenjsko učenje temelji na razvijanju in poglabljanju ključnih kompetenc. V teoriji zasledimo, da nekateri avtorji poudarjajo odvisnost razumevanja pojma kompetence od časa in prostora ter navajajo, npr. Laval (2005), da so kompetence zaznamovane zlasti s kulturo, politiko in z ekonomijo ter so vselej del družbenega konteksta. Družbene, politične, okoljske in gospodarske razmere družbe znanja so danes turbulentne in se odražajo tudi v vzgojno-izobraževalnem prostoru. Šola postaja podjetje (Laval, 2005), ki povzema poslovne modele in prakse neoliberalnega kapitalizma, zato moramo vzgojitelji skrbno presojati, katere poslovne pristope je koristno prevzemati in jih umeščati v poučevanje ter katere je treba odločno zavrniti, ker škodijo otrokom na poti gibalnega odraščanja. 
Raziskovalci gibalnega poučevanja so se doslej osredotočili predvsem na merjenje telesne dejavnosti, pri čemer $v$ ospredje niso postavljali gibalnega poučevanja kot celostnega procesa, temveč predvsem njegov gibalni izid - rezultat. Pri tem so zaobšli celostni pristop, še posebej pa dejstvo, da je za kakovostno razumevanje gibanja $v$ zgodnjem otroštvu nujno poznavanje zakonitosti gibalnega poučevanja zlasti glede pozitivnega vpliva na razvoj gibalnih sposobnosti ter oblikovanja kakovostnih gibalnih vzorcev in programov.

\section{GIBALNE SPOSOBNOSTI KOT PREDMET ZGODNJEGA GIBALNEGA POUČEVANJA}

Dedno pogojene in skozi sistem gibalnega poučevanja razvite temeljne gibalne sposobnosti so temelj za otrokovo nadaljnje prihodnje gibanje in dejavni življenjski slog (Stodden idr., 2008). Sposobnosti so človeku naravno dane, so elementi, ki opredeljujejo človekov videz; spretnosti pa vključujejo z učenjem pridobljena znanja. Gibalne sposobnosti delimo na pridobljene in prirojene. Z rojstvom podedujemo določene sposobnosti, ki se bodo ob normalni rasti razvile, z gibalnim učenjem in/ali ponavljajočo vadbo pa se lahko razvitost tudi preseže (Pistotnik, 2011). Gibalne sposobnosti prepoznavamo kot prirojene in razvite možnosti, ki posamezniku omogočajo učinkovito izvedbo gibalnih nalog. So merljive in na njihovi osnovi lahko ločimo razlike $v$ uspešnosti izvedbe določene gibalne naloge med dvema subjektoma pri enakih pogojih, znanju in motivaciji (Videmšek in Pišot, 2007). Gibalne sposobnosti so, tako kot druge človekove sposobnosti, prirojene, v določeni meri pa tudi pridobljene. Raziskave so pokazale, da so genetski dejavniki odločilni (Sheridan, Sharma in Cockerill, 2008; Haywood, Robertson in Getchell, 2012), vendar so pomembni tudi okoljski dejavniki, in prav to biološko dejstvo nam osmišlja ter omogoča uspešnost zgodnjega gibalnega poučevanja.

Otroci v zgodnjem otroštvu razvijajo gibalne sposobnosti in spoznavajo temeljne gibalne spretnosti, ki jih poimenujemo naravne oblike gibanja ali elementarni gibalni vzorci. Tuji avtorji (Haywood idr., 2012) uporabljajo poimenovanje »fundamental motor skills«. Različnim opredelitvam je skupno, da gre za opis temeljnih gibalnih kompetenc, ki omogočajo tako zavestno obvladovanje gibanja telesa, npr. plazenje, plezanje, tek, skok, preskok, kotaljenje itd., kot tudi zavestno obvladovanje in nadziranje predmetov, npr. met, lovljenje, odbijanje, vodenje žoge ali drugih predmetov. Kombinacija obvladovanja te- 
lesa in nadzora predmetov tvori sistem temeljnih gibalnih spretnosti, ki se lahko najučinkoviteje in najkakovostneje razvijajo samo v zgodnjem otroštvu.

\section{GIBALNE KOMPETENCE}

Gibalne kompetence so zmožnost, da z gibalnimi sposobnostmi, znanjem, osebnostnimi lastnostmi in motivacijo učinkovito izvedemo pričakovano gibalno dejavnost. Znanje je, najširše gledano (Svetlik in Pavlin, 2004), v kontekst postavljena informacija, ki je opredeljena z izkušnjami, resnico, s presojo, z intuicijo in vrednotami ter omogoča sprejemanje novih situacij in sprememb. Kompetence se povezujejo z znanjem, zlasti z vidika njegove uporabe. Gibalne sposobnosti so tiste, ki so odgovorne za kakovostno in učinkovito izvedbo gibalnih akcij ter omogočajo človekovo gibanje. Motivacija pri tem povzroča in usmerja naše delovanje. Po Kohontu (2005) obsega mnoga gibala našega vedenja: potrebe, nagone, motive, želje, cilje, vrednote, ideale, interese in voljo. Nagoni in potrebe nas spodbujajo ter ženejo $v$ vedenje, cilji, ideali in vrednote pa nam pomagajo izbrati način, kako bomo potrebe zadovoljili. $V$ izvedbo preproste ali zelo zapletene gibalne naloge je treba vložiti veliko energije - biološko gledano je gibanje hoteno sprožen prehod kemične energije v mehansko, zato je motivacija pri gibanju v ospredju.

V strokovni literaturi se opredelitve gibalnih kompetenc razlikujejo, skupen jim je le pojem gibanje. Gibalno kompetenco lahko pojmujemo kot posameznikovo izvirno in neponovljivo zmožnost gibalne učinkovitosti, ki je odločilna tako za proces učenja kot izvajanje gibalnih spretnosti.

V pedagoškem procesu gibalne/športne vzgoje moramo upoštevati številne razvojne posebnosti otroka. Za predšolskega otroka je namreč značilno, da njegovo skeletno mišičje še ni v celoti diferencirano, za njegov srčno-žilni sistem je značilna višja frekvenca srca, za dihalni sistem pa večja frekvenca dihanja kot pri odraslem, medtem ko je za otrokov živčni sistem značilno, da mielinizacija še ni zaključena in še ni popolnoma diferenciran. Ker na otrokov razvoj lahko pomembno vplivajo tako biološki, sociološki, demografski, psihološki in okoljski kot tudi drugi dejavniki, je za razvijanje gibalnih kompetenc primeren in učinkovit samo celostni pristop, ki od vzgojitelja zahteva nabor specifičnih delovnih kompetenc, s katerimi bo lahko kos tej zahtevni nalogi. 


\section{NEVROLOŠKE OSNOVE DELOVANJA GIBALNEGA SISTEMA KOT PODLAGA ZA GIBALNO UČENJE IN POUČEVANJE}

Poznavanje razvoja in delovanja možganov in živčno-mišičnega sistema nam $v$ praksi pomaga pri načrtovanju in izvedbi gibalnih učnih vsebin. Na nevroznanosti temelječe zgodnje gibalno poučevanje je namreč učinkovitejše, kakovostnejše in otrokom prijaznejše ter pričakovani učni izzivi lažje dosegljivi. Poleg tega lahko s primerjanjem doseganja mejnikov razvoja hitreje opazimo morebitna večja ali manjša odstopanja otrok od povprečja oz. otrokove pomanjkljivosti $v$ gibalnem razvoju, ki jih $s$ pomočjo določenih (specializiranih) gibalnih dejavnosti in nalog $v$ predšolskem obdobju lahko odpravimo do te mere, da so obvladljivi ali pa celo izzvenijo.

Ker razumevanje gibalnega poučevanja temelji na nevrofiziološkem in psihološkem delovanju, lahko zapleten proces izvedbe gibanja najpregledneje razložimo na podlagi biološkega delovanja organizma.

Gibanje, poenostavljeno predstavljeno, se prične z receptorskim sistemom, ki zazna informacije in dražljaje iz zunanjega in notranjega okolja. Podatki se prenesejo na živčne celice, ki preko številnih mednevronskih povezav predajo informacije $v$ centralni živčni sistem do ključnih možganskih centrov (primarno motorično področje, ki je odgovorno za izvedbo te naloge).

Centri nato informacij obdelajo in oblikujejo ustrezen gibalni odgovor ali ukaz, ki povzroči izvedbo gibanja. Na podlagi izvedenega gibanja centralni živčni sistem naredi primerjavo med želenim in dejansko izvedenim gibanjem. To je začetek gibalnega učenja, $v$ katerem učeči prepozna in uporabi povratne informacije za pravilno, lažjo, hitrejšo ali natančnejšo ponovitev gibanja.

Živčni sistem tvorijo nevroni, ki jih delimo na senzorične nevrone (aferentna živčna pot), ki se odzivajo na zunanji dražljaj (svetloba, zvok, drseča podlaga ...), motorične nevrone (eferentna živčna pot), ki prenašajo sporočila mišicam, organom in žlezam, ter povezovalne/vmesne nevrone, ki prenašajo in integrirajo informacije med drugimi nevroni.

Živčne celice zato lahko delimo na aferentne, ki prenašajo informacije dražljaje iz periferega okolja $v$ centralni živčni sistem, in eferentne celice, ki prenašajo informacije iz centralnega živčnega sistema $v$ periferni sitem kot gibalni odgovor na dražljaje, ter integracijske, ki oba sistema povezujejo, da usklajeno delujeta.

Živčni sistem delimo na centralni (možgani in hrbtenjača) in periferni živčni sistem (to je 43 parov živcev, katerih naloga je, da povezujejo čutila, mišice in organe s centralnim živčnim sistemom). Glede na delovanje sistema živčevje delimo na somatsko in vegetativno. Somatsko živčevje deluje pod vplivom 
naše volje in skrbi za delovanje skeletnih mišic, omogoča hojo, delo z rokami, komunikacijo ... Vegetativno živčevje deluje neodvisno od naše volje in uravnava delovanje notranjih organov (srca, dihal, prebavil ipd.), endokrilnih žlez in vzdržuje notranje okolje (Štiblar-Martinčič, Cör, Cvetko, Marš in Legan, 2012).

Možgani so središče živčnega sistema, v katerem se zbirajo sporočila preko čutilnih živcev iz okolja, se nato ovrednotijo in sprejemajo odločitve ter se preko gibalnih živcev sporoča ciljnim mišičnim celicam, kako naj se odzovejo. Sestavljeni so iz možganskih celic ali nevronov, ki nam omogočajo, da mislimo, se premikamo in čutimo. So celice, ki obdelujejo in prenašajo informacije. Sestavljeni so iz sinaps, ki prve zaznajo informacijo oz. elektrokemijski impulz in ga prenesejo v dendrit, ki informacijo pošlje celičnemu telesu. Celično jedro prejme informacijo in jo posreduje po aksonu naprej do drugega celičnega jedra oz. sinapse. Postopek se ponavlja in nadaljuje, dokler informacija ne pride do »pravega« dela možganov, ki jo razume in poda ustrezen odziv ali pa to informacijo skladišči oz. jo izbriše, ko je prepozna kot nepomembno. Možgani tehtajo 1,4 kg, desna stran povezuje levo in obratno, osnovni gradniki živčnega sistema so nevroni. V možganih je lahko do 100 milijard nevronov, ki se povezujejo in sporazumevajo z elektrokemičnimi signali preko povezave, imenovane sinapsa. Vsak nevron se lahko povezuje z do 1.000 drugimi nevroni in lahko vsako sekundo pošlje do 100 sporočil, ki potujejo s 400 km na uro! Več sinaps pomeni več znanja, tudi gibalnega, kajti iz okolja senzorični sistemi zaznajo in zajamejo podatke ter jih posredujejo v osrednje živčevje. Namen podatkov je vzpostavljanje nadzora gibalnih vzorcev, ki omogočijo uspešno prilagajanje na spremembe v okolju prek eferentnih sistemov (somatičnega, vegetativnega, hormonskega in imunskega). Najvidnejša oblika tovrstnega prilagajanja je gibanje, ki ga ustvarjajo skeletne mišice in ga nadzirajo gibalni sistemi somatskega živčevja. Končni rezultat nadzora je pretvorba vzorcev živčnega vzburjenja v mehansko energijo mišične kontrakcije, ki ob posredovanju gibalnega sistema (mišičje, sklepi, tetive, okostje) omogoča gibanje. V procesu gibalnega učenja še »mislimo« gibanje, npr. ko se učimo voziti kolo, kasneje, ko usvojimo gibalni program, pa je gibanje izvedeno avtomatizirano - preprosto kolesarimo.

\section{KAKO DELUJEJO MOŽGANI V POVEZAVI Z GIBANJEM?}

Bistvo delovanja velikih možganov je v prevajanju in pošiljanju živčnih dražljajev, s katerimi doživljamo svet, se usklajeno gibamo, mislimo, ustvarjamo in 
gradimo zavedanje o sebi. Veliki možgani so sestavljeni iz dveh hemisfer, ki ju gradita sivina in belina. Med seboj sta ločeni s prečnikom (vzdolžno brazdo), ki obe hemisferi tudi povezuje s svežnjem vlaken in tako omogoča komuniciranje med njima. Vsaka možganska hemisfera je odgovorna za določene miselne procese, obdelavo podatkov in razvoj določenih kompetenc človeških spretnosti (Štiblar-Martinčič idr., 2008).

Leva možganska hemisfera je analitična in specializirana za zahtevnejše funkcije, kot so jezik, govor, pisanje in branje, logično in abstraktno mišljenje, spomin, zanima jo predvsem vprašanje, kako (zavest), medtem ko se desna možganska hemisfera sprašuje, zakaj (podzavest). Desna polovica prevzema odgovornost za vidnoprostorske naloge in omogoča celosten pregled nad situacijo, dogodke med seboj povezuje, razmišljanje pa podpre z dejanskimi izkušnjami in s »slikami«. Večina funkcij je nadzorovana iz nasprotne hemisfere, kar pomeni, da dražljaje iz ene strani telesa sprejema in nadzoruje hemisfera na nasprotni strani. Če povežemo ta dejstva s prakso, to pomeni, da je pomembno, da otroka spodbujamo $k$ izvedbi gibalne naloge še $z$ nedominantnim delom telesa (roko, nogo, ko se princip dominantnosti pri približno petih letih razvije), saj s tem otrok krepi medsebojno (živčno) povezanost obeh hemisfer.

Med možganskima hemisferama ležijo srednji možgani/medmožgani oz. diencefalon, katerega glavne naloge obsegajo uravnavanje telesne temperature, delovanje srca in ožilja ter imajo povezovalno vlogo med vegetativnim, somatskim in endokrilnim sistemom. Sestavlja ga več delov: eden je talamus, ki je eden od osrednjih komunikacijskih centrov v možganih. Zajema mnogo jeder, ki imajo močno dvosmerno povezavo z možgansko skorjo. Sem pritekajo informacije iz čutil - kar vidimo, slišimo, okusimo in otipamo. Talamus nato te informacije pošlje ustreznim predelom korteksa. Drugi del je hipotalamus, ki uravnava delovanje vegetativnega živčevja - glavna endokrilna žleza hipofiza. Kadar nas zebe, smo utrujeni ali lačni, informacije iz telesa potujejo do hipotalamusa, ki jih nato posreduje ustreznemu predelu korteksa. Njegova osrednja naloga je nadzor notranjega okolja - homeostaze, ki je tudi zaradi sodobnega stresnega načina življenja pogosto porušena. Kakovostne in posamezniku prilagojene programske vsebine gibanja lahko prispevajo k vzpostavljanju homeostaze. Hipotalamus je del limbičnega sistema, ki uravnava nagonsko vedenje organizma (žeja, lakota, spolnost, jeza ipd.). Limbični sistem je ime za več med seboj povezanih predelov možganov, ki uravnavajo čustva in spomin. Glavna centra za spomin in čustva sta hipokampus in amigdala. Hipokampus je ključen za oblikovanje spominov, saj vsako doživetje oblikuje s čutili (Štiblar-Martinčič idr., 2008). Amigdala pa je ključni center za shranjevanje čustvenih spominov in iskanje strategij preživetja, saj se 
aktivira ob zaznavi grožnje ali nevarnosti in telo prisili na boj ali beg, zato je pri gibalnem poučevanju pomembno ustvarjati ugodno učno okolje, da se zaradi strahu ne sproži delovanje amigdale, ki zavira kakovostno hoteno gibanje. Možganski hemisferi obdaja možganska skorja, ki je po funkcionalnosti razdeljena na senzorično, motorično in asociacijsko skorjo. Motorični predeli skorje so odgovorni za načrtovanje gibanja in usklajeno delovanje skeletnih mišic s strukturo režnjev.

Čelni reženj oz. predfrontalni korteks je visoko razvit predel, ki nam omogoča zasnovati zapletene načrte, predvidevati in se odločati. Sodeluje v načrtovanju, pobudah in hotenem nadzoru gibanja. Tu se nahaja primarna motorična skorja, ki sodeluje pri načrtovanju strukturiranega, kompleksnega in zelo zahtevnega gibanja telesa.

Temenski, premotorni oz. gibalni korteks sodeluje v zaznavanju ter občutenju in nadzorovanju telesnih delov. Vsebuje mnogo senzoričnih predelov, kot je vidni asociacijski predel, potreben za prepoznavanje objektov. Integrira tudi informacije iz različnih senzoričnih predelov, da omogoči usklajenost (npr. združitev videza in zvoka; oko - roka). Odgovoren je za načrtovanje gibanja in usklajeno delovanje skeletnih mišic.

Senčni oz. temporalni teženj je pomemben predel za poslušanje, jezik in spomin.

Zatilni oz. okcipitalni reženj zajema vidno skorjo in primarni vidni predel, ki sodeluje $v$ analizi vidnih dražljajev.

V zadnjem delu lobanje se nahajajo možgansko deblo in mali možgani, katerih glavna funkcija je, da povezujejo možgane s hrbtenjačo, z velikimi možgani, možganskim deblom in jedri organa za ravnotežje. Odgovorni so za usklajeno telesno gibanje, kontrolo drže, ohranjanje ravnotežja in za nekatere oblike gibanja. Možgansko deblo predstavlja vrh hrbtenjače, tvori številna motorična in senzorična jedra možganskih živcev, skozi katera potekajo motorične in senzorične povezave glavnega dela telesa in možganov, nadzira srčni utrip, dihanje in druge avtomatične funkcije. Podaljša se v hrbtenjačo, ki leži v hrbteničnem kanalu in omogoča refleksne odgovore na dražljaj (Štiblar-Martinčič idr., 2008).

\section{NADZOR GIBANJA}

Nadzor lahko glede na trajanje giba razdelimo na tonični nadzor vzdrževanja drže telesa ali udov in fazični nadzor hitrejših gibov. Gibe delimo v tri prekrivajoče se kategorije (Štrucl, 1999): 
- refleksne gibe (npr. umaknitveni refleks, požiralni refleks, refleks kašljanja itd.): najenostavnejši, hitri, stereotipni gibi, ki so najmanj pod vplivom naše volje;

- ritmične gibe (npr. stereotipna hoja, prežvekovanje, dihalni gibi): avtomatizirani, stereotipni, izmenjujoči se gibi. Kadar se sprožijo, sprožimo in ustavimo jih zavestno, hoteno, potekajo precej neodvisno od volje, avtomatično in jih vzdržujejo posebna nevronska vezja $v$ možganskem deblu ali hrbtenjači;

- hotene, velike zapletenejše gibe (npr. plavanje, vožnja kolesa, smučanje, rolanje itd.), ki zahtevajo udeležbo višjih, kortikalnih sistemov. Razen tega so usmerjeni k nekemu (hotenemu) cilju in so odvisni od poučevanja ponavljanja ustreznih gibov, ki omogoči avtomatizacijo.

Živčne strukture nadzirajo skeletne mišice in so razmeščene po celotnem osrednjem živčevju. Urejene so po načelu nadrejenosti:

- hrbtenjača (spodnji motorični nevroni);

- možgansko deblo;

- mali možgani;

- bazalni gangliji;

- motorični predel možganske skorje (zgornji motorični nevroni).

Hrbtenjača predstavlja najnižjo raven motoričnega nadzora, ki omogoča izzivanje spinalnih refleksov in ritmičnih gibov. Možgansko deblo je naslednja raven nadzora in omogoča nadzor drže telesa ter gibov oči in glave. Najvišjo raven motoričnega nadzora omogoča možganska skorja. Glavni refleksi za vzdrževanje drže v možganskem deblu so vestibulospinalni refleks (prerazporeditev antigravitacijskega tonusa pri premikih glave), tonični vratni refleksi (prerazporeditev antigravitacijskega tonusa pri fleksiji v vratu) in refleksi izravnavanja drže.

Primarna motorična možganska skorja in dve sekundarni, to sta premotorična in suplementarna motorična skorja, nadzorujejo kompleksne hotene gibe. Motorična skorja prejema podatke iz posteriornih parietalnih predelov in prefrontalnega asociacijskega predela možganske skorje, ki so pomembni za usmerjenost, koordinacijo in načrtovanje sekvenc gibov (Štrucl, 1999). Poleg treh hierarhičnih ravni motorične kontrole, to je spinalnega nadzora, nadzora možganskega debla in kortikalnega nadzora, se v shemo motoričnega nadzora vključujeta še dve masivni strukturi: bazalni gangliji in mali možgani, ki predstavljajo (prek talamusa povratno povezani s korteksom velikih možganov) pomemben modulacijski sistem za nadzor gibanja. Na vseh ravneh mo- 
toričnega nadzora je ključnega pomena senzorična povratna informacija. Mali možgani prejemajo tudi eferentno kopijo: informacijo o motoričnem povelju, kar omogoča sprotno primerjavo povelja in izvedbe gibov ter popravljanje napak (Štrucl, 1999), kar je pomembno zlasti pri procesu popravljanja napak pri gibalnem učenju. Prav to nevrobiološko značilnost delovanja možganov s pridom uporabljamo pri gibalnem učenju.

Na področju gibanja imajo mali možgani pomembno vlogo pri ohranjanju ravnotežja in uravnavanju drže telesa ter usklajevanju gibov. Delujejo tako, da primerjajo motorična povelja za nameravane gibe s povratnimi sporočili o dejanskem izvrševanju gibov. Tako lahko preko notranjih in zunanjih povratnih informacij sproti popravljajo napake v potekajočih gibih. Prav tako lahko (npr. pri hitrejših gibih, kjer sprotno popravljanje ni mogoče) modificirajo centralne motorične programe tako, da gibi potekajo natančneje, gladkeje in hitreje. To se zgodi v procesu gibalnega poučevanja. Mali možgani imajo tipično trodelno zgradbo glede na filogenetsko starost, pritok in odtok informacij (Štru$\mathrm{cl}$, 1999). Bazalni gangliji so bolj kot v izvrševanje motorike (za razliko od malih možganov) vključeni $v$ višje kognitivne funkcije motorične kontrole (načrtovanje, izbira strategij zapletenih gibov glede na informacije iz okolja) (Štrucl, 1999). 


\section{II. \\ GIBALNI RAZVOJ OTROKA}





\section{GIBALNI RAZVOJ OTROKA: TEMELJNI POJMI}

\section{OSNOVE TEORIJE INTEGRIRANEGA RAZVOJA OTROKA}

Zgodnje otroštvo predstavlja za otroka najpomembnejše obdobje. Takrat poteka njegov najintenzivnejši razvoj na vseh področjih. Otrok se v tem obdobju razvija celostno. Temeljna področja, na katerih zaznamo najintenzivnejši in najhitrejši razvoj, predstavljajo telesni, gibalni, spoznavni, čustveni in socialni razvoj (Cemič, 1997; Videmšek in Pišot 2007).

Otrokov razvoj je celostni proces, ki poteka na različnih področjih od rojstva do smrti in zajema spremembe $v$ kvantiteti in kvaliteti organskih sistemov ter celotnega psihosomatskega sistema. Temeljna področja razvoja se med seboj prepletajo in potekajo na telesni, intelektualni, čustveno-osebnostni in socialni ravni v soodvisnosti od temeljnih dejavnikov otrokovega razvoja. To so: dednost, okolje in lastna samodejavnost posameznika.

Dednostni dejavniki so prirojene biološke osnove in se prenašajo s starša na otroka z genetskim prenosom. Nekateri geni, kot npr. tisti v povezavi z delovanjem telesa, so skupni vsem ljudem, drugi vplivajo na značilnosti, po katerih se ljudje med seboj razlikujejo, npr. hitrost. Dedna zasnova namreč določa, kolikšen delež mišične mase bodo predstavljala hitra in koliko počasna mišična vlakna. 


\section{TELESNI RAZVOJ}

Genotip je posameznikova genetska konstitucija, ki je kombinacija alelov in vsebuje 23 parov kromosomov, ki poleg okoljskih vplivov opredeljujejo posameznika. Rast predstavlja dedno pogojeno komponento razvoja, na katero imamo relativni vpliv - kaže se $v$ telesnem razvoju otroka. $V$ stopnjo zorenja so vključene kakovostne spremembe v otrokovem razvoju, ki predstavljajo filogenetske funkcije (naravne oblike gibanja). Izkušnje se kažejo ravno obratno, in sicer v razvoju ontogenetskih funkcij oz. razvijanju otrokovih potencialov na podlagi izkušenj, ki mu jih ponudi okolje (Cemič, 1997). Otrok v zgodnjem otroštvu svet doživlja in zaznava prek dražljajev, ki izhajajo iz njega samega in iz njegove okolice. Razvoj človeka poteka skladno z naravnimi zakonitostmi, če so v času razvoja optimalni okoljski pogoji. Ključna zakonitost na področju telesnega in gibalnega področja je razvoj, ki poteka v dveh smereh, in sicer v cefalokavdalni (nadzorovanje gibanja od glave do nog) in proksimodistalni smeri (nadzorovanje gibanja od hrbtenice navzven - od grobih do finih gibov). Na razvoj omenjenih področij pri otroku vplivajo štirje ključni dejavniki - rast, zorenje, izkušnje in adaptacija. Videmšek in Pišot (2007) menita, da ima poleg naštetih dejavnikov pomemben vpliv še otrokova lastna dejavnost. Povzamemo lahko, da je najučinkovitejši celosten pristop gibalnega poučevanja, ki obravnava vse ključne dejavnike in omogoča sinergijske učinke ter optimizacijo gibalnega razvoja otroka.

\section{TELESNA RAST}

Telesna rast predstavlja spremembe $v$ razsežnostih telesa in posameznih delov ter razmerij med njimi. Malina idr. (2004) jo opredeljujejo kot proces sprememb razsežnosti posameznih delov in vsega telesa, na katere pomembno vplivajo genski in okoljski dejavniki. Telesne razsežnosti opisujemo v štirih skupinah, in sicer v dolžinskih merah, prečnih merah, obsegih in kožnih gubah, združenih v sklop antropometričnih značilnosti človeka. Rast posameznih delov telesa ne poteka vedno usklajeno in enako hitro, prav tako se tudi ne konča v enakem starostnem obdobju, temveč se hitrost telesne rasti v različnih razvojnih obdobjih spreminja (Malina idr. 2004; Pišot in Planinšec, 2010). Najhitrejša rast otroka poteka $v$ prvih treh letih življenja, ko se telesna masa do prvega leta podvoji. Otroško telo se spreminja, postane vitkejše, otrok začenja pridobivati mišično maso, dečki so višji in težji od deklic. V prvih dveh letih srce svojo težo 
podvoji. Srčni utrip pri dojenčkih dosega 130 udarcev na minuto, pri otroku od drugega do šestega leta od 90 do 110, medtem ko ta pri odrasli osebi dosega od 70 do 80 udarcev na minuto. Pljuča otroka so slabše raztegljiva, dihalne poti ozke, diha s trebušno prepono. Ob rojstvu so možgani najrazvitejši organ. Glede na druge dele telesa je glava večja. Od petega do šestega leta starosti doseže živčni sistem okrog $90 \%$ končne vrednosti. V kasnejšem obdobju otroštva je telesna rast umirjena. Telesna višina se od petega do desetega leta starosti poveča povprečno za 5-6 centimetrov letno. Hitrejša rast je značilna za obdobje pred petim in po desetem letu starosti (Pišot in Planinšec, 2010; Škof, 2017). Skladno s telesno višino se otroku nekoliko počasneje povečujejo ostale telesne značilnosti. Telesna masa se $v$ tej starosti poveča za približno 2,75$4 \mathrm{~kg}$ letno (Tanner, 1978). $\mathrm{V}$ tem obdobju se spreminjajo tudi nekatera telesna razmerja, ki postajajo podobna kot pri starejših. Indeks telesne mase (ITM) v obdobju zgodnjega otroštva enakomerna pada, med šestim in sedmim letom starosti pa se začne postopno povečevati. Spreminjati se začnejo tudi nekatera druga razmerja (sedna višina in dolžina nog, širina ramen $v$ primerjavi s širino kolkov) (Malina idr., 2004). Prav tako se $v$ razvoju spreminja telesna sestava. Delež mišičevja je v zgodnjem otroštvu enakomeren in predstavlja približno $25 \%$ celotne telesne mase (Eckert, 1987). Dečki imajo nekaj več mišične in kostne mase kot deklice. Delež telesnega maščevja se $v$ otroštvu enakomerno zmanjšuje in s $25 \%$ v drugem letu pade na približno $15 \%$ v sedmem letu starosti. Deklice imajo nekoliko večji delež telesnega maščevja od dečkov, razlika se z naraščanjem starosti postopno povečuje (Malina idr., 2004).

\section{SPOZNAVNI RAZVOJ}

Spoznavni razvoj vključuje razvoj in krepitev miselnih, spoznavnih procesov: zaznavanje, predstavljanje, presojanje, sklepanje, spomin, govor, reševanje problemov, ki omogočajo analiziranje, odločanje in učenje (Marjanovič Umek in Zupančič, 2004). Otrok jih uporablja pri pridobivanju znanja, hkrati pa mu omogočajo, da se zaveda okolja, ki ga obdaja (Marjanovič Umek in Zupančič, 2004). Na spoznavni razvoj vplivajo različni dejavniki: biološko zorenje, izkušnje iz okolja, lastna dejavnost. Spoznavni razvoj ni neodvisen proces, temveč poteka $v$ tesni povezanosti s telesnim, z gibalnim, s čustvenim in socialnim razvojem. Piaget je razvil teorijo kognitivnega razvoja, ki je sestavljena iz štirih stopenj. 
V prvi, poimenovani senzomotorična stopnja ( $v$ prvih dveh letih otrokovega življenja), se prične razvoj refleksov, primarnih, sekundarnih in terciarnih krožnih reakcij ter njihovo usklajevanje. Sledi predoperativna stopnja (od drugega do šestega/sedmega leta), ki vključuje začetke simbolnih funkcij z značilnostmi egocentrizma, animizma, artificializma, finalizma, centrizma in realizma, ireverzibilnostjo mišljenja, miselno konzervacijo količin, razumevanjem razvrščanja in urejanja, ampak brez logičnega mišljenja. Tretje obdobje (od šestega/sedmega do enajstega leta starosti) že vsebuje konkretnologične operacije in vključuje razumevanje stvari, ki jih na predoperativni stopnji otrok še ni zmogel dojeti s pomočjo konkretnega materiala in situacij. Šele zadnja stopnja formalnologičnih operacij (od enajstega/dvanajstega leta naprej) predstavlja nadgradnjo v primerjavi s prejšnjimi stopnjami, in sicer je otrok že sposoben uporabljati abstraktno mišljenje (Labinowicz, 2010).

\section{ČUSTVENO-SOCIALNI RAZVOJ}

Čustveni razvoj predstavlja področje otrokovega razvoja, ki se razvija že od rojstva naprej. Nanj vpliva veliko dejavnikov, kot so zorenje, učenje, izkušnje, spoznavni procesi in samodejavnost. Čustva se razvijajo od povsem osnovnih do kasneje kompleksnejših čustvenih izrazov. V zgodnjem otroštvu lahko otrokova čustva razdelimo tudi na pozitivna (veselje) in negativna (strah, jeza). Če je negativnih čustev preveč, se njihov vpliv začne kazati tudi v gibalnem, kognitivnem in socialnem razvoju (Videmšek in Pišot, 2007).

Sposobnost izražanja čustev otrok pridobi z rojstvom. Z razvojem čustva postajajo vse bolj diferencirana, narašča sposobnost njihovega izražanja ter obvladovanja in prepoznavanja čustev pri drugih. Z razvojem se spreminjata moč doživljanja in izražanja čustev, predvsem pa se v zgodnjem otroštvu izpopolnjuje nadzor nad izražanjem čustev, ki postajajo vse bolj uravnovešena in socialno sprejemljiva (Pišot in Planinšec, 2010).

Otrokovo socialno okolje se po nekaj letih vse bolj seli v okolje med vrstniki v vrtcu in bivalnem okolju, vedno manj časa preživi z odraslimi. Posledično zaradi vplivov novega okolja začne razvijati nove oblike socialnih interakcij in socialne kompetence na področju sposobnosti komuniciranja, empatije in skupnega reševanja problemov, kar privede do spoznavanja pravil vedenja in razumevanja raznovrstnosti medsebojnih odnosov. 


\section{RAZVOJ GIBALNIH SPOSOBNOSTI KOT GRADNIK GIBALNEGA RAZVOJA}

Zgodnje otroštvo predstavlja temelj gibalnega razvoja, saj je otrokov organizem vplivom okolja najbolj izpostavljen prav v tem obdobju; tedaj je vpliv na maksimalni razvoj podedovanih gibalnih in funkcionalnih sposobnosti največji. Prav zato je vloga vzgojitelja pri celostni podpori gibalnega razvoja otroka, zlasti s pomočjo sistematičnega razvijanja gibalnih sposobnosti, od ravnotežja in moči do koordinacije ter drugih pojavnih oblik gibanja, neprecenljiva.

Človek se razvija v različnih razvojnih obdobjih, ki imajo svoje značilnosti in posebnosti (Marjanovič Umek in Zupančič, 2004; Malina idr., 2004). Pri tem je otrokov gibalni razvoj povsem specifičen in enkraten. Poteka na različnih ravneh, $v$ različnih razvojnih fazah in stopnjah ter $\mathrm{z}$ različno, vsakemu posamezniku prilagojeno dinamiko. Prvi gibi po rojstvu potekajo na refleksni ravni, brez zavestne kontrole, nakar jim sledijo elementarni gibalni vzorci (plazenje, lazenje, potiskanje, vlečenje, met, skok itd.). Ustrezne gibalne dejavnosti so zato $v$ predšolskem obdobju ključnega pomena za otrokov telesni, gibalni in funkcionalni razvoj ter pozitivno vplivajo na njegove spoznavne, socialne in čustvene sposobnosti ter lastnosti. Kljub znanstvenim spoznanjem o pozitivnih učinkih gibalnih/športnih dejavnosti v visoko razvitih družbah beležimo trend, da je vse manj otrok gibalno aktivnih in da jih ima vedno več prekomerno telesno težo. Slovenski sedemletniki so med državami Evropske unije zaradi debelosti celo med bolj ogroženimi (Gabrijelčič Blenkuš, 2013), kar je lahko posledica tudi nezadostne gibalne dejavnosti.

Pozitivne gibalne in tudi športne izkušnje iz otroštva se prenašajo $v$ obdobje odraslosti. Šport je model aktivnega načina življenja, zato mora vzgojitelj otroka v športne dejavnosti uvajati s pozitivnimi izkušnjami in z lastnimi zgledi. Gibalna/športna vadba mora biti za otroke varna, učinkovita, zabavna in prijetna, kar pa za vzgojitelja pri načrtovanju in vodenju varnih, učinkovitih in otrokom prijaznih gibalnih dejavnosti pomeni še dodatno odgovornost. Poleg poznavanja osnov gibalnega razvoja znotraj celostnega razvoja otroka in temeljnih zakonitosti regulacije ter poučevanja gibanja mora vzgojitelj izbrati še ustrezne pedagoške strategije in didaktične postopke za gibalno poučevanje otrok ter jih dodatno motivirati s pregledno demonstracijo, spodbujanjem, z zgodbo, s smiselnim popravljanjem, ponavljanjem in seveda tudi z lastnim zgledom.

Za boljše razumevanje so $v$ nadaljevanju predstavljena temeljna načela gibalnega razvoja (Škof, 2017): 
Načelo vzajemnega delovanja poudarja vzpostavitev urejenega odnosa med obema stranema telesa. Pogoj za to je harmonično delovanje mišic upogibalk in iztegovalk, kar omogoča vzpostavitev urejenega giba (pridobi se z vajo), posledica česar pa je somerno gibanje obeh strani telesa. Gibalne razvojne stopnje imajo svoje zaporedje. Gibalni razvoj temelji na razvoju nevroloških funkcij in sposobnosti; poteka po vnaprej določenem razvojnem vrstnem redu; vsak razvojni napredek je odvisen od razvojne stopnje prejšnjega.

Načelo nepovratnosti pojasnjuje, da odklon od načela vrstnega reda vodi do zamenjave stopenj, kar povzroča spremembe v gibalnem razvoju. Pri večjih odklonih izpada se razvoj upočasni ali se pojavijo patološki gibalni vzorci.

Načelo razvojne smeri poudarja, da gibalni razvoj poteka v točno določeni smeri, in sicer od mišic pri trupu do oddaljenejših mišic.

Načelo funkcionalne nesomernosti temelji na zavedanju obeh strani telesa, kar v otroštvu dopušča razvoj prevlade ene strani telesa. Razvoj simetrije in križanja telesne središčnice privede do razvoja ročne dominantnosti.

Motorični in senzomotorični razvoj (gibalni razvoj poteka v določenem vrstnem redu - usmerjenost k pridobivanju gibalnega vedenja).

Osnovne paradigme gibalnega razvoja:

- gibalni razvoj poteka od glave navzdol in od središča telesa navzven,

- najprej se razvijejo gibalne spretnosti,

- sledi razvoj gibalnih sposobnosti

- in gibalnih vzorcev

- ter gibalnih odzivov na reševanje gibalnih problemov.

Gibalni razvoj poteka od postopnega opuščanja refleksnih gibov v prvem letu starosti in nastanka številnih slabo diferenciranih gibov do samodejnih hotenih gibov (gibalnega nadzora). Gibalna funkcija vpliva na telesno zgradbo, zaradi česar med otroki obstaja velika raznolikost glede starosti, v kateri se pojavijo tipični razvojni mejniki (nekdo shodi pri 11, drug pa pri 13 mesecih). Gibalni razvoj se izraža v strukturnih spremembah gibalnega obnašanja v različnih obdobjih človekovega življenja. Različni avtorji (Gallahue idr., 2011; Haywood idr., 2012) utemeljujejo, da je razvoj povezan s kronološko starostjo, ni pa od nje odvisen in poteka skozi različna obdobja - razvojne stopnje, za katere je značilna skupna oblika gibalnega obnašanja, ki velja za večino otrok. Posamezne razvojne stopnje se pojavljajo v enakih starostnih obdobjih in trajajo približno enako dolgo, se pa lahko zaradi individualnih razlik posamezne razvojne stopnje pojavijo tudi v različnih starostnih obdobjih. 


\section{ZNAČILNOSTI GIBALNEGA RAZVOJA V ZGODNJEM OTROŠTVU}

Gibalni razvoj v prvih mesecih življenja predstavljajo refleksi. Vmesna stopnja med refleksi in hotenimi gibi so spontani ritmični gibi novorojenčka. Gibalni razvoj si lahko predstavljamo kot razvoj nadzorovanja hotenega gibanja. Otrok ob rojstvu glavo premika levo in desno, leže na trebuhu, začne glavo dvigovati. Do tretjega meseca lahko otrok glavo pokonci drži že samostojno, brez naše opore. V prvih sedmih mesecih se obrača okoli svoje osi - od prvega do tretjega meseca se prevrača z boka na hrbet, od petega do sedmega meseca pa se večina že samostojno obrne s hrbta na trebuh. Otroci se okoli šestega meseca začnejo plaziti in laziti. Med osmim in desetim mesecem večina že samostojno stoji, med devetim in trinajstim mesecem pa jih večina tudi shodi - najprej zelo okorno, kasneje pa že koordinirano. Pri dve leti starih otrocih se lahko pojavi tudi tek. Hoja in tek se z vidika končnega gibalnega vzorca oblikujeta med četrtim in petim letom starosti. Poleg omenjenih velikih gibov poznamo tudi drobne gibe: pincetni prijem, koordinacija oko - roka, začetek risanja in pisanja ter izbira dominantne roke. Prvi se kaže npr. pri prijemanju predmetov: $s$ celo dlanjo najprej, kasneje pa že samo z dvema prstoma. Napredek v koordinaciji oko - roka se kaže v vse večjem nadzoru drobnih gibov pri vsakdanjih opravilih (hranjenje $z$ žlico) in gibalnih dejavnostih (met žogice). Če otrok ne doseže najvišjega obdobja temeljne gibalne stopnje, obstaja možnost, da bo imel v nadaljnjem gibalnem razvoju težave (Gallahue idr., 2011).

Cemič (1997) gibalne vzorce deli v tri skupine:

- položajni gibalni vzorci (tonični refleksi): predstavljajo prve gibalne vzorce pri novorojenčku, ki praviloma izginjajo od drugega meseca do prvega leta;

- postavitveni vzorci (statični refleksi): otroku omogočajo normalno držo glave glede na položaj njegovega trupa;

- stojno-gibalni vzorci (statokinetični refleksi): telo se prilagaja novim situacijam zaradi zunanjih sil - ohranjanje ravnotežja telesa.

Opisane gibalne vzorce so raziskovalci umestili v več stopenj in podstopenj, saj njihov razvoj poteka po točno določenem zaporedju in s pričakovanimi odkloni. Rezultat predhodne stopnje je izhodišče za vzpostavitev naslednje. Razvojne faze in stopnje si sledijo v naslednjem zaporedju (preglednica 3): 


\begin{tabular}{l}
\hline 1. Refleksna gibalna stopnja \\
\hline Obdobje vkodiranja (zbiranja) informacij (traja od prenatalnega obdobja do četrtega \\
meseca) \\
\hline Obdobje dekodiranja (procesiranja) informacij (traja od četrtega meseca do prvega leta) \\
\hline 2. Začetna gibalna stopnja \\
\hline Obdobje inhibicije refleksov (primitivnih in posturalnih) (traja od rojstva do prvega leta) \\
\hline Prekontrolno obdobje (traja od prvega do drugega leta) \\
\hline 3. Temeljna gibalna stopnja \\
\hline Začetno obdobje (traja od drugega do tretjega leta) \\
\hline Osnovno obdobje (traja od četrtega do petega leta) \\
\hline Obdobje zrelosti (traja od šestega do sedmega leta) \\
\hline 4. Specializirana gibalna stopnja \\
\hline Prehodno obdobje (traja od sedmega do desetega leta) \\
\hline Obdobje prilagoditve (traja od enajstega do trinajstega leta) \\
\hline Obdobje trajne uporabnosti (traja od štirinajstega leta naprej) \\
\hline
\end{tabular}

Od rojstva do prvega leta starosti traja refleksna faza, ko še ni povsem hotenih gibov, temveč so samo refleksni, ki pa postopno ugašajo. Približno od drugega do sedmega leta starosti traja temeljna gibalna stopnja, ko postaja gibanje usklajenejše in učinkovitejše. Otroci preskušajo in raziskujejo svoje gibalne sposobnosti in zmogljivosti ter tako spoznavajo sebe in okolje. Ob koncu obdobja temeljne gibalne stopnje obvladajo temeljne gibalne kompetence. Otrok zato potrebuje spodbudno okolje, priložnost za dejavnost in učenje.

Po sedmem letu starosti nastopi specializirana gibalna stopnja. Prehodno obdobje, ki traja približno do desetega leta, je prvo na tej stopnji gibalnega razvoja. $V$ tem obdobju začne otrok povezovati in uporabljati temeljne gibalne spretnosti tudi za izvajanje specializiranih športnih spretnosti. Izvajanje gibalnih spretnosti je vse bolj nadzirano, izpopolnjeno in hitro. Stabilnostne, lokomotorne in manipulativne spretnosti postanejo natančnejše, sestavljene in dovršene ter se smiselno uporabljajo $v$ vse kompleksnejših športnih in drugih gibalnih dejavnostih v vsakodnevnem življenju (Gallahue idr., 2011). Osnova za razvoj gibalnih spretnosti je razvoj živčnega sistema in s tem povezane kontrole gibanja, posledično je intenzivnejši razvoj nekaterih gibalnih sposobnosti, predvsem reakcijskega časa, koordinacije in hitrosti gibanja, ki se pojavljajo $v$ tem času. To obdobje je za otroke zelo pomembno in zanimivo. Otroci so aktivni v odkrivanju in kombiniranju različnih gibalnih vzorcev, navdušeni 
so zaradi vse večjih gibalnih zmogljivosti $\bigvee$ tem obdobju naj bi jim zagotovili predvsem pestro izbiro različnih gibalnih dejavnosti, kar bo izdatno izboljšalo nadzor gibanja in gibalno učinkovitost $v$ celoti. Preozka omejenost pri izbiri in premajhna pogostost gibalnih/športnih dejavnosti v povezavi z bogatimi gibalnimi izkušnjami in usvajanjem gibalnega znanja imata lahko nezaželene učinke v naslednjih obdobjih otrokovega gibalnega razvoja.

Pri otrocih se najprej razvijejo velike mišične skupine (Malina idr., 2004), ki omogočajo plazenje, hojo, mahanje, prijemanje itd. Predšolski otroci imajo relativno višje centralno težišče telesa, zato so tudi bolj nagnjeni k padanju (Pišot in Planinšec, 2010). Razvitejši zgornji del telesa (trup) prevladuje nad slabše razvitimi nogami in rokami. Do starosti šestih let se otrokovo telo razvija $v$ razmerjih telesa, ki so že podobnejša razmerjem telesa odraslega, kar mu nudi boljšo oporo in boljši občutek ravnotežja. Aktivacija velikih mišičnih skupin pa je nujno potrebna za pravilen telesni in gibalni razvoj. Razvitost gibalnih sposobnosti, tako prirojena kot pridobljena, odločilno prispeva k razvitosti gibalne kompetence. Razvoj gibalnih sposobnosti je posledica predvsem genetskega zorenja in vplivov okolja, pri čemer gre za proces, s pomočjo katerega otrok pridobiva gibalne kompetence in je nedvomno povezan $s$ kronološko starostjo, ni pa od nje povsem odvisen, ter poteka skozi razvojne stopnje, za katere so značilna posamična gibalna vedenja (Gallahue idr., 2011). Od gibalnih sposobnosti, ki so prirojene $v$ različnem deležu, najbolj hitrost - hitra mišična vlakna in najmanj moč, je odvisna izvedba gibov.

Ravni uravnavanja gibanja pri človeku so zavestna, avtomatska in refleksna. Prvi otrokovi gibalni vzorci so refleksni, ki se delijo na položajski, stojno-gibalni in postavitveni refleks. Sledijo naravne oblike gibanja, filogenetsko pogojene, ki se delijo na elementarna in sestavljena gibanja.

$V$ razvoju se otrok neprestano srečuje z gibalnim učenjem in usvajanjem novih, vse zahtevnejših gibalnih kompetenc, kar je v precejšnji meri pogojeno $z$ ravnjo gibalnih sposobnosti. Višja kot je raven razvitosti gibalnih sposobnosti, uspešnejši bo vzporeden proces gibalnega poučevanja, posledično pa bo na višji stopnji tudi usvojenost gibalnih kompetenc, kar se bo kazalo skozi kakovostno izvajanje različnih gibalnih spretnosti. Gibalne sposobnosti so temelj za izvajanje različnih gibalnih spretnosti, čeprav ne smemo pozabiti, da so pri tem pomembne tudi druge človekove sposobnosti in značilnosti. Prenizka raven gibalnih sposobnosti pogosto zmanjšuje možnosti uspešnega poučevanja na gibalnem področju, nasprotno pa visoka raven omogoča izvajanje vse zahtevnejših gibalnih spretnosti. Razvoj na gibalnem področju zagotavlja pridobivanje gibalnih kompetenc, ki jih otroci v otroštvu visoko vrednotijo in ki pomembno vplivajo tudi na druga razvojna področja (Pangrazi, 2000), za- 
to je njegovo spodbujanje z ustrezno kakovostjo in količino primernih gibalnih/športnih dejavnosti ena izmed temeljnih razvojnih nalog v otroštvu (Pišot in Planinšec, 2010). Značilnosti refleksne in začetne faze so opisane s pomočjo gibalnih vzorcev, saj v prvih dveh letih otrokovega življenja predstavljajo način njegovega gibanja. Temeljna gibalna faza predstavlja stopnjo, v kateri gibanje postaja vse usklajenejše. Otroci raziskujejo zmogljivosti svojega telesa in gibanja, ki jih pridobijo na tej stopnji (spoznajo uporabo naravnih oblik gibanja, razne igre, v zreli stopnji pa začnejo spoznavati kombinacije gibanj v raznih športih); tu pridobijo temeljne gibalne spretnosti. Po vstopu v osnovno šolo pa nastopi zadnja, specializirana gibalna faza, $v$ kateri otrok že začne z izvajanjem kompleksnejših športnih dejavnosti. Zadnja faza je najodvisnejša od okolja, v katerem otrok živi. Tem več spodbud in možnosti za razvijanje in spoznavanje športnih spretnosti ima, tem boljši bo njegov razvoj na športnem področju (Pišot in Planinšec, 2010). Vključevanje raznovrstnih naravnih oblik gibanja je v zgodnjem otroštvu za kakovostno in učinkovito gibalno poučevanje zelo pomembno, zato si v nadaljevanju oglejmo značilnosti teh oblik.

\section{OPREDELITEV GIBALNEGA RAZVOJA}

v nadaljevanju predstavljamo izbrane opredelitve gibalnega razvoja, ki se med seboj sicer razlikujejo, ampak imajo nekaj skupnih točk: proces, razvoj gibalnih sposobnosti, interakcija z okoljem in spremembe. Pišot in Planinšec (2010) menita, da gibalni razvoj kot proces spreminjanja funkcionalnih kompetenc skozi čas določa spremembe v gibalnem vedenju skozi celoten življenjski ciklus, izhajajoč iz interakcije med zahtevami gibalnih nalog, posebnostmi posameznika in pogoji okolja (Gallahue idr., 2011).

Gibalni razvoj je proces, ki v življenju posameznika skozi različna življenjska obdobja omogoča prehod na višjo raven gibalnih kompetenc - raven razvoja gibalnih sposobnosti in usvajanja zahtevnejših nadrejenih gibalnih znanj v nenehni interakciji in soodvisnosti z okoljem (Pišot in Planinšec, 2010).

Gibalni razvoj predstavljajo dinamične in večinoma kontinuirane spremembe v gibalnem vedenju, ki se kažejo v razvoju gibalnih (koordinacija, moč, hitrost, ravnotežje, gibljivost in natančnost) in funkcionalnih sposobnosti (vzdržljivost) ter gibalnih znanj, ki skupaj sestavljajo prostor gibalnih kompetenc in se manifestirajo kot: 
- stabilnostne,

- lokomotorne in

- manipulativne spretnosti (Pišot in Planinšec, 2010; Gallahue idr., 2011).

Pri tem stabilnostne kompetence razumemo kot posturalni nadzor telesa (drža, hoja), lokomotorne kot premikanje telesa (skoki, teki, plavanje) ter manipulativne kot rokovanje telesa s predmeti (lovljenja, meti, sunki).

Gibalni razvoj je proces, v katerem otrok usvaja gibalne spretnosti, kar je rezultat medsebojnega vplivanja genetskih in okoljskih dejavnikov (Latash, 2008). Genetski dejavniki so odločilni za živčno-mišično zorenje in morfološke značilnosti, predvsem v smislu velikosti, razmerij in sestave telesa, fizioloških značilnosti ter hitrosti rasti in zorenja (Malina idr., 2004; Haywood idr., 2012; Sheridan idr., 2008). Med okoljskimi dejavniki imajo najpomembnejši vpliv predhodne gibalne izkušnje in pridobivanje novih gibalnih izkušenj (Pišot in Planinšec, 2010). Zelo pomemben segment gibalnega razvoja je razvoj gibalnih sposobnosti, ki v daljšem obdobju poteka kontinuirano, čeprav so značilna občasna obdobja stagnacij in tudi upadanja (Pišot in Planinšec, 2010). Nekatere gibalne sposobnosti dosežejo najvišjo raven prej, druge pozneje.

Za zgodnje otroštvo je značilno, da je razvoj nekaterih gibalnih sposobnosti (npr. hitrosti in koordinacije) zelo intenziven, razvoj drugih (npr. ravnotežja, moči, gibljivosti in vzdržljivosti) pa nekoliko počasnejši (Malina idr., 2004). Prav tako je značilno, da se pojavljajo pomembne individualne razlike: vsak posameznik ima svoj tempo razvoja, ki ga določa njegova »biološka ura« (Gallahue idr., 2011). Razlike med spoloma so v obdobju zgodnjega otroštva v povprečju majhne, izrazitejše so $\mathrm{v}$ poznejših obdobjih. $\mathrm{V}$ določenih pogledih dosegajo nekoliko višjo raven gibalne učinkovitosti deklice (npr. koordinacija gibanja rok, ravnotežje), v drugih pa dečki (npr. koordinacija gibanja vsega telesa, agilnost, moč) (Planinšec, 2001; Rajtmajer, 1997). Dečki so nekoliko uspešnejši pri izvajanju gibalnih nalog, ki zahtevajo moč in hitrost, kot so skoki, meti in teki, medtem ko deklice uspešneje izvajajo spretnosti, ki zahtevajo natančnejše gibanje z rokami, ravnotežje in ritem, kot npr. plesi (Pišot, 1997).

Celoten gibalni razvoj otroka poteka od preprostih refleksnih gibov do hotenih in sestavljenih gibanj. Refleksni gibalni vzorci se $v$ naslednjih stopnjah razvoja kmalu izgubijo, nekateri pa se ohranijo celo življenje. Med njimi so tudi taki, ki imajo pri učenju kompleksnih gibalnih nalog velik pomen, npr. stojno-gibalni vzorci (vlečenje, potiskanje, sunek v telo, premik težišča telesa). Ti refleksni gibalni vzorci so osnova za nadaljnji razvoj temeljnih gibalnih vzorcev in kasneje gibalnih stereotipov (Pišot in Planinšec, 2010; Videmšek in Pišot, 2007; Gallahue idr., 2011). 
Različni deli otrokovega telesa rastejo z različno dinamiko. Velike mišične skupine se razvijejo med prvimi (Malina idr., 2004), tako se elementarni gibalni vzorci, ki vključujejo delo teh mišičnih skupin (plazenje, hoja, mahanje, prijemanje in drugi), pojavijo najprej. Predšolski otroci imajo relativno višje centralno težišče telesa, zato so tudi bolj nagnjeni k padanju (Pišot in Planinšec, 2010). Otrokov razvoj poteka večsmerno in hkrati na različnih področjih, kar pomeni, da je gibalni razvoj tesno povezan s telesnim, spoznavnim, čustvenim in socialnim razvojem. Za področje gibalnega razvoja veljajo temeljne zakonitosti, ki so značilne za človekov razvoj nasploh, kljub temu pa obstaja nekaj posebnosti. $V$ začetnem obdobju gibalni razvoj poteka v cefalokavdalni smeri, pri čemer je otrok najprej sposoben nadzirati gibanje glave, nato trupa in rok, šele potem nog, ter v proksimodistalni smeri, kar pomeni, da lahko otrok najprej nadzira gibanje tistih delov telesa, ki so bliže hrbtenici, kasneje pa tudi vse oddaljenejših. Tako otrok postopno postaja sposoben nadzirati in učinkovito izvajati vse zahtevnejše gibalne spretnosti (Pišot in Planinšec, 2010).

Gibalni razvoj je povezan s kronološko starostjo, ni pa od nje odvisen. Poteka skozi različna obdobja, ki jih imenujemo razvojne stopnje in v katerih lahko opazimo določeno vrsto značilnega gibalnega vedenja, ki velja za večino otrok. Vsaka razvojna stopnja je na nek način rezultat predhodne in pogoj za vzpostavitev naslednje, višje stopnje (Gallahue, 2011). Posamezne stopnje se večinoma pojavljajo v enakih starostnih obdobjih in trajajo približno enako dolgo. Zaporedje razvojnih stopenj je pričakovano, odvisno je namreč od dozorevanja funkcij, ki so gensko pogojene. Čeprav je vrstni red pojavljanja razvojnih stopenj praviloma enak, se zaradi individualnih razlik lahko pojavijo v različnih starostnih obdobjih, zato je treba pri obravnavanju stopenj gibalnega razvoja to upoštevati. Gibalni razvoj je dinamičen proces; za razliko od tradicionalne toge obravnave se sodobni pogledi nanj nanašajo na kontinuiteto, specifičnost in individualnost razvojnih procesov (Haywood idr., 2012).

Model peščene ure kot eden izmed modelov večdimenzionalnega, dinamičnega in odprtega sistema (Gallahue idr., 2011) opisuje pridobivanje gibalnih kompetenc skozi faze gibalnega razvoja ob upoštevanju osebnostnih dejavnikov (dednosti) in okoljskih dejavnikov ter realizaciji posameznih gibalnih nalog. Na določeni stopnji človekovega razvoja se peščena ura obrne. Posameznik začne z uporabo pridobljenih gibalnih kompetenc skozi filter genetike in posameznikovega življenjskega sloga, še vedno pa okno dograjevanja t. i. bazena gibalnih kompetenc ostaja odprto za nove gibalne izkušnje skozi proces gibalnega poučevanja. 
Vpliv dejavnikov sodobnega življenjskega sloga je $v$ današnjem času vedno agresivnejši. Medsebojna interakcija dejavnikov razvoja ob podaljševanju življenjske dobe ponuja priložnost za neprekinjeno spremljanje poglobljenih sprememb in procesov. Tako $v$ obravnavi razvoja človeka $v$ ospredje vedno bolj prihajajo njegove funkcionalne kompetence. Gibalna kompetenca kot osnova človeškega gibalnega kapitala, ki pomeni v celostnem delovanju človeka in v procesu ohranjanja ter zagotavljanja zdravja temeljni vzvod, je ena izmed tistih potrebnih človekovih zmožnosti, ki skozi vsa življenjska obdobja pomembno prispeva $\mathrm{h}$ kakovosti življenja in razvoja. Zaradi tega lahko obdobje, ki ga danes posvečamo spremljanju in preučevanju posameznikovega gibalnega razvoja z upoštevanjem vloge trajnosti in ekološke perspektive, imenujemo kompetenčno usmerjeno obdobje.

\section{PISANJE Z ROKO KOT KAZALNIK RAZVOJA GIBALNIH SPOSOBNOSTI}

Sodobni življenjski slog vedno bolj izključuje klasično pisanje z roko in s pisalom na papir; slednjega nadomeščajo drsenje po elektronskih napravah in pritiskanje tipk na tipkovnici ali pa opuščanje pisanja nasploh. Tovrstno ravnanje lahko označimo kot zamujeno priložnost za celostni razvoj otroka, zato priporočamo uvajanje pisanja tudi $v$ gibalne dejavnosti. Pisanje $z$ roko namreč vzbudi in poveže obe možganski polobli. Centri za pisanje se aktivirajo in omogočijo gibalne, čutilne in miselne procese, ki se uskladijo v oblikovanju črk v besede in povedi. Če ni pisanja, se centri ne aktivirajo in ne delujejo. Na področju gibanja se še posebej aktivirajo programi za dinamično upravljanje prstov pišoče roke ter programi za usklajevanje premikov oči in drobnih gibov roke, ki se, če ni pisanja kot vzroka aktivacije, ne razvijajo kakovostno in skladno.

\section{POMEN IN VLOGA ELEMENTARNIH GIBALNIH VZORCEV V GIBALNEM RAZVOJU OTROKA}

Elementarni gibalni vzorci se kot preprosti gibalni vzorci, torej plazenje, hoja, skok, tek itd., pojavijo v najzgodnejšem otroštvu in so temelj za razvoj kompleksnejših gibalnih stereotipov: plavanje, kolesarjenje, rolanje, smučanje itd. 
Vse gibe lahko razdelimo $v$ tri skupine $s$ predvidljivimi gibalnimi izidi - vzorci:

1. refleksni,

2. hoteni in

3. ritmični gibalni vzorci.

Refleksni so enostavni in od naše volje neodvisni gibi (dihanje, kihanje, umaknitev...), so hitri in odvisni od dražljaja, ki jih izzove. Hoteni gibi se pričnejo z zavestno odločitvijo in praviloma sledijo gibalnemu načrtu. Ritmični gibalni vzorci pa so kombinacija - za začetek potrebujejo zavestno odločitev, potem pa delujejo kot refleksni vzorec, npr., pod zavestnim nadzorom je samo pričetek gibanja, nadaljevanje pa je stereotipno (hoja, tek, kolesarjenje, plavanje...).

V razvoju otroka in procesu usvajanja pomembnih gibalnih kompetenc imata spoznavanje in usvajanje različnih načinov gibanja, ki sta zlasti filogenetsko pogojena, torej predvsem prirojena $v$ fazi evolucije, pridobljena in značilna za človeka kot vrsto, izreden pomen. Hoja, tek, skok, plezanje, plazenje, lazenje, met in drugi so nujna gibalna predznanja za skladen gibalni razvoj človeka in so v posameznikovi gibalni potrebi usmerjena predvsem v zadovoljevanje kvantitativne vrednosti gibanja in doseganje cilja, pri tem pa kakovost tega gibanja ni v ospredju (Videmšek in Pišot, 2007). Naravne oblike gibanja lahko razdelimo v tri temeljne skupine (Pistotnik, 2011):

I. pedipulacija oz. lokomocije (vsa premikanja telesa v prostoru), npr. plazenje, lazenje, hoja, tek, plezanje, skoki (v višino, daljino in globino), padci;

II. manipulacije (osnovne gibalne operacije s posameznimi deli telesa), npr. meti, lovljenja, udarci, blokade in prijemi;

III. osnovna sestavljena gibanja, ki jih največkrat uporabljamo v vsakdanjem življenju, npr. potiskanje, vlečenje, dviganje in nošenje.

Različni avtorji (Pistotnik, Pinter in Dolenec, 2002; Videmšek in Visinski, 2011) navajajo enajst pomembnih naravnih oblik gibanja pri gibalnem razvoju otroka (prirejeno po Pistotnik idr., 2002): (1) plazenja so gibanja, pri katerih se za premikanje v prostoru uporabljajo roke, noge in trup, pri čemer je trup v stiku s podlago; (2) lazenja so gibanja, pri katerih se vadeči premikajo s pomočjo rok in nog, trup pa je dvignjen od podlage; (3) hoja je osnovna oblika gibanja, ki jo uporabljamo za premikanje v prostoru; (4) tek je hitrejše gibanje, pri katerem se zaradi močnejših in hitrejših odrivov od podlage pojavi brezpodporna faza (faza leta); (5) padci so gibanja telesa iz praviloma višjega, pokončnega 
položaja v nižji položaj (najpogosteje leže); (6) plezanja so gibanja, pri katerih se vadeči premika v različnih vesah s pomočjo svojih okončin; (7) skoki so gibanja, za katera je značilno, da so sestavljeni iz treh faz, odriva, leta in doskoka; ločimo tri vrste skokov, v daljino, višino in globino; (8) potiskanja so gibanja, pri katerih je objekt običajno pred vadečim, ki ga skuša odriniti od sebe; (9) vlečenja so gibanja, pri katerih skuša vadeči objekt potegniti k sebi, kar pomeni, da se bo objekt gibal k izvoru sile oz. bo sila usmerjena od objekta; (10) dviganja so gibanja, pri katerih predmete ali lastno telo premikamo v nasprotni smeri od sile gravitacije; (11) nošenja so gibanja, pri katerih se predmet med premikanjem $v$ prostoru zadržuje $v$ dvignjenem položaju. 



\section{GIBALNE SPOSOBNOSTI}

Sposobnosti so tiste, ki določajo razlike med tem, kar kdo more, in tem, ali to tudi zmore. Pomenijo zgolj potencial, da posameznik lahko uresniči nek izid, in niso že same po sebi dosežek. Sposobnosti so tiste lastnosti, ki najbolj vplivajo na posameznikove dosežke in na njegovo uspešnost pri reševanju problemov (Musek in Pečjak, 2001).

Omenjena avtorja sposobnosti delita na duševne, gibalne in umske. Med umske spadata predvsem inteligentnost in ustvarjalnost. Sposobnosti zaznave okolja, kot npr. ostrina vida in kakovost sluha, sestavljajo duševne sposobnosti, medtem ko med gibalne sposobnosti uvrščamo moč, hitrost, gibljivost, koordinacijo, natančnost, ravnotežje in vzdržljivost. Gibalno sposobnost lahko $z$ drugimi besedami imenujemo tudi psihomotorična, psihofizična ali telesna sposobnost. Predstavlja dimenzije človeka, o katerih lahko sklepamo samo na podlagi konkretnega gibalnega dejanja (Pistotnik, 2011) in so pomemben segment motoričnega razvoja, ki sicer $v$ daljšem obdobju poteka kontinuirano, čeprav so značilna obdobja stagnacij in tudi upadanja sposobnosti (Pišot in Planinšec, 2005).

Gibalne sposobnosti so v osnovi odgovorne za izvedbo naših gibov. Omogočajo izvedbo gibalne naloge oz. gibanja človeka. V razvoju se otrok neprestano srečuje $z$ učenjem in izvajanjem novih, vse zahtevnejših gibalnih spretnosti, kar je zelo pogojeno z ravnjo gibalnih sposobnosti. Gibalne sposobnosti so zlasti zmožnosti, ki posamezniku omogočajo realizacijo gibalnih nalog, so merljive in na njihovi osnovi lahko ločimo razlike $v$ uspešnosti izvedbe določene gibalne naloge med dvema subjektoma pri enakih pogojih, znanju in mo- 
tivaciji (Videmšek in Pišot, 2007). Gibalne sposobnosti so, tako kot tudi druge človekove sposobnosti, $v$ določeni meri prirojene, $v$ določeni meri pa tudi pridobljene. Človeku so že z rojstvom dane osnovne zasnove, ki opredeljujejo stopnjo, do katere se bodo sposobnosti lahko razvile ob njegovi normalni rasti in razvoju (Pistotnik, 2011), seveda pa jih posameznik v procesu vadbe oz. treninga z lastno dejavnostjo lahko razvija in ohranja.

So naravne danosti človeka, odvisne predvsem od delovanja različnih organskih sistemov, in predstavljajo zmožnost izkoristka teh potencialov pri doseganju zastavljenih gibalnih ciljev. Pravimo, da gibalne sposobnosti temeljijo na anatomsko-fizioloških predispozicijah človeka. Epstein (2015) je preučeval izsledke številnih raziskovalcev gibalnega poučevanja in treniranja ter povzel, da sta talent in trening prepletena ter oba odločata o vrhunsko razvitih gibalnih sposobnostih in dosežkih/presežkih. Pravilo o sistemu usmerjene vadbe, ki temelji na meji zmožnosti vadečega (Ericsson, 2006), sicer posplošeno govori o »10.000 ur vadbe do mojstrstva«, vendar so nevroznanstveniki dokazali, da z ustreznim številom primernih ponavljanj izbranih opravil spreminjamo možgansko strukturo zlasti čelnega režnja, kar omogoči avtomatizacijo izvajanja gibalnih struktur (Duerden in Laverdure-Dupon, 2008). Tako so potrdili zgodnje domneve nekaterih znanstvenikov (Thorndike, 1908), da je talent $v$ bistvu samo nakopičena praksa, ki temelji na meji zmožnosti vadečega, in da vpliv vaje prevlada nad razlikami v prirojenih sposobnostih.

\section{DELITEV GIBALNIH SPOSOBNOSTI}

Za preglednejše razumevanje uporabljamo modele, ki nam poenostavljeno predstavijo zapletene procese. Na področju modeliranja gibanja se uporabljata strukturni in funkcionalni model klasifikacije gibalnih sposobnosti. Modela se ne izključujeta, temveč se dopolnjujeta, saj vsak s svojega vidika obravnavata isto področje (Pišot in Planinšec, 2005).

Različni avtorji (Pistotnik, 2011; Cemič, 1997; Retar, Pišot in Jelovčan, 2016) predstavljajo sedem glavnih gibalnih sposobnosti (šest gibalnih in eno funkcionalno). Posamezna sposobnost je ključnega pomena za otrokovo gibalno delovanje, saj vsebuje določene značilnosti. Gibalne sposobnosti delimo na koordinacijo, gibljivost, moč, hitrost, ravnotežje in natančnost ter funkcionalno sposobnost vzdržljivosti. V nadaljevanju bomo podrobneje predstavili v slovenskem prostoru uveljavljene opredelitve gibalnih sposobnosti kot ključnih tvorcev gibalne kompetence. 


\section{RAVNOTEŽJE}

Ravnotežje opredeljujemo kot sposobnost človeka, da ohrani stabilen položaj telesa. Sposobnost ravnotežja predstavlja sposobnost ohranjanja stabilnega položaja telesa znotraj podporne površine telesa in hitrega oblikovanja kompenzacijskih gibov, s katerimi ga vzpostavljamo oz. ohranjamo, kljub sili gravitacije in drugim motečim dejavnikom. Vložena sila, ki je za to potrebna, mora biti sorazmerna sili, ki izzove odklone telesa v stabilnem položaju, drugače se ravnotežni položaj poruši v nasprotno stran. Ravnotežje je sposobnost natančne določitve smeri in intenzivnosti kompenzacijskih gibov, s katerimi se ohranja ali vzpostavlja ravnotežni položaj telesa v prostoru.

Ravnotežje je sposobnost hitrega oblikovanja kompenzacijskih gibov, ki so potrebni za vračanje telesa v ravnotežni položaj, kadar je ta porušen (Pistotnik, 2011). Ravnotežje pomeni ohranjanje stabilnega položaja ter ga delimo na dinamično in statično (Cemič, 1997). Na ravnotežje vplivajo tudi telesni dejavniki. Poleg centra ravnotežnostnega organa v srednjem ušesu (vestibularni aparat) in ravnotežnostnega centra $v$ malih možganih jim pomagajo tudi čutili vida in sluha, taktilni receptorji, Golgijev tetivni aparat in mišično vreteno (Pistotnik, 2011). Ravnotežje je pri predšolskem otroku zelo težko obvladljiva gibalna sposobnost. Sicer se začne razvijati že ob rojstvu, ampak se nekje do šestega leta še ne razvije popolnoma. S starostjo ravnotežna sposobnost ponovno upada (Cemič, 1997).

Ohranjanje človekovega težišča je pomembno za kakovostno življenje, še posebej pa je pomembno za gibalno učinkovitost. Težišče človeka, ki je v stoji (vertikalni položaj telesa, kjer je teža enakomerno porazdeljena na obe no- 
gi), zaradi vplivov sile gravitacije na telo stalno niha, kar se kaže v minimalnih odklonih od vertikale. Zaradi tega se morajo nenehno in hitro oblikovati ustrezni korektivni programi, s katerimi se ohranja ravnotežni položaj. Pri tem se kompenzacijski gibi izvajajo v nasprotni smeri od odklonov težišča in so izvršeni z ustrezno silo, da se položaj težišča telesa ohrani v mejah podporne površine. Za oblikovanje ustreznih korektivnih programov sta potrebni sinteza informacij iz okolja in lastnega telesa ter sprotna obdelava sprejetih informacij. Glede na odklon težišča sledi ustrezen odgovor prek mišic, kar posledično vzpostavlja ravnotežje.

\section{DEJAVNIKI, KI POGOJUJEJO RAVNOTEŽJE}

Ključne dejavnike delimo na tri področja:

I. ravnotežni organ v srednjem ušesu;

II. ravnotežni center v malih možganih;

III. pomožni organi: čutili vida in sluha, tetivni in mišični receptorji, receptorji v obsklepnih strukturah in taktilni receptorji v koži.

Čutilo vida omogoča zaznavanje grobih odmikov telesa od stabilnega položaja. Zato morajo $v$ prostoru obstajati določene orientacijske točke (fiksne, stalne točke), na katere se lahko oprejo človekove zaznave o položaju telesa. Če teh točk v prostoru ni ali če se jih ne vidi (zaprte oči), ni prave predstave o položaju lastnega telesa v prostoru in je oteženo ohranjanje ravnotežnega položaja. Čutilo sluha tako kot čutilo vida omogoča določene zaznave iz okolja, na osnovi katerih se lažje ohranja ravnotežni položaj (odboj zvoka od predmetov), vendar pa je to čutilo manj pomembno kot vizualne zaznave.

Taktilni receptorji registrirajo spremembe pritiskov, ki se zaradi odklonov projekcije težišča pojavijo na tistih delih kože, ki so v stiku s podporno ploskvijo. Posredujejo predvsem podatke o sili pritiska na podlago in smeri odklonov težišča. Kinestetična čutila predstavljajo tetivni in mišični receptorji (mišično vreteno, Golgijev tetivni aparat) ter receptorji v okolici sklepov. Odgovorna so za regulacijo mišičnega tonusa in s tem za regulacijo sile, ki je v korektivnih programih potrebna za popravljanje odklonov težišča od optimalnega položaja. Receptorji registrirajo spremembe napetosti v mišicah ter kotne premike in pospeške v sklepih. Odgovorni so za drobno regulacijo gibanja. Ravno- 
težni organ je v srednjem ušesu in je sestavljen iz treh polkrožnih kanalov, ki so postavljeni v vseh treh tipičnih ravninah (frontalni, sagitalni in horizontalni). $\mathrm{V}$ kanalih so čutne dlačice, ki so oblite $s$ tekočino. Čutne dlačice so receptorji, ki ob premikih glave reagirajo na premik tekočine. Center za ravnotežje je v malih možganih, ki informacije sprejema. Na osnovi aferentne sinteze se aktivirajo refleksni regulacijski mehanizmi, ki dajejo sorazmerne odgovore glede na odklone telesa $v$ mejah podporne ploskve. Na tej osnovi se oblikujejo ustrezni korektivni programi glede na smer in jakost odklona.

Pojavni obliki ravnotežja sta:

I. sposobnost ohranjanja ravnotežnega položaja;

II. sposobnost vzpostavljanja ravnotežnega položaja.

Sposobnost ohranjanja ravnotežnega položaja je sposobnost hitrega oblikovanja kompenzacijskih gibov, ki so sorazmerni z odkloni telesa od stabilne postavitve $v$ ravnotežnem položaju. Ta sposobnost je pomembna, kadar je posameznik v nekem stabilnem položaju in nanj delujejo različne zunanje sile, ki ta položaj rušijo (nasprotnik, sila sunka giba itd.), ali pa takrat, kadar se izključijo posamezni receptorji, ki so pomembni za ohranjanje ravnotežnega položaja (predvsem čutilo vida).

Sposobnost vzpostavljanja ravnotežnega položaja je sposobnost čim hitrejše postavitve $v$ ravnotežni položaj po predhodnih motnjah receptorjev vestibularnega aparata. Po gibanju, ki poruši ravnotežni položaj, je treba ta položaj čim hitreje ponovno stabilizirati. Osnovne informacije za izdelavo korektivnega programa naj bi se $v$ tem primeru pridobivale iz pomožnih receptorjev (vid, sluh, tip, napetost mišic ipd.). Ta sposobnost je pomembna, kadar posameznik izvaja hitre spremembe smeri ali pa zaustavitve po rotacijskih gibanjih (športna gimnastika, umetnostno drsanje, ples ipd.).

\section{MERSKI POSTOPKI ZA UGOTAVLJANJE RAVNOTEŽJA}

Gibalni testi za ugotavljanje ravnotežja se glede na dve pojavni obliki pojavljajo $v$ dveh različicah, in sicer kot testi ohranjanja ravnotežnega položaja in testi vzpostavljanja ravnotežnega položaja. Priporočamo uporabo stične hoje, ko otrok hodi tako, da postavlja nogo pred nogo na tak način, da se s peto prve noge dotakne prstov druge noge. Šteje se dolžina prehojene poti brez padca oz. odmika noge za vzpostavitev ravnotežja. 


\section{METODE RAZVOJA RAVNOTEŽJA}

Za metodo razvoja ravnotežja sta značilna izbor situacijske vadbe in glede na kakovost izvedbe vaj(e) prilagojeno število njenih ponovitev. Razvoj sposobnosti ohranjanja ravnotežnega položaja naj temelji na:

- rušenju ravnotežja (zunanje sile delujejo na telo),

- izključevanju čutil (predvsem vida in sluha) in

- zmanjševanju podporne ploskve.

Razvoj sposobnosti vzpostavljanja ravnotežnega položaja pa temelji na predhodnem motenju vestibularnega aparata z rotacijskimi gibanji v različnih ravninah. Sposobnost manifestacije ravnotežja je pod velikim vplivom količine gibalnih/športnih dejavnosti in vadbe. Po prenehanju vadbe se dokaj hitro vrne na nižji nivo. 


\section{KOORDINACIJA}

Koordinacija ali usklajenost gibanja je gibalna sposobnost, odgovorna za učinkovito oblikovanje in izvajanje sestavljenih gibalnih nalog z osnovnimi značilnostmi gibanja, kot so (preglednica 4) pravilnost, pravočasnost, racionalnost, izvirnost in stabilnost (Videmšek in Pišot, 2007; Pistotnik, 2011). Kaže se $v$ učinkoviti realizaciji časovnih, prostorskih in dinamičnih dejavnikov gibanja.

Koordinacijo opredeljujemo kot sposobnost, ki nam omogoča učinkovito oblikovanje in izvajanje sestavljenih, zapletenih gibalnih nalog. Je najznačilnejša gibalna sposobnost za človeško vrsto (Pistotnik, 2011). Pomeni usklajevanje gibov v prostoru in času (prostorska orientacija). Pomembno se je zavedati telesa, smeri in telesa v prostoru. Koordinacija se nekje do šestega leta starosti močno razvija (takrat pridobimo največ izkušenj). Do enajstega leta je njen razvoj še vedno strm, nato pa do petnajstega leta malce upade. Po petnajstem letu začne ponovno malo naraščati do dvajsetega leta, nato pa postopoma upada (Pistotnik, 2011). Koordinacija je kot gibalna sposobnost povezana še z močjo, ravnotežjem in s hitrostjo (Cemič, 1997). Najpomembnejše obdobje za njen razvoj je predšolska doba, zato kompetentnost strokovnih delavcev predstavlja ključ njenega uspešnega razvoja. Koordinacijo bi lahko opredelili tudi kot sposobnost usmerjenega izkoristka:

- energijskih,

- toničnih in

- programsko gibalnih potencialov za izvedbo kompleksnih gibanj. 
V dobro koordiniranem gibanju se uporabi le toliko energije, kolikor je te za izvedbo gibanja nujno potrebne, da bo to potekalo lahkotno, mehko in sproščeno. Koordinirano gibanje zahteva tudi dobre programske potenciale, ki se oblikujejo le na osnovi že usvojenih gibanj, torej na osnovi gibalnega poučevanja in transfera gibalnih informacij. Človek s številnejšimi gibalnimi izkušnjami ima na voljo večjo količino podatkov o različnih gibanjih in s tem večje možnosti za njihovo združevanje v nove, kakovostnejše gibalne odgovore glede na položaje, v katerih se znajde.

\section{OSNOVNE ZNAČILNOSTI KOORDINIRANEGA GIBANJA}

Kot podporo pri presoji, v kolikšni meri je izbrano gibanje koordinirano, lahko uporabljamo kriterije iz spodnje preglednice.

\section{Preglednica 4: Osnovne značilnosti koordiniranega gibanja \\ (prirejeno po Pistotnik, 2011)}

Pravilnost (natančnost, ustreznost izvedbe gibov)

Pravočasnost (časovna usklajenost gibov)

Racionalnost (učinkovitost in ekonomičnost izvedbe gibov)

Izvirnost (samoiniciativnost v prilagajanju gibanja različnim zahtevam)

Stabilnost (zanesljivost, identičnost izvedbe v ponavljanjih)

Razvoj koordinacije se začne v fetalnem obdobju, saj plod v materinem telesu že pridobiva prve gibalne izkušnje. V največji meri pa lahko otroci te izkušnje pridobivajo do približno šestega leta starosti. To je obdobje, v katerem so najdojemljivejši za sprejem raznovrstnih gibalnih informacij in njihovo združevanje v gibalne strukture na višjem nivoju. Živčni sistem je namreč še izjemno plastičen (mielinizacija živčnih vlaken še ni zaključena) in se lahko z različnimi gibalnimi dejavnostmi nanj še značilno vpliva. Do začetka pubertete (okrog enajstega leta starosti) je ta razvoj še vedno dokaj strm, čeprav v nekoliko manjšem vzponu kot do šestega leta. V obdobju pubertete sposobnost koordinacije nekoliko upade, kar je predvsem posledica hitre rasti skeleta. Mišice namreč ne sledijo hitri rasti kosti, zato se poveča njihov tonus. Daljši vzvodi, ki jih take kosti predstavljajo, pa so tudi moteč dejavnik pri izvedbi gibov. Ko se telesna rast umiri, človek postopoma spet pridobiva na koordinaciji, svoj vrhunec v manifestaciji koordinacije pa doseže okrog dvajsetega leta staros- 
ti. Ta nivo lahko zadrži nekako do petintridesetega leta, medtem ko je nadaljnja manifestacija odvisna predvsem od njegovega načina življenja in fizioloških procesov v živčnem sistemu.

\section{DEJAVNIKI, OD KATERIH JE ODVISNA KOORDINACIJA}

Koordinacija je bolj kot katerakoli druga gibalna sposobnost odvisna od učinkovitega delovanja centralnega živčnega sistema. V centralnem živčnem sistemu se namreč oblikujejo gibalni programi, s katerimi so opredeljeni:

- ravnine in amplitude gibov,

- hitrost in jakost njihove izvedbe ter

- položaji telesa, in sicer v odvisnosti od zunanjih dejavnikov.

Poznamo tri temeljne dejavnike razvoja koordinacije:

I. sistem za sprejem in analizo informacij,

II. center za gibalni spomin ter

III. kortikalni in subkortikalni centri za oblikovanje gibanja.

Sistem za sprejem in analizo informacij: predstavlja vsa čutila, živčne poti od njih do centralnega živčnega sistema in center za analizo informacij v njem. Ta sistem je prvi nivo, ki presoja o kakovosti informacij iz okolja in lastnega telesa, tako da se lahko neko gibanje na osnovi njegove presoje programira čim skladneje in se zato tudi čim popolneje izvede.

Centri za oblikovanje gibanja: informacije iz navedenih receptorjev potujejo po sprejemnih živčnih poteh $v$ centralni živčni sistem, kjer se združeno analizirajo $v$ centru za analizo informacij (aferentna sinteza in analiza informacij). Rezultat takšne aferentne sinteze je pridobitev predstave o potrebnem gibanju ali o položaju delov lastnega telesa. Tako obdelane informacije nato potujejo v gibalne centre, kjer se ustvarjajo gibalni programi - gibalni odgovori na sprejete informacije. Kortikalni in subkortikalni centri za oblikovanje gibanja so odgovorni za oblikovanje ustreznih gibalnih programov.

Realizacija gibanja: ukazi iz kortikalnih in subkortikalnih centrov za oblikovanje gibanja potujejo po eferentnih živčnih poteh (poti za odgovore) do mišic, ki realizirajo gibanje in sprožijo ustrezen odgovor na konkretne okoliščine, $v$ katerih se telo nahaja. 
Center za gibalni spomin: $v$ fazi analize informacij omogoča primerjavo podatkov in vnaprejšnjo odstranitev tistih, ki niso pomembni za oblikovanje novega gibalnega programa. $V$ fazi oblikovanja novega gibalnega programa pa je pomemben tudi t. i. gibalni transfer (prenos), ki omogoča hitrejše dojemanje novih gibanj na osnovi izkoriščanja informacij iz že usvojenih gibalnih programov. Med gibalnimi programi, ki so shranjeni v centru za gibalni spomin, se namreč nenehno iščejo podobnosti z novimi gibanji, ki se jih uči vadeči. Čim več takih podobnosti se najde, hitreje in lažje se je naučiti novega, do tedaj neznanega gibanja. V fazi izvajanja gibanja pa center za gibalni spomin s svojo bazo gibalnih izkušenj omogoča hitro formiranje korektivnih programov gibanja v subkortikalnih centrih.

\section{MERSKI POSTOPKI ZA UGOTAVLJANJE RAZVITOSTI KOORDINACIJE}

Gibalni testi za ugotavljanje razvitosti koordinacije so sestavljeni tako, da posnemajo gibalne situacije, ki od merjencev zahtevajo, da v čim večji meri aktivirajo tiste gibalne in funkcionalne sisteme, ki so za posamezno pojavno obliko koordinacije najznačilnejši.

Če npr. želimo ugotoviti, koliko so razvite sposobnosti za realizacijo celostnih programov gibanja, lahko uporabimo naslednji gibalni test: koraki vstran bočno, izmenično v levo in desno med dvema črtama, ki sta zarisani na tleh. Razdaljo mora testiranec preiti šestkrat v pravilni izvedbi. Merimo čas, v katerem pravilno opravi nalogo. Predpisano gibanje predstavljajo: prisunski koraki, bočno gibanje in določena razdalja med črtama (4 m). Vsako odstopanje od predpisanega gibanja je napaka, zaradi katere se testirancu prehod med črtama ne prizna in mora izvesti ponovitev. To pomeni, da mora razdaljo preiti več kot šestkrat, s tem pa je tudi čas, ki ga za to porabi, daljši.

\section{SREDSTVA IN METODE ZA RAZVOJ KOORDINACIJE}

Pri vadbi se običajno uporablja metoda večkratnega ponavljanja gibalnih struktur, ki se morajo izvajati na različne načine, v odvisnosti od značilnosti posamezne pojavne oblike. Treba je tudi vedeti, da natančna merila in metode za gibalne/športne dejavnosti koordinacije, pri katerih bi lahko točno določi- 
li obremenitev vadečih, niso znana. Poznana so le temeljna načela in sredstva za razvoj posameznih pojavnih oblik koordinacije.

Razvoj sposobnosti za realizacijo celostnih programov gibanja lahko izvajamo z:

- elementi tehnike športov in naravne oblike gibanja v fazi poučevanja;

- vadbo po postajah ali frontalno;

- metodo večkratnega ponavljanja iste gibalne naloge oz. problema, pri čemer se morajo upoštevati metodični postopki in učna načela (počasneje - hitreje, ob varovanju - prosto, s pomočjo - samostojno itd.), ter

- nestrukturiranimi gibalnimi igrami.

Ne morejo pa se upoštevati načela postopnega obremenjevanja, ker je vadeči postavljen pred nalogo in jo mora kot tako izvesti v celoti. Pomembni so povratne informacije vadečemu in učenje velikega števila različnih gibalnih oblik.

Gibalne naloge naj postajajo vedno zapletenejše, kar se doseže z/s:

- opravljanjem gibanja z nedominantno roko, nogo;

- povečanjem hitrosti izvedbe gibanja;

- omejitvami prostora za izvedbo gibanja;

- spreminjanjem vadbenih pogojev, še preden se gibalni program stabilizira;

- gibanjem v vseh smereh (nazaj, levo, desno, bočno ...);

- vključevanjem preusmeritev (med izvajanjem gibalne naloge otrok našteva različna osebna imena, barve, živali in podobno).

Vadeči se morajo namreč čim večkrat znajti v novem, nepoznanem položaju in ga skušati čim hitreje pravilno, pravočasno ter učinkovito in izvirno razrešiti.

\section{POMEN KOORDINACIJE}

Koordinacija je $v$ veliki meri povezana $z$ manifestacijo vseh ostalih gibalnih sposobnosti, zato morajo biti te ustrezno razvite, tako da se koordinacija lahko tudi z njihovo pomočjo izrazi na višjem nivoju. Tako je koordinacija povezana z: 
- manifestacijo velikih amplitud gibov (gibljivost), ki so odvisne od medmišične in znotrajmišične koordinacije;

- manifestacijo mišične sile (moč), ki je odvisna od ustrezne in pravilne inervacije mišic;

- manifestacijo hitrosti, ki je odvisna od usklajenosti izvedbe zaporednih gibov;

- manifestacijo natančnosti, ki je odvisna od inervacije in natančnega doziranja sile gibov;

- manifestacijo ravnotežja, ki je odvisno od natančne izvedbe korekcijskih gibov. 


\section{GIBLJIVOST}

Gibljivost je sposobnost za izvedbo gibov z maksimalno amplitudo. Delimo jo na statično, ko zadržujemo gib, in dinamično, s katero dosegamo maksimalno amplitudo. Gibljivost je torej gibalna sposobnost doseganja maksimalnih razponov (amplitud) gibov v sklepih ali sklepnih sistemih posameznika.

Gre za gibalno sposobnost, s katero dosegamo maksimalne obsege (amplitud) gibov v sklepih posameznika (Pistotnik, 2011). Cemič (1997) navaja topološko delitev gibljivosti s petimi členi, in sicer gibljivost: ramenskega obroča, hrbtenice (trupa), kolčnega sklepa, zapestja in skočnega sklepa. Prav tako kot ravnotežje tudi gibljivost delimo na statično in dinamično. Za razliko od drugih gibalnih sposobnosti ta z leti upada, iz česar izhaja, da so najgibljivejši otroci. Termin prožnost (lahko tudi elastičnost) naj bi bil podrejen terminu gibljivost, ker opredeljuje le sposobnost mišice, da se pod vplivom sile raztegne in se po prenehanju delovanja le-te nanjo ponovno vrne v prvoten položaj. Termin gibčnost pa naj bi bil nadrejen terminu gibljivost, saj označuje lastnost človeka, da neko gibanje opravlja hitro, koordinirano in z velikimi amplitudami, kar pomeni, da je gibčnost posameznika odvisna tudi od njegove gibljivosti. Primerna stopnja gibljivosti je pomemben dejavnik splošnega dobrega počutja, saj je mišična sproščenost, ki je pogojena tudi z ustrezno stopnjo gibljivosti, $v$ tesni povezavi $z$ zmanjšanjem psihične napetosti. $Z$ zmanjševanjem telesne dejavnosti se slabša splošna sposobnost za delo. $Z$ nedejavnostjo se namreč zmanjšuje tudi gibljivost $v$ sklepih, zaradi česar lahko velikost amplitude giba pade celo pod raven, ki je nujna za izvajanje vsakdanjih opravil. Zmanjšana gibljivost vpliva na siromašenje gibalne izraznosti človeka (na 
kakovost in estetiko giba), torej na prvine, ki predstavljajo pomemben dejavnik v polnosti življenja vsakega posameznika. Pri mlajših starostnih skupinah je skoraj 80 \% bolečin v križu predvsem posledica zmanjšanja gibljivosti v nekaterih sklepih gibalnega aparata in neustreznega mišičnega steznika, ki naj bi podpiral hrbtenico. In nenazadnje je gibljivost tudi pomembna kakovost pri vseh športnih dejavnostih (še posebno pri estetskih športih - športna gimnastika, umetnostno drsanje ipd.) in pomemben dejavnik pri izrazu ostalih gibalnih sposobnosti (koordinacije, moči, hitrosti, natančnosti ipd.).

\section{PRIROJENOST GIBLJIVOSTI}

Kakšno gibljivost bo človek sposoben izraziti, je odvisno od stopnje prirojenosti in od nekaterih dejavnikov, ki jih je treba poznati, če se želi vplivati na njeno povečanje. Stopnja prirojenosti je za gibljivost sorazmerno nizka, saj njen koeficient prirojenosti znaša $50 \%$, kar pomeni, da se lahko na njen razvoj vpliva v relativno velikem obsegu. Izražanje gibljivosti je zato v največji meri odvisno od sistematičnega vpliva na različne dejavnike, ki jo pogojujejo.

\section{DEJAVNIKI GIBLJVOSTI}

Dejavnike gibljivosti delimo na zunanje in notranje. Notranji dejavniki so vezani na zgradbo in delovanje človekovega telesa ter so: anatomski, morfološki, fiziološki, biološki in psihološki. Zunanji dejavniki pa so vsi ostali, ki na človekovo telo vplivajo iz okolja: temperatura okolja, dnevno obdobje in prehrana ipd. Podrobneje predstavljamo morfološke in fiziološke dejavnike.

\section{NOTRANJI DEJAVNIKI}

\section{MORFOLOŠKI DEJAVNIKI}

Transverzalna dimenzionalnost (premeri sklepov) - široki sklepi z veliko površino naj bi imeli zaradi svoje oblike negativen vpliv na gibljivost. Prav tako pa se lahko na osnovi širokih sklepov sklepa o obstoju širokih mišičnih pripojev nanje in s tem o večji moči mišic, kar vsekakor negativno vpliva na gibljivost.

Podkožna tolšča (debelina maščobnega sloja pod kožo) - debelejše plasti maščobnega tkiva pod kožo ovirajo izvedbo gibov z veliko amplitudo, zato so suhi ljudje običajno gibljivejši. Kadar pa mišično maso na skeletu zaradi opus- 
titve vadbe nadomesti maščobno tkivo, lahko to za krajši čas prispeva celo $\mathrm{k}$ boljši gibljivosti, saj se maščobno tkivo v manjši meri upira raztezanju kot pa mišično. Na navedene dejavnike se lahko z ustrezno vadbo vpliva v večji meri, tako se lahko obsklepne strukture $z$ raztezanjem zrahljajo in podaljšajo, na obliko sklepov pa se lahko vpliva le delno in še to samo v zgodnji mladosti, ko je kostno in sklepno tkivo mehkejše in bolj plastično.

Longitudinalna dimenzionalnost (dolžinske mere skeleta) - dolžina telesnih segmentov daje navidezno prednost pri izvedbi velikih amplitud gibov, vendar je to običajno le večji doseg segmenta, medtem ko je gibljivost manjša, saj je ovirana s kratkimi in bolj napetimi (toniziranimi) mišicami.

Voluminoznost telesa (obsegi telesnih segmentov) - daje oceno mišične mase na telesu. Ljudje z veliko mišično maso so običajno manj gibljivi, ker masa sama po sebi fizično ovira izvedbo velikih amplitud gibov $v$ sklepih, $v$ določeni meri pa tudi pogojuje večji mišični tonus, ki zmanjšuje izvedbo velikih amplitud.

\section{Vpliv na morfološke dejavnike}

Od morfoloških dejavnikov se lahko v največji meri vpliva na voluminoznost telesa in podkožno mastno tkivo. Na transverzalno dimenzionalnost se lahko v manjši meri vpliva z gibalno/s športno dejavnostjo le pri mlajših starostnih kategorijah, pa še takrat se širina sklepa le povečuje, kar negativno vpliva na gibljivost. Na dolžinske mere skeleta se $v$ smislu športne priprave ne more vplivati. Zato se, če je ta značilnost telesa pomembna za določen šport, uporablja selekcija vadečih in na tej osnovi se izbirajo ustrezno grajeni posamezniki.

\section{FIZIOLOŠKI DEJAVNIKI}

Ključna sta mišična temperatura in mišični tonus - stanje mišične napetosti, ki je v možganih centralno regulirano in deluje na nivoju refleksa. Center za regulacijo mišičnega tonusa pa ne deluje pri vseh ljudeh enako, zato imajo nekateri posamezniki višji tonus in drugi nižjega. Višji mišični tonus negativno vpliva na gibljivost.

\section{Vpliv na fiziološke dejavnike}

Visok nivo vzdraženosti centra, ki je odgovoren za mišični tonus, se lahko zmanjša s sprostilnimi vajami in z zavestnim psihičnim sproščanjem. Lokalna mišična temperatura pa se lahko poviša z mišično dejavnostjo (mišične kont- 
rakcije - krčenje) ali dovajanjem toplote iz okolja, zato je za maksimalen izraz gibljivosti nujno potrebno predhodno ogrevanje.

\section{ZUNANJI DEJAVNIKI}

\section{Temperatura okolja}

Nizke zunanje temperature negativno vplivajo na gibljivost. Običajno se pred mrazom da zaščititi z obleko (več tankih slojev, med katerimi je zrak kot izolator) in tako okrog telesa ustvariti lastno mikroklimo, ki se jo lažje nadzoruje in vpliva nanjo.

\section{Lokalna mišična temperatura}

Temperatura posamezne mišice je odvisna od človekove dejavnosti. Zaradi lastne dejavnosti je mišica bolje prekrvavljena, z razpadom energijskih materij v njej pa se ob mehanski energiji sprošča tudi toplotna energija, kar vse skupaj poviša temperaturo mišice. Z ogrevanjem se tako v mišicah zmanjša viskoznost (židkost), to je gostota tekočin, s čimer se poveča njihova sposobnost raztezanja.

\section{Obdobje dneva}

Najmanjša gibljivost se lahko izrazi v jutranjih urah, to je med četrto in peto uro. Nato se stopnja gibljivosti viša nekako do dvanajste ure, ko doseže najvišjo točko. V obdobju kosila gibljivost spet nekoliko upade, nakar ponovno raste do sedemnajste ali osemnajste ure. Po tem obdobju, predvsem pa v času spanja, se ponovno zniža na minimalno vrednost.

\section{Prehrana}

Kot dejavnik gibljivosti je prehrana pomembna le toliko, kolikor vpliva na strukturo mase telesa, pri čemer se običajno misli na povečevanje količine podkožnega mastnega tkiva. Za ustrezno stopnjo gibljivosti je pomembno tudi vnašanje ustreznih količin tekočine, da lahko mišice ohranjajo potreben nivo viskoznosti in s tem ustrezno elastičnost. 


\section{STRUKTURA GIBLJIVOSTI}

Topološki kriteriji:

- gibljivost rok v ramenskem obroču;

- gibljivost trupa;

- gibljivost nog v kolčnem sklepu.

Kot aktivna gibljivost je poimenovana tista oblika gibljivosti, pri kateri se maksimalna amplituda giba doseže $z$ lastno mišično silo. Ta oblika gibljivosti je $v$ veliki meri odvisna od moči agonistov in prožnosti vezivno-mišičnega tkiva antagonistov.

Pri pasivni gibljivosti pa se maksimalne amplitude gibov dosegajo pod vplivom zunanjih sil, ki jih generirajo partner, masa telesa, lastna roka, ki razteza nogo, ipd. Ta oblika gibljivosti je odvisna predvsem od prožnosti vezivno-mišičnega tkiva. Pri vadbi pasivne gibljivosti se običajno dosegajo večje amplitude gibov kot pri aktivni obliki. Pasivna gibljivost pa predstavlja osnovo za razvoj aktivne gibljivosti, ki je pri športni dejavnosti pomembnejša, saj je v športu treba gibe najpogosteje izvajati aktivno.

\section{MERSKI POSTOPKI ZA UGOTAVLJANJE GIBLJIVOSTI}

Uporabljamo zlasti laboratorijske meritve, situacijske gibalne teste in orientacijske normative. Orientacijski normativi se uporabljajo le za hitro oceno stanja gibljivosti glede na grobe kriterije, ki so bili izbrani ali so bili določeni. Pri takšnem ocenjevanju gibljivosti je možna uporaba večstopenjske lestvice ocen (npr. dobro, zadovoljivo, slabo), glede na katero se merjenci razvrščajo po merjeni sposobnosti v približno enakovredne skupine.

\section{Primer testa gibljivosti: predklon stoje, kolena iztegnjena}

Z dlanmi se dotakne tal.

* dobra gibljivost (posebna vadba za gibljivost ni potrebna)

$S$ prsti se dotakne tal.

* zadovoljiva gibljivost (potrebna je zmerna vadba gibljivosti)

Ne dotakne se tal.

* slaba gibljivost (potrebna je resna gibalna/športna dejavnost za razvoj gibljivosti) 


\section{METODE RAZVOJA GIBLJIVOSTI}

V praksi se uporabljajo dinamična aktivna metoda razvoja gibljivosti, pri kateri uporabljamo gimnastične vaje (balistične), pri katerih se maksimalna amplituda giba doseže z zamahom, telesni segment pa se takoj vrača v izhodiščni položaj, statična metoda razvoja gibljivosti, pri kateri uporabljamo gimnastične vaje, pri katerih se maksimalno amplitudo giba doseže postopoma ter se jo zadrži določeno časovno obdobje, in vaje aktivnega ali pasivnega raztezanja. Pri otrocih te metode ne uporabljamo.

\section{DINAMIČNA METODA RAZVOJA GIBLJIVOSTI}

Uporabljajo se zamašni, to so balistični gibi, s katerimi se skuša telesni segment spraviti do maksimalnega razpona (amplitude) giba. Po tem se segment takoj vrača v izhodiščni položaj. Tak način vadbe je zato lahko boleč, saj se mišice, vezi in sklepne ovojnice zelo hitro raztegnejo do skrajne meje. Pri hitrem, nekontroliranem raztezanju obstaja tudi možnost natrganja mišičnih vlaken, ki ima lahko za vadečega hude posledice (prekinjen program gibalnih/ športnih dejavnosti, nezmožnost tekmovanja itd.). Zaradi tega se dinamična metoda razvoja gibljivosti v zadnjem času vedno bolj opušča. Dinamično raztezanje pa se, ravno zaradi svoje dinamike in s tem večjega vpliva na funkcionalne sisteme, še vedno zelo pogosto uporablja pri splošnem ogrevanju.

\section{STATIČNA METODA RAZVOJA GIBLJIVOSTI}

Pri predšolskih otrocih odsvetujemo uporabo statične (pasivne) metode razvoja gibljivosti, zato jo samo predstavljamo. Metoda namreč zahteva zadrževanje posameznih telesnih segmentov v položaju maksimalne amplitude giba, ki je lahko otrokovemu zdravju škodljivo. Vztrajanje v položaju maksimalnega mišičnega raztezanja naj bi trajalo 10-30 sekund, posamična vaja (posamično vztrajanje v raztegu) se mora pri tej metodi večkrat ponoviti. Med ponovitvami so odmori za sprostitev, ki so običajno vsaj dvakrat daljši kot vztrajanje v položaju raztezanja. 


\section{POMEN DOBRE GIBLJIVOSTI}

Pri predšolskih otrocih je gibljivost relativno dobro razvita in je ni treba posebej izrazito razvijati, ampak predvsem vzdrževati. Ključne prednosti dobro razvite gibljivosti so: uspešno usvajanje tehnike gibanja; večja ekonomičnost gibanja; manjša možnost poškodb; estetski videz pri nekaterih športih; odpravljanje pomanjkljivosti slabe telesne drže; olajšano opravljanje gibanj v vsakdanjem življenju; pozitiven vpliv na izraznost ostalih gibalnih in funkcionalnih sposobnosti (moč, hitrost, koordinacija, vzdržljivost itd.).

\section{Okvare hrbtenice in gibljivost}

Posledica dolgotrajnega sedenja je med drugim tudi pojav skrajšanja mišic upogibalk kolka. Upogibalke potegnejo zgornji rob medenice naprej, kar povzroči povečanje hrbtenične lordoze (pretirana ukrivitev v ledvenem predelu hrbtenice). Prilagoditev na tako stanje oz. dolgotrajno zadrževanje telesa $v$ takem neustreznem pokončnem položaju povzroči spremembe $v$ razporeditvi pritiskov na sklepne površine vretenc. To pa lahko izzove obrabo ali celo pokanje medvretenčnih diskov in pogosto tudi obrabo fibroznih struktur v kolčnem sklepu. Raztezne vaje, s katerimi se ohranjajo optimalni telesni položaji, je zato priporočljivo izvajati vsakodnevno, še posebej pa po večjih mišičnih naporih in po dolgotrajnem sedenju.

\section{Ogrevanje telesa kot povečevanje gibljivosti}

Ogrevanje se vedno začne s primerno aerobno dejavnostjo (tekalne dejavnosti, pospešena hoja itd.), s čimer dosežemo dvig telesne temperature in tako telo pripravimo na napor. Ogrevanje telesa se nato nadaljuje $z$ ustrezno izbranimi razteznimi vajami za povečevanje gibljivosti, pri čemer so posebej priporočljive dinamične raztezne vaje. $Z$ izvedbo vaj gibljivosti se skozi mišico pospeši pretok sveže in tople krvi, ki je polna energijskih tvarin, ob razpadu katerih se sprošča še dodatna toplota, ki mišico ogreje. Raztezanje mišic naj bi bilo sestavni del vsakega ogrevanja pred napornejšo telesno dejavnostjo. 



\section{MOČ}

Moč, nekateri strokovnjaki jo imenujejo tudi sila, razumemo in opredeljujemo kot sposobnost opravljanja dela v enoti časa. Sila mišic je sila, ki nastaja na osnovi krčenja skeletne mišice - pretvorbe kemične energije v mehansko.

Moč je zmožnost telesa za učinkovito izkoriščanje sile mišic pri premagovanju zunanjih sil in se pojavlja v treh oblikah: eksplozivni (hitrostno premagovanje zunanjih sil), repetitivni (ponavljajoče se premagovanje zunanjih sil) in statični (dolgotrajno napenjanje mišic) (Pistotnik, 2011). Sposobnost moči lahko delimo po različnih kriterijih: topološkem kriteriju (moč rok, nog, trupa itd.), manifestacijskem kriteriju (statična, dinamična itd.), kriteriju z vidika silovitosti mišičnega krčenja (največja moč, hitra moč, vzdržljivost v moči) oz. kriteriju funkcionalnega pristopa, ki izhaja iz osnovnih mehanizmov manifestacije gibalne naloge (Škof, 2017; Ušaj, 2003; Pistotnik, 2011). V mišici se kemična energija pretvarja v mehansko in toplotno energijo, pri čemer se izzove mišično krčenje (napenjanje, krčenje), zunanji izraz katerega je mišična sila. Moč človeka pa je produkt sile in hitrosti. Najpogostejša zunanja sila, ki deluje na telo človeka, je sila gravitacije oz. težnosti $(\mathrm{Fg})$, ki telo vleče $\mathrm{k}$ tlom - to sta masa telesa in masa predmetov, s katerimi posameznik rokuje (nekatere mišice se morajo stalno upirati delovanju te sile, da ohranjajo pokončno držo telesa - to so antigravitacijske mišične skupine). Koeficient prirojenosti moči je nizek in znaša okoli o,50. To pomeni, da je moč še v nadaljnjih $50 \%$ mogoče razviti z lastno dejavnostjo. $V$ kakšnem odstotku se lahko moč resnično razvije z načrtnim delom, je odvisno od posameznih pojavnih oblik moči, ki imajo različne, specifične koeficiente prirojenosti. Zato je treba dobro poznati dejavnike, od katerih 
je moč odvisna in na katere se lahko - v smislu povečanja moči - sistematično vpliva v zgodnjem otroštvu.

\section{MORFOLOŠKI DEJAVNIKI MOČI}

Voluminoznost telesa naj bi v glavnem predstavljala predvsem količino mišične mase v telesnih segmentih človeka. Večja količina mišične mase pa je sposobna ustvariti večjo količino mehanske energije, kar se kaže v večji proizvodni sili, pri čemer pa ne gre zgolj za količino mišične mase, ampak vedno tudi za njeno kakovost.

\section{Vpliv na morfološke dejavnike moči}

$V$ večji voluminoznosti se izraža vadba za povečanje mišične mase. Z ustrezno prehrano in vadbo se lahko zmanjšuje količina podkožnega maščevja. Na longitudinalno dimenzionalnost skeleta se - v smislu gibalnih/športnih dejavnosti za povečanje moči - ne more vplivati. Pod vplivom večjih obremenitev pa se lahko pri mlajših dosežejo določene spremembe v transverzalni dimenzionalnosti telesa. Sila, ki prek tetive deluje na kostno prijemališče, namreč spodbudi razmnoževanje kostnih celic in njihovo boljšo prekrvavljenost, kar povzroči dograjevanje kostnega tkiva. To pa se lahko doseže samo pri mlajših starostnih kategorijah, ki so še v fazi razvoja in rasti skeleta.

\section{FUNKCIONALNI DEJAVNIKI MOČI}

To so tisti dejavniki, ki so povezani z upravljavskim sistemom za delovanje mišic. Predstavljajo jih sistemi, ki programirajo in nadzirajo gibanje ter vključujejo ustrezne mišice v delo. Delimo jih na:

- dejavnost gibalnih centrov v centralnem živčnem sistemu (gibalni korteks), ki s proženjem akcijskih potencialov, to je električnih impulzov, vzdražijo mišice, ki so odgovorne za akcijo (več impulzov pomeni tudi večjo moč);

- prevodnost živčnih poti, po katerih potujejo impulzi do mišic (boljša kot je prevodnost, večja moč se lahko izrazi); 
- propustnost sinaps - stiki med živci (večja prepustnost omogoča večjo moč);

- kakovost biokemičnih procesov, ki potekajo v mišicah in omogočajo presnovo energije.

Posledica dobrega delovanja naštetih funkcij je aktivacija večjega števila gibalnih enot $v$ mišici (to je znotrajmišična (intramuskularna) koordinacija - vključitev ustreznih gibalnih enot mišice) in medmišična (intermuskularna) koordinacija - usklajenost delovanja posameznih mišic in mišičnih skupin pri izvajanju gibanja.

Z gibalnimi/s športnimi dejavnostmi se lahko vpliva na razvoj in krepitev moči, na hitrost proženja in količino akcijskih potencialov $v$ gibalnih centrih, na prevodnost živčnih poti in prehodnost sinaptičnih barier ter s tem na povečanje števila aktiviranih gibalnih enot. $Z$ redno vadbo gibalne strukture športa (njegove tehnike) pa se izboljša tudi medmišična koordinacija in s tem izkoristek generirane sile.

\section{PSIHOLOŠKI DEJAVNIKI MOČI}

Ti dejavniki so emocionalna afektna stanja (stanja močnega čustvovanja), vedenjske značilnosti, motivacija in patološka psihična stanja (psihična obolenja). Emocionalna afektna stanja lahko vplivajo na pojavnost moči. V stanjih, kot sta strah in jeza, je človek sposoben izraziti neprimerno večjo moč kot v normalnem, umirjenem stanju. $V$ afektnih stanjih pa lahko zaradi vpliva hormonov pride do inhibicije (zaviranja delovanja) inhibitornega centra. $\mathrm{S}$ tem se kontrolno-zaviralna funkcija tega centra zmanjša in gibalnim centrom se omogoči, da prožijo večje število impulzov. Zaradi tega je človek sposoben aktivirati celo 50-60 \% gibalnih enot in $s$ tem manifestirati večjo moč, kot je to običajno. Druga emocionalna stanja (npr. trema) pa lahko izraz moči zavrejo, ker povzročijo intra- in intermišično (znotrajmišično in medmišično) nekoordiniranost, ki izzove zakrčenost in neusklajeno delovanje mišic. Motivacija prav tako vpliva na pojavnost moči, saj so motivi temeljno gibalo človeka, ki ga žene k doseganju in uresničevanju izbranih ciljev. Ustrezna motivacija lahko značilno vpliva na povečanje izraza moči, zato je treba poskušati otroke dobro motivirati, da lahko premagajo na videz nepremostljive gibalne probleme. 


\section{BIOLOŠKI DEJAVNIKI MOČI}

Med te dejavnike uvrščamo spol, starost in prehranjenost, ki tudi vplivajo na moč. Med spoloma obstajajo razlike v moči. Moški so v povprečju statistično značilno močnejši od žensk. Te razlike so takšne, da se najmočnejše ženske v primerjavi normalnih krivulj razporeditve moči po spolu prepletajo z najšibkejšimi moškimi. Ženska ima namreč po svoji zgradbi zelo gracilen (nežen) skeletni sistem, za 1/3 manj mišične mase in več podkožnega mastnega tkiva. Njeni telesni segmenti so $v$ povprečju krajši in je manj agresivna, v telesu pa se ji izločajo nekateri specifični ženski hormoni (npr. estrogen), kar vpliva tudi na čvrstost tkiv. Ženske lahko izrazijo v povprečju le okrog 70 \% moči povprečnega moškega.

Starost je pomemben dejavnik moči. Povprečen, netreniran človek lahko svoj maksimum moči izrazi nekje med dvajsetim in tridesetim letom starosti, potem pa začne moč upadati, ker mišice počasi atrofirajo in spreminjajo svojo zgradbo. Proces imenujemo sarkopenija. Prav zato je pomembno, da otrokom razvijemo dovolj mišične mase - zaloge, da bo njena izguba $v$ starosti obvladljiva za samostojno in kakovostno življenje; to je naložba za starost v otroštvu. Z redno vadbo ali pa z uporabo moči pri vsakodnevnih opravilih so ti procesi upočasnjeni in moč se lahko na ustreznem nivoju ohrani še v pozno starost. Pozorni moramo biti na izbor vrste mišičnega naprezanja glede na starost. Tako pri predšolskih otrocih ni priporočljiva izvedba vaj statičnega naprezanja (npr. izvajanje vese v zgibi) ali pa statične raztezne vaje.

Strukturalne in funkcionalne spremembe kot posledice redne vadbe za moč se med drugim kažejo tudi v:

- delovanju gibalnih centrov na višjem nivoju in zato v proženju večjega števila akcijskih potencialov;

- izboljšanju prevodnosti živčnih poti in prehodnosti sinaptičnih barier;

- hkratnem aktiviranju večjega števila gibalnih enot;

- povečanju in izboljšanju energijskih depojev ter v izboljšani kapilarizaciji mišic;

- izboljšanju znotraj- in medmišične koordinacije;

- postavljanju mišičnih vlaken $v$ ustreznejši kot za izvedbo mišičnega krčenja. 


\section{METODE RAZVOJA MOČI}

Temeljna načela, ki se morajo upoštevati pri razvoju moči, so:

- mišica se krepi samo takrat, ko se aktivno napenja (izvedene morajo biti mišične kontrakcije);

- dražljaji na živčno-mišično tkivo morajo biti intenzivnejši, trajnejši in pogostejši, kot so običajno v vsakdanjem življenju;

- obremenitev je zaradi prilagoditve telesa treba postopno povečevati;

- za vsako resnejšo vadbo moči se je treba predhodno dobro ogreti;

- nujni sestavni del vsake vadbe za razvoj moči so poleg krepilnih tudi raztezne in sprostilne gimnastične vaje, da se ohranijo funkcionalne značilnosti mišice;

- za vsako pojavno obliko moči je potrebna posebna metoda vadbe;

- upoštevati je treba učinkovito razmerje med aktivnostjo in počitkom - regeneracijo;

- upoštevati je potrebno biološke/fiziološke zakonitosti, da samo tako intenzivna vadba, ki povzroča mikroraztrganine - poškodbe mišičnih vlaken, lahko spodbuja proces obnovitve, okrepitve ter povečanje mišice.

Najpogostejša sredstva za razvoj moči otrok so krepilne gimnastične vaje brez bremen in elementarne igre z naravnimi oblikami gibanja. Najprimernejši rekviziti za razvoj moči pri otrocih so igralne in vadbene oblike z lastno telesno težo, izbrane naravne oblike gibanja (vlačenje, potiskanje itd.) in posamezniku ustrezno prilagojena manjša bremena (vrečke s peskom, stekleničke z vodo, lažje ročke, žoge, lutke, težje plišaste igrače itd.).

\section{MERSKI POSTOPKI ZA UGOTAVLJANJE MOČI}

Skok v daljino z mesta je standardni postopek oz. merska naloga za ocenjevanje eksplozivne moči in je kazalnik energijske regulacije gibanja, posredno pa pokaže tudi eksplozivno moč zlasti nog in trupa ter nakazuje gibalno sposobnost koordinacije merjenca. Rekviziti naj bodo otrokom prijazni in varni: posebna preproga z označenim merilom z dodanimi barvnimi pasovi in živalmi, kar je v ospredju, medtem ko seveda za potrebe ugotavljanja stanja in kasnejšega otrokovega napredka, ko merjenje ponovimo v enakih pogojih, merimo $v$ centimetrih. Merjenec stopi na preprogo za označeno črto in se sonožno odrine v daljavo. Odriv in doskok morata biti sonožna, sicer rezultat ne velja. 
Dolžina skoka se odčita glede na odtis pete, ki je bližje odrivnemu mestu - črti. Natančnost merjenja je $1 \mathrm{~cm}$. Merimo zadnji odtis telesa. Merjenec ima 2 poskusa, šteje boljši rezultat. Rezultat se zapiše $v$ centimetrih. Statistično značilnih razlik med slovenskimi dečki in deklicami pri starosti šest let ne beležimo. Njihova povprečna dolžina skoka $v$ daljino z mesta $v$ zadnjem desetletju znaša 112,2 cm (Starc, Strel, Kovač, Leskošek in Jurak, 2015) in nam je lahko v pomoč kot referenčna vrednost. Merjenje otrokom ne sme predstavljati stresa in ne sme temeljiti na razvrščanju: najboljši, najhitrejši ali zadnji, najslabši ... 


\section{HITROST}

Hitrost opredeljujemo kot sposobnost izvedbe gibanja v najkrajšem možnem času (Videmšek in Pišot, 2007). Pojavlja se lahko kot hitrost reakcije, hitrost posamičnega giba ali hitrost izmeničnih gibov in je od vseh sposobnosti najodvisnejša od dednosti.

Hitrost predstavlja sposobnost, s katero izvedemo gib z največjo frekvenco ali premagovanje ovir v najkrajšem času. Od vseh gibalnih sposobnosti je najodvisnejša od dednih lastnosti (Pistotnik, 2011). Cemič (1997) in Pistotnik (2011) njene pojavne oblike opredeljujeta različno. Pistotnik navaja hitrost reakcije, hitrost enostavnega giba in hitrost ponavljajočih se gibov, Cemič pa dodaja še hitrost izvedbe enega samega giba, sprint in agilnost. Gibalna hitrost se pri deklicah razvije nekje do dvanajstega leta, pri dečkih pa še malo kasneje (Cemič, 1997). Razvijanje hitrosti otrokom najhitreje približamo z dejavnostmi, ki vključujejo naravne oblike gibanja, predvsem elementarne igre in gimnastične vaje. Pomembna je predvsem pri premagovanju kratkih razdalj s cikličnim gibanjem (tek, plavanje, kolesarjenje ipd.) in pri gibalnih nalogah, ki zahtevajo hitro izvedbo posameznega giba. Od vseh gibalnih sposobnosti je hitrost $v$ največji meri odvisna od dednih lastnosti - koeficient prirojenosti znaša tudi več kot 0,90 .

DEJAVNIKI, KI VPLIVAJO NA RAZVOJ HITROSTI

Najpomembnejši dejavniki so: 
- fiziološki, ki so povezani z dejavnostjo živčnega sistema;

- biološki, ki so povezani s sestavo mišičnega tkiva;

- psihološki, ki na različne načine vplivajo na hitrost;

- morfološki, predvsem pri hitrem premikanju telesa v prostoru;

- razvitost ostalih gibalnih sposobnosti.

\section{FIZIOLOŠKI DEJAVNIKI}

- Dejavnost gibalnih centrov - če delujejo na višjem nivoju, so sposobni prožiti večje količine impulzov, kar vpliva na večji izraz hitrosti

- Prevodnost živčnih poti in prehodnost sinaptičnih barier - boljša prevodnost aferentnih in eferentnih živčnih poti (hitra informacija in hiter odgovor) zagotavlja večjo hitrost, saj je reakcija na dražljaj hitrejša.

- Mišični tonus - ustrezna tonizacija aktivnih in neaktivnih mišic pomeni večjo hitrost izvedbe gibanja, ki se pojavi zaradi hitrejših kontrakcij, manjšega zaviralnega momenta in manjše energijske potrošnje. Na vse te dejavnike se lahko pozitivno vpliva z ustreznimi programi gibalnih/športnih dejavnosti in se tako poveča hitrost izvedbe gibanja.

\section{BIOLOŠKA DEJAVNIKA}

- Struktura mišičnih vlaken - pri osebah, ki so po naravi hitre, lahko količina hitrih vlaken doseže tudi do $90 \%$ vseh vlaken v mišici; v povprečju je pri normalni populaciji razmerje med hitrimi in počasnimi vlakni približno 50 :50.

- Energijske zaloge $v$ mišici - glavno gorivo za mišično delo $v$ anaerobnih alaktatnih procesih sta pri manifestaciji velikih hitrosti kreatin fosfat (cp) in adenozintrifosfat (atp), količina teh snovi v mišici pa je omejitveni dejavnik trajanja manifestacije hitrosti. Maksimalno hitrost se lahko manifestira do 15 sekund, potem v mišici zmanjka energije in dejavnost mora preiti na aerobni nivo (zmanjšati se mora intenzivnost delovanja mišice zmanjša se hitrost izvedbe gibanja). $Z$ vadbo se $v$ večji meri ne more vpli- 
vati na strukturo mišičnih vlaken, lahko pa se do določene mere vpliva na povečanje energijskih depojev $v$ mišici in $s$ tem na možnosti, da se hitrost manifestira dalj časa (utrujenost se pojavi kasneje).

\section{PSIHOLOŠKA DEJAVNIKA}

- Motivacija, ki mora biti na primernem nivoju, saj le tako pripomore k ustrezni vzburjenosti gibalnih centrov in s tem $\mathrm{k}$ hitrejši izvedbi gibov. Tako premajhna kot prevelika motivacija imata lahko za izraz hitrosti negativne posledice (premajhno naprezanje za dosego uspeha ali pa gibalni blok zaradi prevelike želje po uspehu).

- Trema oz. strah, ki lahko $v$ določeni meri pozitivno vpliva na izraz hitrosti (predštartna trema, ki vzburi gibalne centre). $V$ preveliki meri pa trema na izraz hitrosti deluje negativno, saj povzroči večjo tonizacijo mišic (zakrčenost, togost, nekoordiniranost).

\section{MORFOLOŠKI DEJAVNIKI}

- Ustrezna voluminoznost telesa (razvitost mišične mase), ki je pozitiven dejavnik hitrosti. Prav tako transverzalna dimenzionalnost skeleta, ker široki sklepi nudijo čvrsto oporo močnim mišicam pri generiranju eksplozivne sile, ki je potrebna pri hitrih gibih.

- Podkožno mastno tkivo, ki je negativen dejavnik izraza hitrosti, saj ovira doseganje optimalnih amplitud gibov in predstavlja dodatno balastno maso, ki jo je treba premikati pri hitri izvedbi gibov.

- Longitudinalna dimenzionalnost skeleta, ki naj bi v načelu predstavljala negativen dejavnik izraza hitrosti, saj se s krajšimi segmenti dosega večja frekvenca gibov pa tudi inervacijske poti za vzdraženje efektorjev so na daljših segmentih daljše. Bolj izražena longitudinalna dimenzionalnost pa po drugi strani omogoča doseganje večjih amplitud gibov.

Na sposobnost hitrosti vliva tudi stopnja razvitosti ostalih gibalnih sposobnosti (gibljivost, moč, koordinacija itd.). Prilagojeni programi gibalnih/ športnih dejavnosti za razvoj teh treh gibalnih sposobnosti morajo biti sestav- 
ni del programov gibalnih/športnih dejavnosti za razvijanje hitrosti. Brez njihovega razvoja tudi tiste hitrosti, ki je dana z genskimi zasnovami, ni mogoče izkoristiti v celoti. S primerno gibalno/športno dejavnostjo se skuša vplivati predvsem na ustrezno povečanje mišične mase in na zmanjšanje podkožnega mastnega tkiva.

Struktura hitrosti sestoji iz hitrosti reakcije in hitrosti enostavnega giba. Hitrost reakcije je sposobnost hitrega gibalnega odziva na določen signal. Signal je lahko akustičen (pisk, strel ipd.) ali pa vizualen (premik nasprotnika, sprejem žoge ipd.). Pri tem so lahko reakcije na signal enostavne ali pa kompleksne. Tako je odziv na pričakovane dražljaje znan, na nepričakovane dražljaje pa je lahko različen. Hitrost enostavnega giba je sposobnost premika telesnega segmenta na določeni poti v najkrajšem možnem času, to je hiter premik telesnega segmenta iz mirovanja do določene točke v prostoru. Je najelementarnejša vrsta hitrosti in se kaže kot hitrost zamaha, sunka, udarca ali odriva.

\section{MERSKI POSTOPKI ZA UGOTAVLJANJE HITROSTI}

Gibalni test za frekvenco gibov se ugotavlja s testi tipa tapingov, v katerih je treba z izbranim telesnim segmentom izvajati čim hitrejše izmenične dotike različnih točk v prostoru. Točke morajo biti v taki medsebojni oddaljenosti, da se lahko dosežejo z izbranim telesnim segmentom, ne da bi se bilo pri tem treba premakniti z mesta. Običajno je rezultat testov število izmeničnih dotikov v določeni časovni enoti. Več dotikov pomeni boljši rezultat.

Hitrost v prostoru se ugotavlja s testi kratkih tekov. Glede zgodnjega otroštva nas zanima zlasti hitrost kakovostne izvedbe gibalnih vzorcev: da gibalno nalogo otroci izvedejo kakovostno in čim hitreje.

\section{METODE RAZVOJA HITROSTI}

- $\quad$ naravne oblike gibanja (hitri teki, teki v oteženih ali olajšanih pogojih - po strmini, v zavetrju ipd., hitro izvajanje ostalih gibanj);

- elementarne igre (starti z različnih položajev, igre hitre odzivnosti in igre hitrosti - npr. štafetne igre);

- gimnastične vaje za razvoj gibljivosti in moči;

- vaje za izboljšanje tehnike gibanja. 


\section{NATANČNOST}

Natančnost opisujemo kot sposobnost določitve ustrezne smeri in sile za usmeritev telesa ali predmeta $v$ želeni cilj. Pomembna je pri gibalnih akcijah, kjer se zadeva cilj (tarča), ali pa tam, kjer je treba izvesti gibanje po natančno določeni tirnici.

Natančnost predstavlja gibalno sposobnost, pri kateri je zelo pomembna natančna določitev smeri in intenzivnosti gibanja do želenega cilja. Pri natančnosti so zelo pomembni čutila vida, kinestetična čutila (mišično napenjanje) in osrednji živčni sistem (povezava s centri v možganskem deblu) (Pistotnik, 2011). Cemič (1997) natančnost deli na dve pojavni obliki: prva oblika je, da se vodeni predmet privede do cilja, druga oblika pa, da vrženi predmet zadene cilj. Natančnost je sposobnost za natančno določitev smeri in sile pri usmeritvi telesa proti želenemu cilju v prostoru tako $z$ vodenjem kot $z$ metom. Dejavniki natančnosti so slabo poznani, zato tudi ni znan natančen koeficient njene prirojenosti. Znano je le, da osnovne informacije za oblikovanje glavnih in korektivnih gibalnih programov natančnosti v osrednjem živčnem sistemu posredujejo čutilo vida (informacije o cilju, razdalji, gibanju ipd.) in kinestetična čutila (občutenje mišične napetosti). Struktura natančnosti je sestavljena iz sposobnosti zadevanja cilja z vodenim projektilom in sposobnosti zadevanja cilja z vrženim projektilom. 


\section{SPOSOBNOSTI ZADEVANJA Z VODENIM PROJEKTILOM}

Pri realizaciji ima vadeči možnost s korektivnimi gibalnimi programi ves čas vplivati na smer in hitrost gibanja projektila, ki se približuje cilju. Za to so značilni procesi reaferentacije, ki omogočajo sprotne popravke gibalnega programa. Na osnovi nenehnega dotoka informacij iz okolja se namreč gibanje projektila korigira in se ga usmerja čim bliže želenemu cilju (pojavlja se sukcesivna - zaporedna obdelava informacij). Ta pojavna oblika natančnosti je npr. pomembna pri hokeju (vodenje ploščka v gol), košarki (vodenje žoge pri košarki), alpskem smučanju (slalom med vratci).

\section{SPOSOBNOSTI ZADEVANJA Z VRŽENIM PROJEKTILOM}

Za realizacijo je značilno, da se na osnovi enkratne sinteze informacij izdela program lansiranja. Posamezna aferentna sinteza vizualnih in kinestetičnih informacij mora nuditi vse elemente za določitev trajektorije (krivulje, poti) in sile, ki sta potrebni za gibanje projektila do cilja (pojavlja se simultana - hkratna analiza informacij). Če so informacije korektne in njihova analiza uspešna (izkušnje), bo projektil cilj zadel, v nasprotnem primeru pa ne. Ta pojavna oblika natančnosti je pomembna pri rokometu, tenisu, odbojki, lokostrelstvu, nogometu (strel na gol) ipd.

\section{MERSKI POSTOPKI ZA UGOTAVLJANJE NATANČNOSTI}

Stopnja razvitosti natančnosti se meri z gibalnimi testi, za katere je značilno, da imajo slabo zanesljivost. Pri merjenju natančnosti, ki je pomembna za posamezne športe, se zato običajno uporabljajo posebni situacijski testi z več ponovitvami testne naloge. Bistvo testnih nalog je v zadevanju različnih ciljev na predpisan način. Običajno je rezultat testov število zadetkov ali pa število točk, ki jih merjenec doseže z zadetki v različne predele tarče. 


\section{METODE RAZVOJA NATANČNOSTI}

Pri vadbi zadevanja je pomembno, da se uporabljajo enake gibalne strukture, kot se pojavljajo pri gibanju oz. športu, za katerega se vadba izvaja (košarka - met iznad glave, met prek glave, met iz skoka ipd.). Treba je namreč usvojiti celoten program gibanja in ga avtomatizirati. Pri vadbi se lahko uporabljata metoda večkratnega ponavljanja in načelo postopnega obremenjevanja, če je to le mogoče. Manifestacije natančnosti so pod močnim negativnim vplivom utrujenosti in emocionalnih stanj, pri njihovem pojavljanju se natančnost poruši in zadevanje cilja oz. natančnost izvedbe gibanja je slabša. Zato vadbo, ko se pojavijo znaki utrujenosti, ki se odražajo v ponavljanju napak, prekinemo in jo nadaljujemo šele po odmoru za regeneracijo. 



\section{VZDRŽLJIVOST}

Strokovnjaki vzdržljivost opredeljujejo kot funkcionalno sposobnost, ki je odgovorna za zmožnost dlje časa trajajočega izvajanja gibalnih/športnih na$\log z$ enako učinkovitostjo. Vzdržljivost, ki jo nekateri prištevajo tudi med gibalne sposobnosti, naj bi spadala med funkcionalne sposobnosti, saj je odvisna predvsem od dobrega delovanja dihalnega in krvožilnega sistema.

Srčno-žilni in dihalni sistem pri otrocih še nista povsem razvita, kar pomeni, da pri že krajših naporih pride do hitrejše in večje obremenitve kot pri odraslih. Prav tako so pljuča v pomembni fazi razvoja, zato lahko preobremenitev dihalnega sistema zaradi prezahtevne vadbe ali igre negativno vpliva na kakovosten razvoj otroka. Pri otrocih še ni dokončana osifikacija kostnega sistema, zato se izogibamo prepogosti (vsakodnevni) in dolgotrajni vadbi vzdržljivosti (prekomerno zadihan, rdeč $v$ obraz, z nadpovprečnim srčnim utripom, prekomerno poten otrok), saj lahko izčrpava za rast kosti potrebne minerale in hranila.

$Z$ drugo besedo vzdržljivost poimenujemo kondicija. Delimo jo na splošno in specifično (ki se pojavlja ob določeni dejavnosti) ter na statično in dinamično (Cemič, 1997). Pri vzdržljivosti gre tako za mišično kot srčno-dihalno vzdržljivost. Odvisna je predvsem od aerobne sposobnosti posameznika in stopnje razvitosti njegovih drugih gibalnih sposobnosti. Nekateri avtorji jo delijo na osnovno in specialno vzdržljivost, pri čemer osnovno vzdržljivost pojmujejo kot učinkovito obvladovanje napora pri izvedbi gibalnih nalog, specialno pa kot uspešno premagovanje dolgotrajnega napora $v$ določeni športni panogi. 


\section{DEJAVNIKI, KI POGOJUJEJO VZDRŽLJIVOST}

Najpomembnejša sta ključna notranja dejavnika, in sicer:

- sposobnost za regulacijo energije, ki omogoča optimalen izkoristek energijskih potencialov pri izvedbi gibanja in je nadrejena predvsem moči ter hitrosti, in

- sposobnost za regulacijo gibanja, ki je odgovorna za oblikovanje, uresničevanje in nadziranje izvedbe gibalnih nalog v prostoru ter času in je $v$ hierarhičnem smislu nadrejena koordinaciji, gibljivosti, natančnosti in ravnotežju.

Vzdržljivost delimo lahko še glede na trajanje, in sicer na hitrostno - kratkotrajno, srednjo in dolgotrajno. Precej je povezana s posameznikovim celostnim zdravstvenim statusom, njegovo vitalnostjo in kakovostjo življenja. Z razvijanjem vzdržljivosti pri otrocih lahko bolj kot s katerimikoli drugimi gibalnimi dejavnostmi razvijamo za uspešno življenje pomembne človekove lastnosti, kot so vztrajnost, nepopustljivost, marljivost, doseganje oddaljenejših ciljev in samonadzor.

\section{METODE RAZVOJA VZDRŽLJIVOSTI}

Pri najmlajših vzdržljivost razvijamo zlasti z gibalnimi didaktičnimi igrami ter elementarnimi in $s$ štafetnimi igrami $z$ daljšo intenzivnostjo in $s$ krajšimi odmori. Primerna oblika je tudi fartlek kot način srednje dolgega izmenjavanja lahkotnega teka in hoje, ki mu lahko dodamo različne gibalno preproste igre ali naloge, da otrokom popestrimo tek (hoja iz obroča v obroč, plezanje preko ovire, prenašanje žog ...).

Fartlek pomeni predvsem igro hitrosti. Vključuje hitre in počasne teke, različne gibalne dejavnosti med aktivnostjo ter omogoča precej svobode in prilagajanja posamezniku med vadbo. Z metodo igre razvijamo vzdržljivost v predšolskem obdobju, in sicer tako, da uporabimo različno oddaljena mesta, od koder otroci nekaj prinašajo ali odnašajo ali rešujejo gibalni problem. Za učinkovit razvoj vzdržljivosti torej uporabljamo fartlek in gibalne igre. Cilj obeh je, da otrok čim večkrat prehodi in preteče primerne razdalje skladno $\mathrm{s}$ svojimi zmožnostmi. Vzdržljivost je funkcionalna sposobnost, ki se kaže v sposobnosti daljšega izvajanja gibanja z nezmanjšano učinkovitostjo. Primerna metoda, ki bi bila primerna za razvijanje vzdržljivosti v predšolskem obdob- 
ju, mora temeljiti na dejstvu, da si stopnjo napora oz. obremenitve vsak otrok prilagodi sam, kar pomeni, da se lahko ustavi kadarkoli, s čimer se preprečijo preobremenitve. 

III.

GIBALNO UČENJE IN POUČEVANJE 



\section{SPLOŠNO O GIBALNEM UČENJU IN POUČEVANJU}

Gibalno učenje obsega pojmovanje psihomotoričnega poučevanja (gibalnega) kot procesa oblikovanje sheme, $s$ katero so urejeni odnosi med informacijami, ki omogočajo in nadzirajo gibanje. Razumevanje teorije gibalnega učenja pojasnjuje pojem motoričnega (gibalnega) programa, ki predstavlja generaliziran program, uskladiščen v spominu, ki se po potrebi dopolnjuje in prilagaja novim gibalnim problemom. Tako je potreben za npr. metanje samo en gibalni program, ki ga lahko $z$ določanjem pomembnih parametrov prilagodimo vsem možnim variacijam: met z levo ali desno roko, višje, močneje, hitreje, z rotacijo žoge ... (Tancig, 1996). Gibalno učenje je psihomotorični učni proces, s katerim se hoteno in trajno spremeni zmogljivost gibalnih spretnosti kot rezultat usmerjanja, vadbe oz. izkušenj (Edwards, 2010). Trajne spremembe v gibalnem izražanju ali vedênju prispevata tako duševni ( $p$ siho) kot tudi gibalni (motorični) sistem človeka. V praksi sicer tovrstno poimenovanje opuščamo in ga nadomeščamo s pojmom gibalno učenje. Učni izid tovrstnega poučevanja je novo znanje in védenje o različnih gibalnih strukturah. Navzven je znanje prepoznano tako, da gibanje postaja dovršeno, usklajeno, tekoče, mehko in učinkovitejše. Vzrok je v ustvarjanju novih sinaptičnih povezav. Pridobljena gibalna izkušnja se realizira kot ojačitev mednevronskih povezav (Gopnik idr., 2001). Pri gibalnem razvoju otroka ločimo med preprostim ponavljanjem gibanja in gibalnim učenjem: vsaka ponovitev gibanja še ni gibalno učenje, je pa učenje odvisno od ustreznega ponavljanja gibanja. Pri mlajših otrocih, do 6. ali 7. leta starosti, razvoj nenehno deluje v smeri izboljšanja percepcije (senzornega ali čutno-zaznavnega podsistema človeka) in motorike (lokomo- 
tornega aparata človeka) na osnovi rasti, zorenja in izkušenj, zato spodbujanje tovrstnih aktivnosti, ko govorimo o strokovnem delu vzgojitelja, imenujemo zgodnje gibalno poučevanje, ko pa govorimo o otroku, ta postopek poimenujemo zgodnje gibalno učenje. Pri tem lahko percepcijo razumemo kot prepoznavanje in razvrščanje zaznanih čutnih podatkov iz okolja, motoriko pa kot nadzorovano in ciljno usmerjeno dejavnost skeletnih mišic. Izboljšanje v delovanju ene in druge lahko vizualno prepoznamo. Percepcija in motorika sta integralno povezani, zato govorimo o senzomotoriki (Marinšek in Rajtmajer, 2017). Podobno tudi Piaget o pomenu senzomotoričnega obdobja razvoja otroka govori kot o bogatejšem simboličnem delovanju človeka. V začetku učenja so lahko uspešnejši otroci z bogatejšo sposobnostjo diferenciacije zaznav. Na praktični ravni se to kaže predvsem v boljšem vizualnem, taktilnem in kinestetičnem zaznavanju. V naslednjih fazah učenja pa so uspešnejši otroci, ki imajo obsežnejši repertoar gibalnih znanj (angl. motor knowledge) in razvitejše motorične sposobnosti (angl. motor abilities). V končni fazi lahko oboji dosežejo enako kvaliteto in kvantiteto znanj oz. gibalnih izkušenj (Marinšek in Rajtmajer, 2017). Otrok ima osnovno integralno delovanje zaznav in gibanja prirojeno, čeprav le v latentni obliki. Da bo dosegel stopnjo razvitosti senzomotoričnega sistema, bo potreboval nekajletno pomoč odraslih. Se pa otrok že kot dojenček spontano giblje v ritmu glasbe in plesa. To zmore, še predno zna govoriti in hoditi. S takšnim gibanjem se je sposoben neverbalno izražati, pri čemer ritem igra vodilno vlogo (Marinšek in Rajtmajer, 2017).

$Z$ vidika gibalnega učenja je pomembno, ali gre za učenje enostavnih ali sestavljenih gibalnih spretnosti. Tovrstno uspešno učenje zahteva hkratno uporabo večjega števila senzornih kanalov, preko katerih otrok percipira sebe in druge v prostoru in času. Najpomembnejši so vizualni, taktilni in kinestetični kanali (Rajtmajer, 1991). Hitrost učenja in kasnejše izvajanje gibanja je v tesni zvezi s stopnjo razvitosti teh kanalov, ki imajo različen pomen glede na fazo učenja gibanja: v začetni fazi učenja je najpomembnejši vizualni, postopoma pa njegovo vlogo ali del nje prevzame taktilni in kinestetični (Marinšek in Rajtmajer, 2017).

Kinestezija oz. kinestetično zaznavanje je pravzaprav povratna informacija o izvedenem gibu, brez katere ne bi bilo mogoče oblikovati zahtevnih sestavljenih gibov, kot so preigravanje z žogo, smučanje, prvine gimnastike ipd. Za kinestezijo različni avtorji uporabljajo različna imena - mišični razum, občutek za pozicijo, kinestetični vtisi -, vsem pa je skupno, da gre za določen občutek za gib (čutni vtis ali aesthesis nasproti miselni vtis ali noesis). Pri ustvarjanju občutka za gib sodelujejo elementi čutnih kanalov. 
Kot vsako učenje tudi motorični učni proces poteka preko treh spoznavnih funkcij oz. mehanizmov: (1) opazovanja, (2) mišljenja in (3) prakse oz. vadbe. Učenje gibanja je torej psihični proces, ki poleg gibalne vključuje še intelektualno in emocionalno dejavnost (Marinšek in Rajtmajer, 2017). Prepletajo se naslednje aktivnosti:

- opazovanje gibanja izzove razmišljanje in načrtovanje ponovitve gibanja, - razmišljanje izzove načrtovanje in vadbo s ponavljanjem,

- vadba, torej ponavljanje gibanja (praksa), pa izzove potrebo po ponovnem opazovanju (Marinšek in Rajtmajer, 2017).

Vse tri funkcije so potrebne za nova spoznanja, so torej vir učenja in vsaka od njih požene otroka v akcijo, le da ima zdaj en, zdaj drug, poseben ali bolj poudarjen pomen. Pri mlajših otrocih že samo opazovanje demonstriranega gibanja povzroči takojšnjo reakcijo razmišljanja in s tem željo po posnemanju, to pa je vadba, zato pri otrocih prevladuje opazovanje in posledično ponavljanje zaradi posnemanja.

$\checkmark$ začetni fazi gibalnega razvoja predstavlja gibalno učenje prepoznavanje zaznav čutil. Od hitrosti razvoja različnih čutil je odvisna hitrost pridobivanja gibalnih izkušenj, razvoj ključnih gibalnih sposobnosti, predvsem pojavnih oblik koordinacije, dinamičnega ravnotežja in splošne moči. Seveda ne smemo prezreti proprioreceptivnih zaznav in domišljije otrok, ki služi kot pomoč pri poosebljanju (personifikaciji) celostnih gibanj: skačem kot zajec ... Zato je pomembno videti vidno in ne le poslušati govorjeno, ključno za hitrost učenja gibanja: enkrat pokazati (demonstrirati) je kot stokrat povedati (Marinšek in Rajtmajer, 2017).

Filogenetske gibalne oblike so tiste, ki so omogočile človeški vrsti, da je razvila pokončno držo (npr. plazenje, hoja tek, skoki, plezanja ipd.), in so precej odvisne od okolja, v katerem otrok preživlja prva leta.

Za gibalne stereotipe velja, da se miselni mehanizmi, ki vodijo njihov proces učenja od grobe do fine izvedbe, selijo iz zavestnih možganskih središč v čelnem režnju v nižje predele, ki krmilijo ta sestavljena gibanja. Da je regulacija teh gibanj zares avtomatska, raziskovalci prepoznajo po zmanjšani aktivnosti čelnih režnjev tedaj, ko poskusne osebe izvajajo ta ista, usvojena gibanja. Zmanjšana aktivnost delov možganov, ki nadzirajo posamezno gibanje, je kazalnik avtomatizacije tega gibanja. Zavestno izvajanje zahtevnega gibanja torej kaže na začetnika (Epstein, 2015). 
Primer:

- Vizualna kontrola gibanja: hoja naprej po klinih na tleh ležeče lestve s pogledom na stopala.

- Taktilna kontrola gibanja: enaka hoja brez pogleda; otrok s stopali tipa po klinih.

- Kinestetična kontrola: otrok hodi enako naprej, vendar brez pogleda na stopalo in brez tipanja s stopali po klinih lestve. Sedaj še hodi s pravilnim dvigom noge, nagibom naprej, z ustrezno dolžino koraka in s postopnim prenosom teže.

- Utrjevanje kinestetične občutljivosti (preciznega prepoznavanja povratnih notranjih informacij) preko modificiranih osnovnih izvedb: hoja po klinih bočno, levo in desno, hoja po klinih nazaj z ali brez prvih treh vaj, hitra hoja naprej, nazaj in tek po klinih lestve (Rajtmajer, 1991).

Z obrazložitvijo koordinacije kot krovne gibalne sposobnosti, ki pravzaprav upravlja z ostalimi gibalnimi sposobnostmi, lahko nazorno predstavimo zapletenost spoznavnega procesa, odgovornega za gibanje. Genetično osnovo koordinacije predstavljajo funkcionalne značilnosti osrednjega živčnega sistema in senzorike (sprejemnikov informacij). Koordinacija je bolj kot katerakoli druga gibalna sposobnost odvisna od učinkovitega delovanja centralnega živčnega sistema (CŽS). V CŽS se namreč oblikujejo gibalni programi, s katerimi so opredeljene ravnine in amplitude gibov, hitrost in jakost njihove izvedbe ter položaji telesa v odvisnosti od zunanjih dejavnikov. Poznamo tri temeljne dejavnike za razvoj koordinacije, in sicer:

- sistem za sprejem in analizo informacij,

- center za gibalni spomin ter

- kortikalni in subkortikalni centri za oblikovanje gibanja.

Sistem za sprejem in analizo informacij: predstavlja vsa čutila, živčne poti od njih do CŽS in center za analizo informacij v njem. Ta sistem je prvi nivo, ki presoja o kvaliteti informacij iz okolja in iz lastnega telesa, tako da se lahko neko gibanje na osnovi njegove presoje programira čim skladneje in se zato tudi čim popolneje izvede. Centri za oblikovanje gibanja: informacije iz navedenih receptorjev potujejo po sprejemnih živčnih poteh v CŽS, kjer se združeno analizirajo v centru za analizo informacij (aferentna sinteza in analiza informacij). Rezultat takšne aferentne sinteze je pridobitev predstave o potrebnem gibanju ali o položaju delov lastnega telesa. Tako obdelane informacije nato potujejo v gibalne centre, kjer se ustvarjajo gibalni programi - gibalni odgo- 
vori na sprejete informacije. Kortikalni in subkortikalni centri za oblikovanje gibanja so odgovorni za oblikovanje ustreznih gibalnih programov. Realizacija gibanja: ukazi iz kortikalnih in subkortikalnih centrov za oblikovanje gibanja potujejo po eferentnih živčnih poteh (poti za odgovore) do mišic, ki realizirajo gibanje in sprožijo ustrezen odgovor na konkretne okoliščine, $v$ katerih se telo nahaja. Center za gibalni spomin: $v$ fazi analize informacij omogoča primerjavo podatkov in vnaprejšnjo eliminacijo tistih, ki niso pomembni za oblikovanje novega gibalnega programa. $V$ fazi oblikovanja novega gibalnega programa pa je pomemben tudi t. i. gibalni transfer (prenos), ki omogoča hitrejše dojemanje novih gibanj na osnovi izkoriščanja informacij iz že osvojenih gibalnih programov. Med gibalnimi programi, ki so shranjeni v centru za gibalni spomin, se namreč nenehno iščejo podobnosti z novimi gibanji, ki se jih vadeči uči. Čim več takih podobnosti se najde, hitreje in laže se je naučiti novega, do tedaj neznanega gibanja. $V$ fazi izvajanja gibanja pa center za gibalni spomin s svojo bazo gibalnih izkušenj omogoča hitro formiranje korektivnih programov gibanja $v$ subkortikalnih centrih. Pogosteje otrokom ponujamo nove gibalne naloge in gibalne probleme, pogosteje in kakovostneje bodo izvajali gibanja, ki bodo s časoma ostala trajno zapisana v gibalnem spominu. $S$ pomočjo gibalnega transferja se bodo pridobljeni gibalni programi, ki so trajno zapisani v gibalnem spominu, lahko prenesli na učenje in izvajanje druge gibalne dejavnosti

Pri gibalnem poučevanju uspešno uporabljamo prenos že znanega na neznano. To imenujemo s pojmom gibalni transfer. Ločimo lahko (Videmšek in Pišot, 2007) gibalni transfer na vertikalni prenos, ki pomeni prenos gibalnih informacij znotraj iste gibalne naloge, na lateralni prenos, kar pomeni z ene naloge na podobno nalogo, in bilateralni prenos, ki pomeni prenos $z$ leve na desno roko oz. obratno ter prenos z nog na roke oz. obratno. 



\section{PROCEDURALNI SPOMIN}

Pri učenju spretnosti in pri gibalnih/športnih aktivnostih nasploh ima osrednjo vlogo posebna vrsta spomina: »proceduralni spomin«. Z njegovo pomočjo znamo izvajati že naučeno gibanje, ne da bi se zavestno spominjali potrebnih korakov, ki smo se jih naučili. Ko z vadbo usvojimo gibanje, npr. vožnjo s kolesom, se struktura zapiše v proceduralni spomin, in že se lahko kadarkoli z lahkoto zapeljemo s kolesom, čeprav smo za učenje potrebovali veliko časa. Ker je gibanje že avtomatizirano, zanj ne potrebujemo več toliko zbranosti in ga lahko opravljamo celo brez zavestne pozornosti.

Gibalni učni proces poteka prek treh spoznavnih funkcij, ki so sklenjene v krog:

- opazovanje gibanja (analiza in načrtovanje ponovitve gibanja);

- analiza gibanja (načrtovanje in vadbe s ponavljanjem);

- vadba gibanja (praksa), ki izzove potrebo po ponovnem opazovanju.

Notranji krog upravljanja in nadzora gibanja se oblikuje postopno, z večkratnim ponavljanjem gibalne naloge. Začetna vadba gibalne tehnike in njeno ponavljanje morata biti zato kar najpravilnejši, ker se le na tak način utrjujejo kvalitativno ustrezne povratne zveze za notranje upravljanje (regulacijo) gibanja. $V$ procesu gibalnega poučevanja se namreč želi utrditi le tisto, kar ustreza ciljni predstavi o gibalni nalogi, ki se jo učenec uči. Če se v notranji krog upravljanja gibanja posredujejo neustrezne informacije (neustrezna izvedba določene gibalne naloge, nepravilna telesna drža, napačni položaji telesnih segmentov ipd.) in ne prihaja do pravočasnih popravkov (korek- 
cije) gibanja, to privede do napačne stabilizacije in avtomatizacije notranjih povratnih zvez ter s tem do neustrezno usvojenih gibalnih odgovorov oz. do napačnega poučevanja in posledično napačno naučenega gibanja. Nepravilne gibalne odgovore, ki so posledica delovanja notranjega kroga regulacije, je $v$ ustrezne in pravilne gibalne programe izredno težko preoblikovati. Človek se namreč procesov tega kroga regulacije ne zaveda, za razliko od procesov zunanjega kroga regulacije gibanja, ki se odvijajo pod nadzorom zavesti. Tako je za spreminjanje že naučenih programov gibanja potrebna faza ozaveščanja gibanja, ki zahteva velik miselni (kognitivni) napor. Ta proces pa zaradi razvojnih značilnosti pri otrocih za vzgojitelja predstavlja izredno zahtevno, odgovorno in naporno nalogo. 


\section{RELATIVNE PRIMERJAVE MOŽGANOV ALI ZAKAJ GIBALNIH PROBLEMOV NIKOLI NE ZMANJKA}

Gibalno učenje je lahko z vidika delovanja možganov zaznavanje, prepoznavanje in reševanje gibalnih problemov. Zaradi racionalnosti upravljanja $z$ energijo možgani raje delujejo na bazi relativnega in ne absolutnega primerjanja, ker bi pri slednjem porabili veliko več energije. Na področju gibanja to pomeni, da otrok ne primerja, ali je gibalni problem pri učenju zdaj rešil bolje kot kdajkoli prej, ampak rešitev primerja z rešitvami iz bližnje preteklosti. Tako problema nikoli ne reši, saj si jih ves čas zastavlja na novo. Seveda pri tem ne more oceniti svojega uspeha, napredka, ker ves čas spreminja ali pa mu vzgojitelji spreminjamo cilj njegove rešitve. Zato problemov nikoli na zmanjka, kar lahko vodi v zasičenost in izgubo motivacije. $Z$ zavestnim postavljanjem uresničljivih ciljev otrokom omogočamo, da se približajo absolutnim primerjavam, in se tako izognemo razočaranju, da niso napredovali pri reševanju gibalnega problema (cilj učinkovito zadane od blizu in ko je tarča velika, ko pa se otrok od cilja oddalji ali pa cilj zmanjšamo, ga ne zadane več, kar otroka frustrira in odvrne od nadaljnjega učenja oz. vadbe). 



\section{FAZE POUČEVANJA IN UTRJEVANJE ZNANJA O GIBANJU}

$\checkmark$ nadaljevanju predstavljamo model poučevanja in utrjevanje znanja o gibanju.

Preglednica 5: Faze poučevanja in utrjevanje znanja o gibanju

(prirejeno po Pistotnik, 2011)

\section{VLOGA UČENCA}

1. faza: površna in groba izvedba gibanja na podlagi gibalnega načrta

2. faza: osredotočanje in koncentracija na kakovostno izvedbo z opuščanjem odvečnih gibov

3. faza: avtomatizacija in stabilizacija

4. faza: modifikacija in asociacija

\section{VLOGA VZGOJITELJA/UČITELJA}

Posredovanje informacij o gibalni nalogi s prikazom

Postopno odpravljanje ključnih napak in motivacija za nadaljevanje dela

Zaključevanje optimalne izvedbe (finalizacija)

Ovrednotenje, dopolnjevanje in spreminjanje (validacija)

\section{FAZA: POVRŠNA IN GROBA IZVEDBA GIBANJA TER RAZPRŠENOST INFORMACIJ}

Peneralizacija informacij. 
Učenec se seznanja s popolnoma novo gibalno nalogo.

Prisoten je vzgojitelj, ki novo gibanje razloži in demonstrira - prikaže (izvede gibanje, pokaže film, pokaže kinograme itd.).

Učenec si ustvari predstavo, ustvari svoj gibalni načrt, shemo in formira gibalni program ter ga skuša v prvih poskusih izvesti.

Gibanje v tej fazi poučevanja je okorno, z velikim številom napak. Učenec izvaja nekatere gibe, ki so temu gibanju lastni (realni gibi), ob tem pa izvede veliko odvečnih gibov. Njegovo gibanje je tako mešanica realnih in odvečnih gibov. Učenec za izvedbo gibov (realnih ali odvečnih) porablja preveliko količino energije in se zaradi neekonomične porabe energije tudi hitreje utrudi. Zaradi želje po hitrem obvladanju gibanja učenec v prvi fazi poučevanja gibalne centre pretirano vzburja in obremenjuje. Pretirano vzburjenje osnovnega gibalnega centra energijo seva tudi na sosednje gibalne centre, ki za izvedbo gibanja niso potrebni, s tem pa povzroči njihovo vključitev in aktivacijo njim podrejenih mišic. Posledici tega sta nezavedno izvajanje odvečnih gibov in s tem dodatna potrošnja energije. Naloga vzgojitelja v tej prvi fazi je zlasti natančna in kratka tako verbalna kot vizualna in gibalna predstavitev gibanja. V zgodnjem otroštvu otroci težko sledijo razlagi in demonstraciji. Najučinkovitejša podpora v tej fazi je zato vzpostavljanje domišljijskega sveta z dobrimi zgodbami. Verbalna predstavitev se uporabi pred izvedbo gibanja kot opis gibanja in usmeritev pozornosti na bistvene elemente gibanja, med izvedbo gibanja kot kratki in jasni skrbno izbrani popravki (manj je več), lahko tudi s signali, po izvedbi gibanja pa kot nova navodila, podana glede na napake v izvedbi. Vizualna predstavitev se uporabi pred izvedbo gibanja (prikaz gibanja, film, slika, kinogram ipd.)

Vsakič popravljamo samo eno ključno napako, ki pomembno zavira izvedbo pričakovanega gibanja - ko jo odpravimo, popravimo naslednjo ključno napako.

Gibalna stimulacija se pred izvedbo gibanja uporabi kot pomoč pri namestitvi telesnih segmentov v ustrezen položaj za izvedbo in med izvedbo gibanja kot pomoč pri zadrževanju segmentov v ustreznem položaju ali pri izvedbi gibov (Pistotnik, 2011).

\section{FAZA: USMERJENO RAZLIKOVANJE, OSREDOTOČANJE VZBURJENOSTI IN KONCENTRACIJA}

Dopolnjevanje izvedbe gibanja. 
Odpravljanje odvečnih gibov in morebitnih napak pri izvedbi.

Izvedba podpornih dejavnosti za usvajanje gibanja.

Vzgojiteljeve naloge $v$ drugi fazi gibalnega poučevanja so dopolnjevanje izvedbe gibanja, popravljanje napak in motivacija učenca s ciljem zagotoviti napredek v gibalni izvedbi ter vztrajanje pri ponavljanju ustrezne izvedbe naloge. Napredek $v$ gibalni izvedbi se namreč lahko zagotovi le $z$ velikim številom ustreznih ponovitev gibanja ob sistematičnem sprotnem popravljanju napak. Popravljanje napak (korekcija) je lahko verbalno ali pa gibalno.

Verbalna korekcija napak se lahko izpelje kot:

- tekoče popravljanje napak med izvedbo gibanja; neposredno popravljanje napak takoj po končanem poskusu (upoštevati se mora hierarhija napak, začne se s korekcijo najbistvenejših);

- posledično popravljanje napak po končani vadbi s pomočjo videoposnetkov (verbalno-vizualna analiza gibanja, zaustavljanje videoposnetka $v$ kritičnih točkah izvedbe, korekcija izvedenih napak in usmeritev $v$ nadaljnje delo).

Prav tako je treba spodbuditi in ohraniti motivacijo za izvajanje gibalnih dejavnosti. Vzroki padca motivacije za vadbo so lahko:

- utrujenost zaradi velikega števila ponovitev gibalne naloge;

- zasičenost s ponavljanjem naloge;

- nezavedni vplivi različnih gibalnih nalog, ki se jih vadeči uči hkrati in druga na drugo vplivajo negativno;

- prekinitev napredovanja pri osvajanju pravilne izvedbe gibanja (plato gibalnega poučevanja).

\section{FAZA: AVTOMATIZACIJA (SAMODEJNO DELOVANJE PROCESOV) IN STABILIZACIJA (USTALITEV, UTRDITEV GIBALNIH PROGRAMOV)}

\section{Avtomatizacija}

Izvedba gibanja postaja pri učencu v tretji fazi gibalnega poučevanja vedno bolj tekoča. Gibanje se avtomatizira in poteka lahkotno, ker se gibalne faze kompleksnih gibanj med seboj zelo hitro povezujejo, saj ni več potrebe po zavestnem nadzoru izvedbe. Pojavljajo se le realni gibi, saj se $v$ gibanje vključu- 
jejo samo za izvedbo potrebne mišične skupine, ostale pa so sproščene. Energija za izvedbo gibanja je natančno odmerjena, sčimer je gibanje popolnoma racionalizirano.

\section{Stabilizacija}

Učenec je na osnovi njihovih informacij sposoben sam prepoznavati napake in jih korigirati, ne da bi zavestno (miselno) spremljal svoje gibanje ali dobival informacije iz okolice. Vodenje gibanja je v osnovi treba popolnoma prepustiti notranjemu krogu regulacije, saj bi močnejše vključevanje zunanjega kroga lahko zmanjšalo hitrost in usklajenost izvedbe. Procesi v gibalnem korteksu so namreč stabilizirani (utirjeni, ustaljeni) in zunanje informacije se lahko $v$ tem primeru pojavijo tudi kot motnje za optimalno izvedbo gibanja.

Vzgojiteljeva naloga je, da skuša odpraviti vse napake, pa naj bodo še tako majhne, in razširiti gibalni program z dodatnimi informacijami (finalizacija).

Za dosego popolne avtomatizacije gibanja mora vzgojitelj v tretji fazi uporabiti vadbo v oteženih pogojih (Pistotnik, 2011):

- $\quad$ z večjo hitrostjo;

- $\quad z$ večjo močjo;

- $\quad z$ večjo natančnostjo $v$ gibanju;

- v neobičajnih pogojih itd.

\section{FAZA: MODIFIKACIJA (PRILAGAJANJE, DOPOLNJEVANJE GIBANJA) IN ASOCIACIJA (ZDRUŽEVANJE SPOMINSKIH INFORMACIJ) TER USKLAJEVALNI PROCES}

\section{Modifikacija}

$S$ pridobivanjem izkušenj začne učenec prilagajati naučeno gibanje svojim sposobnostim in značilnostim. Razvijati začne osebni slog v izvedbi gibanja. Proces dograjevanja in prilagajanja gibanja (modifikacije) ni nikoli zaključen.

\section{Asociacija}

Gibalni program se dopolnjuje na osnovi asociativnih povezav z že znanimi gibalnimi programi, shranjenimi $v$ centru za gibalni spomin (asociacija).

Usklajevanje ali koordinacija

Struktura koordinacije je sestavljena iz: 
- sposobnosti realizacije celostnih programov gibanja;

- sposobnosti porabe gibalnih informacij;

- sposobnosti gibalnega reševanja prostorskih problemov;

- sposobnosti gibalne realizacije ritmičnih struktur;

- sposobnosti pravočasne izvedbe gibanja (»timinga«);

- sposobnosti koordinacije spodnjih okončin - topološka pojavna oblika.

Po Pistotniku (2011) je zmožnost realizacije celostnih programov gibanja sposobnost, ki omogoča, da se neka gibalna naloga zazna kot celota in se kot celota tudi izvede. Gre za gibalne strukture, ki so biomehansko natančno določene in je z njihovo pravilno izvedbo pogojeno doseganje optimalnih rezultatov. Vadeči jih morajo natančno izvesti in so usvojene osnova za poučevanja novih, praviloma zapletenejših gibalnih nalog.

Sposobnost porabe gibalnih informacij je opredeljena s količino in kakovostjo gibalnih informacij, ki so avtomatizirane in shranjene $v$ centru za gibalni spomin (več gibalnih informacij kot bo človek usvojil v rani mladosti, širšo gibalno bazo bo imel). S prenosom že avtomatiziranih gibalnih informacij v postopek poučevanja novih gibanj se ta postopek olajša in pospeši. Gibalne asociacije, ki se samodejno pojavljajo, so del novega gibanja, podobnega že znanim in usvojenim gibanjem.

Sposobnost gibalnega reševanja prostorskih problemov je sposobnost učinkovitega obvoda motečih dejavnikov - ovir v nekem osnovnem gibanju, s hitrim oblikovanjem korektivnih programov gibanja. Sposobnost se izrazi pri reševanju gibalnih problemov, ki se pojavijo ob realizaciji že naučenega osnovnega gibanja, povezanega s premikanjem v prostoru (Pistotnik, 2011).

\section{Primer: tek v naravi}

Osnovno gibanje je tek v gozdu (za to obstaja osnovni gibalni program, ki je avtomatiziran). Na poti se pojavi jarek (fizična ovira), ki ga z običajnim programom teka ne bo mogoče preiti. Na osnovi vidnih informacij iz okolja se oblikuje ustrezen korektivni program gibanja (prek ali mimo ovire ipd.), s katerim se skuša premagati oviro. Ko je ta premagana, se korektivni program zaključi in se gibanje nadaljuje z osnovnim gibalnim programom do nove spremembe.

Ker ostanejo pridobljeni gibalni programi trajno zapisani v gibalnem spominu, je pomembno, da ima otrok dostop do okolja, $v$ katerem bo pridobil čim več gibalnih informacij in možnosti kakovostnega reševanja gibalnih problemov, s katerimi bo lahko učinkovito razvijal svoje prirojene gibalne sposobnosti ter na drugi strani oblikoval nove gibalne programe in vzorce gibalnega vedenja. Pri tem igrajo pomembno vlogo tudi spoznanja o vplivanju in delo- 
vanju gibalnega transferja, ki nam omogoča, da gibalne informacije z naučene gibalne dejavnosti prenesemo na učenje in izvajanje druge gibalne informacije oz. dejavnosti.

Vloga gibalnega transferja je lahko tudi negativna in zavira ali onemogoča gibalno učenje - tudi zaradi morebitnih napak v že usvojenih gibalnih programih. 


\section{NAPAKE PRI POPRAVLJANJU NAPAK}

Vzgojiteljevo razumevanje in njegov odnos do napak je pomemben kazalnik kakovostnega gibalnega poučevanja. Uvodoma opozarjamo med pojmovanjem napake in posameznikom, ki je naredil napako. Razlika je v tem, da je napaka predvsem postopek, ki ga je posameznik izpeljal, in ne predstavlja posameznika. Zato otrok, ki je napako naredil, ko je slabo oz. napačno izvedel gibalno nalogo, še ne pomeni, da je pri gibanju slab. Otroci v zgodnjem otroštvu še ne ločijo sebe od svojega ravnanja, kar velja tudi pri delanju napak, zato se lahko poistovetijo $z$ napako in se prepoznajo kot neuspešne, neprimerne, nespretne, nerodne ... Vzgojiteljeva vloga je, da otroku pojasni, da je dober, ampak da še ni dobro naredil nekaterih (konkretnih!) gibalnih nalog. Zato ga usmerimo, da loči sebe od svojih ravnanj, se posveti spoznavanju, česa še ni dobro naredil, in si prizadeva ugotovljene ključne napake popraviti. Skozi popravljanje pri gibalnem učenju otroku izkazujemo spoštovanje in ga cenimo, hkrati pa ga opozarjamo na gibalne napake s ciljem, da jih odpravi. V primeru, ko je s svojo napako povzročil škodo, ga spodbujamo, da se za svoje dejanje opraviči in napak ne ponavlja več. 



\section{IZHODIŠČA ZA UČINKOVITO GIBALNO POUČEVANJE}

Izhodišča za učinkovito poučevanje (preglednica 6) lahko predstavimo kot razumevanje realnih pričakovanj učencev in zmogljivosti učitelja in učnega okolja. Temeljiti mora na realni oceni njihovega predznanja ter sposobnosti in motiviranosti. Učitelj pri tem uporablja postopke usklajevanja, pomoči, poenostavitve in prilagoditve.

\section{Preglednica 6: Izhodišča učinkovitega poučevanja}

Razumevanje realnih pričakovanj učencev ter zmogljivosti vzgojitelja in učnega okolja Ocena njihovega predznanja, sposobnosti in motiviranosti

Poenostavitve, pomoč in prilagoditve.

$\checkmark$ središču pedagoškega procesa je učenec - usmerjenost v razvoj njegove učinkovite gibalne kompetentnosti in v zadovoljstvo učenca $\mathrm{z}$ upoštevanjem pravil stroke

Zagotavljanje celovite podpore učencem pri oblikovanju zdravega življenjskega sloga

Paradoks gibalnega poučevanja: najprej od učencev zahtevamo popolni hoteni in zavestni nadzor gibanja, kasneje pa, da nadzor čim prej opustijo in gibanje povsem avtomatizirano izvajajo (vožnja s kolesom). $V$ možganih delujejo številni centri, ki med seboj sodelujejo. Za razumevanje gibanja je pomemben zlasti gibalni center, ki se nahaja v korteksu. Bazalni gangliji in korteks so povezani $v$ zanke tako, da informacije iz korteksa prihajajo $v$ bazalne ganglije in iz bazalnih ganglijev znova nazaj v korteks. Za naše razumevanje gibanja je najpomembnejša neposredna povezava med bazalnimi gangliji in 
korteksom, ki se imenuje motorična zanka in kontrolira gibanje. Bazalni gangliji nam omogočajo, da naučene gibe shranimo kot gibalne vzorce in jih samodejno, ne da bi mislili nanje, izvajamo - ko se npr. naučimo voziti kolo, ga lahko samodejno vozimo kadarkoli! 


\section{KRATEK PREGLED GIBALNEGA POUČEVANJA V ZGODNJEM OTROŠTVU V SLOVENIJI}

Področje zgodnjega gibalnega poučevanja so v slovenskem prostoru v novejši zgodovini poglobljeno preučevali redki znanstveniki in pedagogi. Prepoznavni so predvsem Rajtmajer (1991), Tancig (1996), Strmčnik (2001), Videmšek in Pišot (2007), Novak, Kovač in Čuk (2008), Škof (2017), Pistotnik (2011) in Retar (2017).

Rajtmajer (1991, str. 23) navaja, da je treba zlasti zaradi hitrega razvoja procesa zgodnjega gibalnega poučevanja in njegovega uveljavljanja $v$ praksi »konkretizirati vse elemente specialne didaktike, ki so nujni za uspešno vodenje psihomotoričnega procesa $v$ predšolskem obdobju: načela, metode, oblike, tehnike, organizacijo in izvedbo učno-vzgojnega procesa, klasifikacijo vsebin, planiranje, priprave in postopke za preverjanje znanja in sposobnosti otrok«. Velik poudarek daje uveljavljanju didaktičnih načel, ki jih razume kot "vodilo, pravilo, odnosno smernico za delo, zaradi katere je vzgojitelj pri svojem delu kar najbolj uspešen « (Rajtmajer, 1991, str. 147). Med načeli, ki jih navaja, je z našega vidika sodobnega načina avtomatiziranega življenja zanimivo načelo interesa, doživljajev in motivacije otroka. »Usmerjenost $k$ določenim gibalnim dejavnostim, s katerimi rešujemo konkretne gibalne probleme ali premagujemo ovire, in čustvena determiniranost sta danes še aktualnejši. Otroci namreč zelo hitro preusmerjajo svojo pozitivno čustveno naravnanost od gibanja k drugim dejavnostim, če je gibalni problem prelahak ali pa pretežak zanje!« (Rajtmajer, 1991, str. 152). Rajtmajer (1991) zagovarja usklajenost informacijske (gibalno učenje) in energetske (gibalne razvedrilne igre) komponente zgodnjega gibalnega poučevanja ter daje velik poudarek čustvenemu in socialnemu pristopu gibalnega poučevanja, saj gibalno učenje do petega leta 
starosti razume predvsem kot pridobivanje izkušenj po načelih ugodja. Otrok si namreč ne želi zapustiti svoje »cone ugodja«, zato takoj, ko gibalna igra zanj postaja prezahtevna, svojo pozornost preusmeri drugam. Strmčnik (2001) poudarja koristi »pozitivne podkrepitve«, ki lahko poveča dejavnost in vztrajnost otrok, pospešuje delovni tempo, zmanjšuje pozabljanje, povečuje zanimanje in veselje do poučevanja. Tancig (1996) ugotavlja, da je gibalno učenje odvisno od mnogih dejavnikov in ne narašča samo s številom ponovitev; odvisno je namreč tudi od variabilnosti in pestrosti vadbe, s čimer poda smernice razvoja inovativnosti v gibalnem poučevanju. Priporoča uporabo različnih materialov, izvajanje gibalnih nalog z različnih razdalj, z različnimi hitrostmi in velikostmi. Ušaj (2003) gibalno učenje opredeljuje kot proces pridobivanja, izpopolnjevanja, stabilizacije in uporabe gibalnih programov v centralnem živčnem sistemu, v nasprotnem primeru jih je treba z vadbo zgraditi in shraniti, ter nakaže, da je bistvo gibalnega poučevanja ustvarjanje gibalnih programov. Novak idr. (2008) priporočajo izbiranje takih gibalnih dejavnosti, ki so prilagojene zlasti zmožnostim otrok ter materialnim in drugim pogojem. Po Pistotniku (2011) je gibalno učenje proces postopnega prilagajanja gibalnega ustroja na racionalno izvedbo novega gibanja. Rezultat gibalnega poučevanja so gibalne spretnosti oz. gibalna znanja (izvedba motoričnih informacij), ki se pojmujejo kot z učenjem pridobljene osnove za pravilno izvedbo gibalne dejavnosti.

Pistotnik tako poudarja usmeritev k racionalnosti in kakovosti izvajanja gibalnih dejavnosti. Glede tega, v kolikšni meri se bodo otrokove zmožnosti za kakovostno izvedbo gibalnih dejavnosti v prihodnje razvile, pa Pišot in Planinšec (2005) ugotavljata, da je to odvisno od otrokove lastne dejavnosti in okolja, ki nanj vpliva. Slednje je lahko glede izkušenj, ki mu jih ponuja, zelo bogato ali revno. Prve spodbude, ki jih je otrok deležen, so za njegov nadaljnji razvoj izjemno pomembne. Spodbudno okolje otroka motivira k razvoju, medtem ko lahko revno okolje z vidika izkušenj njegov razvoj celo zavira (Pišot in Planinšec, 2010).

Gibalna učinkovitost poteka v stalni soodvisnosti vseh dimenzij psihosomatskega statusa. Izražanje (manifestacija) vseh človekovih dejavnosti je gibalno (motorično) in se kaže kot gibanje celega telesa, gibanje posameznih telesnih delov, kot drobne gibalne spretnosti ali govor (Plevnik, 2014). Gibalna obravnava pa je celostna obravnava posameznika z vsebinami in sredstvi gibanja in gibalne učinkovitosti, upoštevajoč zmožnosti, posebnosti in omejitve posameznika, ki ga gibalno opredeljujejo v interakciji z okoljem. V literaturi večkrat zasledimo izraz »motoričen«. V tem pomenu (npr. motorične sposobnosti, motorična spretnost, motorično učenje, motorična naloga itd.) izraz pomeni slovensko sopomenko gibanja (gibalne dejavnosti) in jo v tem pome- 
nu tudi razumemo (npr. gibalne sposobnosti, gibalna spretnost, gibalno učenje, gibalne kompetence, gibalna naloga itd.). Zgodnje gibalno poučevanje je model, ki omogoča izvedbo tako spontanih kot skrbno načrtovanih gibalnih nalog s ključnim ciljem, da pomembno pripomorejo tako k uspešnemu razvoju gibalnih sposobnosti otroka kot k usvajanju elementarnih gibalnih vzorcev in gibalnih stereotipov.

Učenje gibanja je del procesa poučevanja. Tako vsako učenje gibanja $v$ svoji začetni fazi zahteva tudi miselni (kognitivni) napor, ki pa ga lahko vzgojitelj z izbiro ustreznih vaj, oblik in metod dela prilagaja razvojni stopnji učencev. Gibalno učenje predstavlja proces postopnega prilagajanja gibalnega ustroja na racionalno izvedbo novega gibanja (Pistotnik, 2011). Rezultat gibalnega poučevanja je razvoj gibalnih sposobnosti oz. usvajanje novih gibalnih znanj in spretnosti (realizacija gibalnih informacij), ki se pojmujejo kot z učenjem pridobljene osnove za pravilno izvedbo gibalne naloge in se $v$ interakciji z okoljem izražajo kot gibalno vedenje oz. gibalno obnašanje (Pišot, 2012; Plevnik, 2014). Na izvedbo procesa gibalnega poučevanja vplivajo notranji (telesne značilnosti, gibalne sposobnosti, kognitivne in konativne lastnosti) in zunanji dejavniki, med katere se uvrščajo materialne možnosti, naravne danosti in znanje o športu oz. izvedbi gibanja (Pistotnik, 2011). Gibalno učenje temelji na usposabljanju otrok za učinkovito reševanje gibalnih problemov. Pri tem uporabljajo predvsem konkretno, konvergentno in divergentno obliko razmišljanja. Za konkretno reševanje gibalnih problemov, ki najprej nastopi v zgodnjem otroštvu, je značilno, da v otrokovem miselnem procesu prevladuje zlasti uporaba zaznav, predstav in konkretnih gibalnih pojavov (otrok prime žogo). Pri konvergentnem gibalnem učenju prevladuje ena ali več pravilnih rešitev gibalnega problema, ki temelji(jo) na predhodnem znanju in izkušnjah (otrok poda žogo z obema rokama ali tudi samo z eno roko najbližjemu otroku v skupini). Divergentno reševanje gibalnih problemov pa vedno zaznamuje več možnih pravilnih rešitev, ki so lahko neobičajne in nepričakovane ter presegajo predhodno gibalno znanje (otrok lahko poda žogo kateremukoli otroku v skupini in na kakršenkoli način). Pri učinkovitem poučevanju otrokom nikoli ne povemo rešitev (Graham, 2001), seveda pa jih pohvalimo, ko najdejo rešitev. Za divergentno reševanje zastavljamo vprašanje: »Na katere tri načine lahko rešimo ...?« Usvajanje gibalnih nalog izvajamo po načelu postopnosti. Gibalna dejavnost mora biti izbrana in vodena tako, da v vseh učencih krepi občutke samozavesti, zaupanja vase, radosti in zadovoljstva. Varnost med dejavnostjo je osnovna skrb vzgojitelja, prikazovanje vaj ali prikaz gibanja pa je nujen sestavni del dejavnosti. Ob izvajanju določenih vaj upoštevamo, da nekatere gibalne dejavnosti zahtevajo veliko število natančnih ponovitev in 
da najprej popravljamo grobe nepravilnosti, s ponavljanjem in z utrjevanjem pa odpravljamo tudi druge napake. Priporočilom lahko dodamo še vzpostavljanje prijaznega in pozitivnega učnega okolja, primerno komuniciranje in spodbujanje ter ustrezno nagrajevanje. Za učinkovito učenje je pomembno, da vzgojitelji zagotavljamo pozitivno, varno in ustvarjalno okolje, v katerem je veliko raznolikih praktičnih vsebin (Retar idr., 2014). 


\section{MOTIVACIJSKI DEJAVNIKI GIBALNEGA/ ŠPORTNEGA UDEJSTVOVANJA}

Ko govorimo o tem, kaj nas usmerja, da nekaj bodisi naredimo ali opustimo, govorimo o motivaciji, ki jo lahko opredelimo kot zapleten psihološki proces, ki spodbuja in usmerja naše vedenje in ravnanje.

$\checkmark$ izvedbo še tako preprostega ali zelo zapletenega giba je namreč treba vložiti veliko energije, zato je motivacija pri gibanju v ospredju. Motivacija povzroča in usmerja naše delovanje. Privede nas do tega, da nekaj naredimo ali ne naredimo, in je psihološki proces, ki deluje v interakciji, se spreminja in človeku omogoča njegovo neponovljivost ter je usmerjen $\mathrm{k}$ ali proti nekemu ciljnemu objektu. Na delovanje vplivajo tako notranje kot zunanje spodbude oz. motivi, zato ločimo notranjo in zunanjo motivacijo tudi pri gibalnem poučevanju. Motivacija vpliva na vedenje zaradi različnih spodbud in usmerjanj, zato predstavlja pomembno orodje vzgojitelja pri gibalnem poučevanju in učenju. Zadovoljstvo, ugodje, sreča ... so trženjski pojmi, ki niso vedno in povsod združljivi s pedagoškim pojmovanjem pozitivne učne izkušnje otroka. Otroci se bodo, ko bodo lahko izbirali med tem, kaj je za njih dobro in prav ter kaj je za njih ugodno, raje večkrat odločili za slednje. Zato moramo učitelji vsakič znova najti motive, ki bodo pri otrocih sprožali motivacijo za to, da bodo naredili to, kar je prav, in ne, kar jim je všeč! 


\section{PRESEGANJE OTROKOVE CONE UDOBJA KOT MOTIVACIJSKI PRISTOP VZGOJITELJA}

Kako delujemo? Za prispodobo lahko uporabimo uveljavljeno razlago treh con: udobja, optimalnosti in nevarnosti (White, 2009). Temeljna človekova potreba je varnost. Zato se najraje zadržujemo v coni udobja, v kateri se počutimo varno, prijetno, sproščeno, to pa zato, ker je za ta status občutka značilna relativno nizka raven stresnih hormonov. Ko otrok deluje v coni udobja, opravlja vse gibalne storitve rutinsko in uporablja omejen nabor gibov ter gibalnih struktur, kar zagotavlja stabilno raven gibalne učinkovitosti brez novih znanj, nevarnosti, vznemirjenja ..., zato $v$ tej coni gibalne dejavnosti zanj ne predstavljajo dodatnih obremenitev, ki so predpogoj za učinkoviti gibalni razvoj in napredek v gibalni storilnosti. Z vidika pozitivnih razvojnih vplivov je najprimernejše delovanje $v$ coni optimalnosti, kjer na področju gibanja ne prevladuje rutina in še ni prevelike nevarnosti oz. tveganj za poškodbe, ki lahko zavirajo gibalni razvoj v zgodnjem otroštvu. Prehod iz cone udobja v optimalno cono delovanja je pogosto povezan s strahom pred spremembami, z negotovostjo, otroci se lahko počutijo ogrožene, zato jih moramo vzgojitelji pri vstopanju v novo gibalno okolje podpirati tako s primernimi didaktičnimi metodami, učnimi oblikami in postopki kot tudi z zunanjo motivacijo.

\section{NOTRANJA IN ZUNANJA MOTIVACIJA PRI GIBALNEM POUČEVANJU}

Notranja motivacija je prirojeno, torej naravno nagnjenje k razvoju naših sposobnosti prek poučevanja, za katerega ni potrebna nikakršna zunanja spodbuda (nagrada, priznanje, pohvala, nadomestilo itd.). Ko smo notranje motivirani, ne potrebujemo zunanjih ciljev in spodbud, zadošča pripravljenost po gibanju, ki pa lahko razmeroma hitro upade, zato je zelo pomembno vzgojiteljevo vključevanje elementov zunanje motivacije. Notranjo motivacijo lahko razložimo s čustvenim modelom, pri katerem je npr. čustvo zanosa vodilo, da nas sama gibalna aktivnost motivira, ker v njej uživamo in uresničujemo cilj, da s svojimi gibalnimi sposobnostmi rešimo gibalni problem, premagamo postavljeni izziv, izboljšamo prejšnji izid ...

Zunanjo motivacijo predstavljajo motivacijske spodbude, ki izhajajo iz okolja in so posredne, saj jih uporablja nekdo zunanji (starši, vzgojitelji, vrstniki, mediji, oglaševalci itd.), da bi z njimi sprožil motivacijski proces. Takrat delu- 
jemo zaradi zunanjih vzrokov, bolje rečeno, posledic, ki sledijo našemu delovanju (pohvala, spodbuda, nagrada, priznanje oz. uresničitev naših ciljev itd.). Povečanje motivacije pri gibalnem poučevanju lahko dosežemo z ustrezno izbiro didaktičnih postopkov (prirejeno po Pistotnik, 2011):

- reorganizacijo dela v različnih skupinah, spremembo prostora (okolja) in olajšanjem vadbe, spremembo metode dela (uporaba igralnih oblik);

- rabo privlačnih in otrokom všečnih didaktičnih pripomočkih in učilih;

- pohvalo uspešne izvedbe - biti pozoren na delo učenca in opaziti uspehe (ne dvigati motivacije $z$ lažno pohvalo);

- seznanitvijo učencev z zakonitostmi gibalnega poučevanja - pojavljanje platoja gibalnega poučevanja, ko število ponovitev raste, kakovost pa ne, vendar se napredek $v$ gibalnem izrazu ponovno pojavi.

Motivacijski dejavniki gibalnega/športnega udejstvovanja (prirejeno po Gill, 2000):

- usvajanje novih gibalnih znanj - radovednost;

- napredek $v$ gibalnih sposobnostih in $s$ tem prehod na višjo raven - vedoželjnost;

- izboljšanje gibalne pripravljenosti, učinkovitosti in storilnosti - raziskovanje;

- izziv (biti izzvan in/ali izzvati) - biti boljši;

- druženje, zabava in razvedrilo - ohranjanje cone ugodja;

- skrb za ohranitev in izboljšanje počutja oz. zdravja.

\section{TEKMOVANJE IN IZLOČANJE KOT MOTIVACIJA?}

v zgodnjem otroštvu je uporaba igralne oblike tekmovanja kot modela poučevanja in ponavljanja že naučenih gibalnih vzorcev, namenjena izključno tekmovanju s samim seboj in nikakor ne s sovrstniki. Zato priporočamo, da pri igrah, ki vključujejo tekmovanje, zlasti tiste vsebine, ki temeljijo na izločanju otrok, opustimo klasično izločitev otroka, ki je »izgubil« in zato »izpadel« iz igre. Otroku ponudimo drugo prilagojeno gibalno vsebino in tako prispevamo $\mathrm{k}$ večji učinkovitosti in zmanjševanju morebitnih negativnih psiholoških vplivov, ki so lahko posledica izločanja, izpadanja, »kaznovanja«. Otroci se tako lažje spoznavajo s porazom, naučijo se obvladovati jezo in premagujejo strah pred neuspehom ter uspehom. Mehak prehod $v$ tekmovalne oblike in razvrščan- 
je se priporoča šele med desetim in dvanajstim letom starosti. Do takrat pa naj vse gibalne/športne dejavnosti temeljijo izključno na igri in tekmovanju, kjer ne določamo zmagovalcev in poražencev, prav tako ne razvrščamo otrok na prvega, drugega, tretjega ... zadnjega. Pri slednjem gre za t. i. tekmovalni šport, ki ga lahko pojmujemo kot visoko strukturiran in na strogih pravilih temelječ sistem gibalne aktivnosti s tekmovalnimi cilji in s poudarkom na premagovanju tekmecev, doseganju rekordov in všečnosti gledalcem, navijačem.

Povzamemo lahko, da je najboljša praksa spodbujanje potrditev od znotraj, torej iz otroka, in ne spodbujanje k iskanju zunanje potrditve; otrok naj ne bo dober, ker je dobro ali prav oz. najbolje izvedel neko gibalno nalogo, ampak ker je pri gibanju užival, raziskoval, odkrival svoje zmožnosti ter sposobnosti, se razvijal. 


\section{KOMUNICIRANJE KOT PODPORA GIBALNEMU UČENJU}

Komunikacija je proces, s katerim sporočevalec posreduje informacije prejemniku s ciljem, da je njegov želeni pomen sporočanja razumljen. Za vzgojitelje je komuniciranje zelo pomembno in odgovorno orodje za zagotavljanje učinkovitosti ter zlasti varnosti izvedbe programov, saj gre za načrtovani proces, s katerim posredujemo informacije prejemniku s ciljem, da oblikujemo najprimernejše način, pristop in obliko sporočila, in ki bo razumljen s čim manjšimi šumi in napakami. Zaradi specifik zgodnjega gibalnega poučevanja ga velikokrat nadgradimo in dopolnimo $z$ demonstracijo gibanja in zgodbo, ki otrokom olajša razumevanje, kaj in kako morajo izvesti gibalne naloge.

Vzgojiteljev cilj je s komunikacijo vzpostaviti stik in odnos z otrokom, da bo $z$ veseljem sodeloval z njim pri uresničevanju gibalnih ciljev in ne zgolj ubogal oz. izpolnjeval vzgojiteljeva navodila, ukaze, naloge. Gibalno učenje ni ukazovanje, ampak sodelovanje pri iskanju najboljše poti do kakovostnih gibalnih vzorcev.

\section{VRSTE KOMUNICIRANJA}

Komuniciranje delimo na verbalno (zlogi, besede, povedi) in neverbalno, ki prispeva več kot polovico informacij: 
- govorica telesa: geste, telesna drža, obrazna mimika, očesni kontakt, dotik;

- govorica glasu: barva, ton, ritem, mašila, ostrina, tresenje, jecljanje, kričanje;

- govorica bližine: neposredna bližina, dotik, manipulacija, prikaz gibanja;

- govorica videza: telesni videz in vonj, urejenost, obleka, modni in drugi dodatki, celostna podoba - prikriti kurikulum.

\section{ZNAČILNOSTI UČINKOVITE KOMUNIKACIJE}

Zaradi nerazumevanja sporočila je lahko učenec izpostavljen večjemu tveganju za nastanek poškodbe, ker napačno izvede gibalno nalogo in si s tem lahko povzroči poškodbe.

Učinkovita in uspešna je komunikacija takrat, ko je zagotovljena skladnost verbalnega in neverbalnega komuniciranja. Oblikujete jasna vprašanja in kratke odgovore, komunikacija naj bo enostavna in jedrnata, sporočila enopomenska, skladna, osredotočenost naj bo na bistvo, komunikacija naj temelji na etičnosti, integriteti ter naj bo transparentna. Vsak izhod iz komunikacijskega kroga naj povezuje učinkovita povratna informacija. Komunikacijo z otroki pri gibalnem poučevanju dopolnite $z$ demonstracijo gibalnega vzorca ali gibanja, z zgodbo, uporabite glasbo in učna pomagala, ki podpirajo sporočilo.

Priporočila za učinkovito komuniciranje v športu (prirejeno po Martens, 1997) obsegajo:

- direktnost,

- osebni pristop,

- etičnost in korektnost,

- jasnost in konsistentnost,

- ločitev dejstev od vašega mnenja,

- fokusiranje na eno stvar,

- takojšnja sporočila,

- sporočila brez skritih pomenov,

- podpiranje sogovornika,

- skladnost verbalne in neverbalne komunikacije,

- večkratno ponavljanje svojih in sogovornikovih sporočil,

- prilagodljivost glede na prejemnika sporočila,

- preverjanje povratnih informacij glede razumevanja sporočila. 
Pomen sporočila vedno določi prejemnik, v našem primeru otrok, zato vedno uporabimo preverjanje, kako so otroci razumeli naše sporočilo, in šele potem nadaljujemo bodisi s dopolnili sporočila ali pa z nadaljnjimi načrtovanimi aktivnostmi.

\section{SMERNICE ZA KAKOVOSTNO KOMUNICIRANJE PRI GIBALNEM POUČEVANJU}

\section{Varnost}

Zaradi nerazumevanja sporočila je lahko uporabnik izpostavljen večjemu tveganju za nastanek poškodbe, ker napačno izvede gibalno nalogo in si s tem lahko povzroči poškodbe.

\section{Všečnost}

Otroku je smiselno ponuditi všečno organizirano storitev, ki jo doživlja kot prijetno gibalno uporabniško izkušnjo, s katero uresniči svoja pričakovanja!

\section{Prilagoditev}

V fazi uveljavljanja najustreznejših metodičnih korakov pri gibalnem učenju iščemo najprimernejše prilagoditve, da bo učenje učinkovitejše. Pri tem moramo znati otroku prepričljivo pojasniti shemo prilagoditve, da jo bo lahko usvojil.

\section{Poenostavitev}

Z ustrezno komunikacijo lahko otroku učinkovito pojasnimo sheme poenostavitve izvajanja zahtevne gibalne storitve $v$ sklopu gibalnega učenja, zlasti v fazi popravljanja napak.

\section{Rezilientnost - vzdržnost}

Pri gibalnem učenju pedagogi z didaktičnega zornega kota za dvig rezilientnosti skrbimo tako, da oblikujemo varno, spodbudno in skrbno učno okolje, ki učencu postavlja uresničljive cilje, zagotavljamo ustrezno pomoč in podporo, razvijamo ključne vseživljenjske kompetence ter omogočamo aktivno participacijo učenca. 
Komuniciranje v gibalnem učenju posega tudi na področje izvajanja pomoči uporabniku:

- spodbuda,

- usmeritev,

- preusmeritev,

- podkrepitev,

- osmislitev,

- usvojitev učnega cilja,

- evalvacija ter

- refleksija.

\section{Nevrofiziologija učinkovitega učenja v povezavi s strahom}

Strah pri učenju lahko zelo negativno vpliva na učenje in pomnjenje. Informacije o strahu posreduje amigdala v možganih, ki zaznava in prepoznava elemente strahu. Posledično se možgani (center amigdala) zato preusmerijo na iskanje strategij preživetja in se prenehajo ukvarjati z učenjem in s pomnjenjem. Zagotavljanje mirnega učnega okolja tudi z mirno, prijazno, razumevajočo komunikacijo je zato zelo pomembno.

Za učinkovito komuniciranje na področju zgodnjega gibalnega poučevanja se lahko naslonimo tudi na naslednje oporne točke:

- Sem vzpostavil stik z otrokom, ki omogoča sodelovanje pri izpolnjevanju pričakovanj in ni samo ukazovanje, kaj mora ali česa ne sme narediti?

- Kaj je cilj sporočila?

- Kako sem bil razumljen?

- Sem sporočilo podkrepil s kakovostno demonstracijo, zgodbo, didaktičnimi pripomočki?

- Bi me lahko razumeli tudi drugače?

- Sem bil dovolj dosleden in jasen v svojih zahtevah, da sem dosegel cilj?

- Bi cilj lahko dosegel še kako drugače - učinkoviteje, prijazneje? 


\section{POMEN KAKOVOSTNE IN PREGLEDNE DEMONSTRACIJE/PRIKAZA GIBANJA}

Pomen demonstracije ali, bolje, prikaza pri gibalnem učenju je v celostnem, natančnem in nazornem prikazu izvedbe gibalne storitve.

Vzgojitelj najprej razloži, kaj bodo otroci delali, otroci poslušajo in s pomočjo spoznavnih procesov dojemajo učne snovi na podlagi slušnih zaznav. $\checkmark$ nadaljevanju vzgojitelj s prikazom, predstavitvijo oz. demonstracijo prikaže (demonstrira) gibanje, otroci pa pri tem opazujejo in dojemajo učno snov na podlagi vidnih zaznav. Kombinacija slušne in vidne zaznave, ki ji sledi še gibalna zaznava, ko otrok gibanje poskusi izvesti sam, omogoča učinkovito gibalno učenje.

Z demonstracijo otroci dojemajo elemente objektivne stvarnosti, to je dejstva. Prikaz gibanja namreč v teoriji pouka pomeni prikazovanje gibanja, ki ga je mogoče perceptivno doživeti, zaznati s čutili.

Učitelj prikazuje, učenci gledajo in opazujejo, kar spodbuja miselne procese in ne zgolj posnemanje. Prikaz naj bo nazoren. Večkrat posebej poudarimo pomembne stvari. Pomemben je tudi prikaz napak v gibanju, ki ima vlogo povratne informacije. Omogoča namreč korekcijo gibanja oz. odpravljanje napak.

Prikaz je lahko neposreden - pokaže ga vzgojitelj - ali posreden - gibanje pokaže eden od otrok ali ga prikažemo prek medijev: slik, filma, skic ...

Ključna vloga demonstracije je $v$ tem, da učencu omogoči skladno predstavo o gibanju, ki se ga želi naučiti, in mu tako olajša gibalno učenje. Učenec si s pomočjo videne demonstracije gibanja ustvari svojo lastno mentalno shemo gibanja, ki jo kasneje uporabi, ko poskuša gibanje ponoviti sam s svojim tele- 
som in umom - to je gibalno učenje. Pomen ima tudi pri naprednem gibalnem učenju, saj nam omogoča nadgradnjo že usvojenih gibalnih znanj.

Ko gre za poučevanje zahtevnejših gibalnih programov, je demonstracijo smiselno izvajati v treh ravninah: sprednji, stranski in zadnji ravnini, da je učencem pregledno predstavljeno gibanje, ki se ga učijo. 


\section{VREDNOTENJE KOT PODLAGA ZA ZAGOTAVLJANJE KAKOVOSTI V GIBALNEM POUČEVANJU}

Testiranje, merjenje in nasploh vrednotenje gibalnih sposobnosti in/ali gibalne kompetentnosti je lahko pomemben element podpore in predstavlja izhodišče za načrtovanje ter je kazalnik uspešnosti gibalnega poučevanja.

Ocenjevanje, subjektivno in objektivno, je ključno orodje za vrednotenje doseganja pričakovanih izidov učencev kot tudi dela vzgojitelja - ali je dosegel zastavljene cilje ter izpolnil pričakovanja delodajalca ter učenca. Poleg tega je lahko tudi podpora pri učiteljevem osebnem in kariernem poklicnem razvoju.

Dejstvo je, da je od stopnje razvitosti gibalnih sposobnosti odvisna posameznikova izvedba gibov. Gibalne sposobnosti so, tudi to je dokazano dejstvo, $v$ določeni meri prirojene, ene bolj, kot npr. hitrost, druge manj, kot npr. moč. $\mathrm{S}$ testiranjem ugotovimo raven razvitosti gibalne sposobnosti $v$ določenem časovnem obdobju in na tej osnovi lahko učinkovito upravljamo nadaljnji potencialni razvoj gibalnih sposobnosti, saj je samo od posameznika odvisno, kakšne obremenitve so zanj primerne in varne ter mu prinašajo pričakovane koristi.

Pri testiranju običajno uporabljamo baterijo testov kot seštevek primernih testov, s katerimi dosežemo cilj testiranja (Henderson, Sugden in Barnett, 2014). Z njimi lahko odgovorimo na vprašanja:

- Koliko testov?

- Kateri testi?

- Koliko ponovitev?

- Kateri rezultat upoštevati? 
Pri organiziranju vrstnega reda izvajanja testiranja moramo upoštevati še motilce, kot so utrujenost, zunanji šumi in motnje ter obremenjevanje/razbremenjevanje delov telesa.

Navodila za merilce vsebujejo opis merskih testov s sliko in z vsemi navodili, pripravo zapisnikov, motivacijo merjencev, jasna navodila merjencem, primerno preizkušanje in korektno izvedbo testiranja gibalnih sposobnosti. Pogosto se pojavi vprašanje, katero metodologijo testiranja izbrati. Ali kakovostno in kvantitativno ocenjevanje? Zaradi velike povezanosti med kakovostno usvojenim pravilnim gibalnim vzorcem in gibalnim rezultatom je učinkovito vrednotenje lahko le $v$ kombiniranem pristopu ocenjevanja kakovosti (skladnost, mehkobnost, uglašenost gibanja ...) in kvantitativnega merjenja (npr.: dolžina v cm, hitrost v sek....).

Pri testiranju je pomembno upoštevati še načelo nezdružljivost podatkov različnih testov, saj se rezultati med testi ne morejo vedno primerjati, zato je težko ugotavljati razvojne trende testiranega dosežka. Ovrednotenje rezultatov lahko oblikujemo ne samo verodostojno, ampak tudi otrokom prijazno. Tako npr. poleg metra, s katerim natančno merimo dolžino skoka $v$ daljino $z$ mesta $v$ centimetrih, postavimo še trak, ki je razdeljen na petcentimetrske pasove različnih barv ali opremljen z različnimi slikami živali, za katere je značilen skok (žaba, zajec, kenguru ...). Na ta način bo otrok lažje, raje ter dejavneje sodeloval in tudi opisno izmeril dolžino svojega skoka.

Med vrednotenje lahko uvrstimo tudi spodbujanje v obliki pohvale. Z vsako pohvalo otroka vsem otrokom sporočamo, kaj je merilo gibalnega uspeha v vadbeni uri. Posredno namreč ustvarjamo zglede in standarde uspešnosti v skupini, zato moramo imeti oblikovane ustrezne kriterije s kazalniki, ki se vežejo na doseganje ciljev oz. gibalnega napredka otroka. Pri tem se ne opiramo na osebnostne lastnosti otroka (zelo si priden ...), ampak na njegov gibalni napredek (lepo si podal žogo ...).

Testiranje naj bo otrokom prijazno izvedeno in dosežki razumljivi, kot npr. pri skoku v daljino z mesta, ko vzgojitelj meri doseženo dolžino v centimetrih, ampak otrok skače v »kengurujeva« pobarvana polja.

Spremljanje in vrednotenje gibalnih sposobnosti še ni običajna praksa v slovenskih vrtcih, čeprav bi zaradi družbenih sprememb in s tem življenjskega sloga temu morali nameniti več pozornosti. Uporabnost tovrstnih podatkov bi bila velika, saj bi bili podatki uporabni tako na kratki kot na dolgi rok. Kratkoročno bi podatke uporabljali pri spremljanju otrokovega napredka, prilagajanju vsebin vzgojnega procesa potrebam otrok, kot povratno informacijo staršem na pogovornih urah, pri informiranju strokovnih delavcev in vodstva o fizičnem statusu otrok, na podlagi katerih bi bili izvedeni ukrepi za izboljšanje 
ali ohranjanje motoričnih sposobnosti otrok. Upravičenost nakupa potrebnih športnih rekvizitov in pripomočkov bi bila smiselna in racionalna poraba finančnih sredstev. Na dolgi rok bi bili podatki uporabni za medsebojno primerjanje gibalnih sposobnosti med generacijami.

Problem spremljanje in vrednotenje gibalnih sposobnosti mlajših otrok so preučevali že Strel in Šturm (1981), Videmšek in Cemič (1991) ter Rajtmajer (1991), ki so ugotovili, da nekatere merilne značilnosti testov niso stabilne in da otroci pri izvajanju testov naredijo veliko število napak, zato je dosežke smiselno upoštevati $z$ določeno mero zadržanosti.

V predšolskem obdobju so namreč vsa področja otrokovega razvoja tesno povezana, zato se pri testiranju ne smemo osredotočiti samo na pravilno motorično izvedbo gibalne naloge, temveč otroka opazujemo kot celoto: njegovo osebnost, pristop do naloge, čustva, ki jih izkazuje, in motiviranost za izvedbo gibalne naloge. Prav slednje je glavni vzrok, s katerim dosežemo, da otrok doseže svoj optimalni rezultat. Pri nekaterih otrocih podatkov o razvitosti gibalnih sposobnosti ni mogoče pridobiti z veljavnimi testi, saj zaradi svojega nedozorelega gibalnega vedenja (nemirnost, raztresenost, slaba koncentracija, pomanjkanje gibalnih izkušenj ipd.) ne morejo slediti zahtevanim nalogam (Kremžar in Petelin, 2001).

Zaradi kompleksnosti organizacije in izvedbe spremljanja ter vrednotenja gibalnih sposobnosti je smiselno, da ju opravlja oseba, ki je dovolj kompetentna in strokovno usposobljena na področju gibalnega razvoja otrok. Boekaerts (2013) ugotavlja, da morajo učitelji z namenom priprave učinkovitejših učnih okolij razumeti, kako delujejo kognitivni in motivacijski sistemi in kako vplivajo drug na drugega. Učinkovito gibalno učno okolje je spodbudno, izkušenjsko bogato, $v$ njem se otrok počuti varno, sprejeto in lahko pokaže ves svoj potencial. Takšno okolje v vrtcu najlažje ustvarimo, če otroka vključimo v celoten proces načrtovanja in izvajanja gibalnih dejavnosti, v tem primeru testiranja. Otrokov občutek, da soodloča in svobodno usmerja svoja ravnanja, lahko tako otroku kot izvajalcu meritev olajša potek testiranja, zato otrokom omogočimo svobodo pri načinu reševanja gibalnega problema in gibalne izvedbe. 



\section{OPREDELITEV POJMOV POUK IN POUČEVANJE}

Z vzgojo in usposabljanjem na področju gibanja je neločljivo povezan pojem pouk, ki ga preučuje in raziskuje didaktika. Ta je mejna znanost in občutljiva za spremembe $v$ družbi. Veže se na številne druge znanosti in njihove discipline ter svoje usmeritve oblikuje na spoznanjih obče teorije o vzgoji in izobraževanju. Didaktika ne temelji samo na poznavanju pravih strategij, taktik in postopkov poučevanja, ampak predvsem na prepoznavanju pravega zornega kota, s katerim vzgojitelj lahko uspešno obravnava učno snov in učenca.

Poznamo več oblik. Tako pedagoške didaktike preučujejo izobraževalne procese $z$ vidika poučevanja otrok kot discipline, ki ugotavlja učna načela ter preučuje vsebine, oblike, metode, sredstva in organizacijo takega pouka, kar je lahko tudi didaktika športa. Gre za specialne pedagogike, ki se poglobljeno ukvarjajo s posameznimi segmenti poučevanja. Med specialne pedagogike lahko uvrstimo kineziološko pedagogiko, ki preučuje in raziskuje podajanje kinezioloških vsebin otrokom. Sodoben pojem posega na področje prostočasnih aktivnosti otrok, mladostnikov in ga imenujemo pedagogika prostega časa, ki je za delovanje vzgojiteljev izjemnega pomena. Preučuje in raziskuje možnosti vzgoje in izobraževanja otrok ter mladostnikov v prostem času in prestavlja pomemben trg dela vzgojiteljev. Zgodovina pedagogike preučuje zakonitosti razvoja vzgoje otrok in mladostnikov vzporedno z razvojem družbe ter njenimi pojavnimi značilnosti v času in prostoru. Ker je sodoben čas turbulenten in poln neznank, je za vzgojitelja tudi to pomembno področje, saj $s$ preučevanjem zgodovine telesne kulture lažje napovedujemo scenarije razvoja gibanja v prihodnosti. 
Kot pedagoške osnove vzgojitelji obravnavamo celostno podajanje kinezioloških vsebin glede na ciljne skupine in zastavljene namene:

- podajanje gibalnih vsebin otrokom v zgodnjem otroštvu s ciljem razvijanja gibalnih sposobnosti in pridobivanjem gibalnih kompetenc, da bodo gibalno kompetentni (npr. da bodo usvojili elementarne gibalne vzorce (tek, met, skok ...) in gibalne stereotipe (npr.: plavanje, smučanje ...)),

- podajanje znanja kinezioloških vsebin otrokom in mladostnikom s ciljem razvijanja in ohranjanja gibalnih sposobnosti ter pridobivanja in ohranjanja gibalnih kompetenc, da bodo čim bolj gibalno kompetentni in da bodo vzpostavili zdrav življenjski slog.

Sodobna specialna didaktika podajanja kinezioloških vsebin temelji predvsem na:

- preučevanju zakonitosti poučevanja gibalnih vsebin,

- obravnavanju odnosov med učiteljem in učencem,

- podajanju gibalnih nalog, informacij in problemov za izvajanje gibalnih storitev ter s tem razvoj novih gibalnih znanj,

- izbiranju najprimernejših načinov za ustrezen razvoj gibalnih sposobnosti in za učinkovito gibalno učenje, vadbo in rabo gibalnih/športnih storitev, in

- preučevanju najprimernejše učne oblike, metode, vsebine in organizacijske oblike za učinkovito delo z otroki na področju razvoja gibalnih sposobnosti, gibalnega poučevanja in izvajanja gibalnih/športnih dejavnosti. 


\section{DIDAKTIKA KOT MOST MED TEORIJO IN PRAKSO}

Pouk lahko opredelimo kot načrten, sistematičen in postopen proces, ki poteka po preizkušenih učnih oblikah in metodah s ciljem, da s pomočjo učitelja učenca pripeljemo do zastavljenega učnega cilja, do katerega najbrž sam ne bi uspel priti.

V grščini didáskō pomeni učim, poučujem. Didaktiko opredeljujemo kot znanstveno vedo, ki obravnava vsebino, metode in organizacijo pouka. Je nauk o poučevanju. Področje didaktičnega raziskovanja so procesi in zakonitosti načrtovanja, izvajanja in vrednotenja pouka, vsebinski, metodični in organizacijski vidiki vzgojno-izobraževalnega procesa kot tudi izobraževanje izven pouka, ki lahko poteka v procesih formalnega in neformalnega izobraževanja ter poučevanja (Strmčnik, 2001). Specialna didaktika je nauk o poučevanju določenega področja (npr. kinezioloških vsebin), ki preučuje poučevanje s sredstvi kinezioloških vsebin in v prilagojenem okolju. Uporablja specialne metode, sredstva, pripomočke, orodja. Obravnava učne metode, oblike in organizacijske pristope ter metodične poti.

Didaktiko opredeljujeta dve skrajnosti. Zagovorniki celostnega pristopa navajajo, da so za poučevanje neizbežno potrebni intuicija, pedagoški čut in pedagoška praksa, medtem ko teoretiki menijo, da zadošča že znanje teorije. Kot običajno je resnica nekje vmes: refleksija pedagoške prakse s pomočjo pedagoške teorije. 


\section{DIDAKTIČNA NAČELA}

Didaktiko lahko poimenujemo tudi kot teorijo izobraževanja in poučevanja. Ta je več kot samo seštevek učnih tehnologij, infrastrukture in človeških virov. Pri gibalnem učenju učenec išče lastne odgovore na vedno isto vprašanje: kako rešiti gibalni izziv? Pri čemer so načini, s katerimi išče odgovore, lahko različni. Zato so lahko didaktična načela predvsem smernice za učinkovito poučevanje, kot npr.: učimo od lažjega k težjemu, od znanega k neznanemu, od enostavnega k zapletenemu itd., nikakor pa ne navodila za poučevanje.

Ključna didaktična načela so (povzeto po Videmšek in Pišot 2007; Retar, 2017):

Načelo postopnosti in sistematičnosti - vsebine podajamo zlagoma, brez preskakovanja, najprej lažje, potem težje elemente: od lažjega k težjemu, od znanega k neznanemu, od enostavnega k zapletenemu.

Načelo povezovanja teorije s prakso - teorijo povežemo z aktualnimi in realnimi problemi iz vsakdanje prakse, da otrok lažje razume učno snov ter si bolje predstavlja končno gibalno storitev.

Načelo trajnosti znanja - naučiti in usposobiti učeneca, da bo naučene gibalne vzorce pravilno in učinkovito usvojil ter optimalno uporabljal.

Načelo lastne aktivacije - spodbujamo in podajamo dodatne naloge in vaje, da učeneca aktivno vključimo v dejavnost.

Načelo primernosti - vsebina, oblika, organizacija, didaktika so primerno in skladno izbrane glede na gibalne sposobnosti, gibalno predznanje in motivacijo učeneca ter glede na okoliščine in zastavljene cilje.

Načelo nazornosti - učenec nas mora razumeti in svoja pričakovanja uskladiti z našimi.

Načelo primernosti in akceleracije - prilagajanje učencu; pri tem se izbira med akceleracijo ali primernostjo gibalnih vsebin ter ciljev in se nagiba bolj na stran akceleracije.

Načelo individualnosti poudarja individualno izražanje učenca. Učitelj mora ustvarjati možnosti in učenca predvsem spodbujati, da na svojstven način reši gibalni problem in si tako razvija gibalno ustvarjalnost.

Načelo interesa, doživljajev in motivacije upošteva učenčev interes kot njegovo težnjo, da se odzove na izzive in pričakovanja.

Načelo vodenja narekuje vzpostavitev ugodnega učnega okolja, v katerem ni strahu, ampak spodbujanje, vodenje, usmerjanje, pomoč in prilagoditve učencem, da lažje, hitreje in učinkoviteje dosegajo cilje. 
Načelo aktivnosti upošteva potrebo po gibanju, igri, druženju in doživetjih.

Načelo socializacije upošteva, da je učence potrebno ustrezno pripraviti na življenje $v$ družbi in zlasti na športno okolje, jih usposobiti za obvladovanje tako zmage kot poraza, prijateljstva, poštenosti in »fair playa«.

Načelo racionalizacije in gospodarnosti upošteva nabor in organizacijo vsebine, s čimer učinkovito dosegamo zastavljene cilje.

Načelo inovativnosti narekuje izbor novih ali prenovljenih, privlačnih, všečnih vsebin. Temelji na preučevanju rutinskih procesov proizvodnje gibalnega znanja in išče nove izzive na področju ugovarjanja ustaljenim učnim praksam ter ritualom aktualnih izobraževalnih sistemov.

Načelo varnosti in preprečevanja poškodb temelji na izbiri in organizaciji varnih vsebin ter izogibanju tveganj.

\section{Načelo participatornosti in reflektiranja}

Načela se zlasti v povezavi z novimi pedagoškimi dognanji seveda spreminjajo, odvzemajo, dopolnjujejo pri pedagoški praksi. V modernem zgodnjem gibalnem poučevanju se uveljavlja načelo participatornosti ali vključenosti strokovnih delavcev $v$ pedagoški proces. Načelo zagovarja združevanje različnih perspektiv, pogledov in spodbud, ki lahko prispevajo k učinkoviti izmenjavi strokovnih mnenj, pogledov, stališč ter tako h kakovostnemu poučevanju. Razvijanje oblikovalske strategije, ki spodbuja participatornost, naj temelji na iskanju načinov za raziskovanje na področju deljenja različnih perspektiv, taktik in postopkov gibalnega poučevanja. Razmišljanje o problemu in njegovi rešitvi je namreč zastarela strategija. Naivno je presojati, da obstaja samo ena rešitev, postopek, didaktika gibalnega poučevanja, ki je prava in jo je potrebno uveljavljati. Za kakovostno gibalno poučevanje je v izjemno hitro spreminjajoči se družbi ključno prepoznavanje novih izzivov, novih poti, novih postopkov, ki vodijo k naprednemu poučevanju. Zato je pomembno tudi načelo reflektiranja, ki temelji na delitvi lastnega znanja, izkušenj, dobre prakse za skupno dobro v stroki. 



\section{UČNE OBLIKE}

Učne oblike določajo način vodenja učnega procesa $v$ odnosu do učencev in prav tako $v$ veliki meri prispevajo $k$ učinkovitosti poučevanja. Najpogosteje je še vedno uporabljana frontalna oblika, ko učitelj stoji pred otroki in celotni skupini hkrati posreduje informacije, navodila, ji razlaga in demonstrira gibalne strukture ter med ali po izvedbi popravlja ključne napake učencev. Predlagamo, da se pogosteje uporabi skupinska učna metoda, pri kateri vzgojitelj skupini in posamezniku hkrati posreduje informacije, navodila, jim razlaga in demonstrira gibalne strukture ter jih popravlja tako, da k njim izmenično pristopa in se usmerja od skupine do skupine ter k posamezniku in ponovno k skupini. Priporočamo še rabo kombinirane učne oblike, ko združujemo različne učne oblike, predvsem didaktično gibalno igro, poligone in vadbo po igralnih postajah z zgodbo. Seveda pa moramo učne cilje učinkovitega poučevanja prilagoditi glede na objektivne učne okoliščine. Omenjene oblike prispevajo k optimizaciji kompleksnosti in omogočajo povečanje osredotočenosti na posamičnega otroka, manj delitev ter več sodelovanja in prepotrebnega uvida celote (Retar in Lepičnik Vodopivec, 2017).

Med sodobne učne oblike $v$ zgodnjem gibalnem poučevanju uvrščamo naslednje:

Frontalna - učitelj stoji pred skupino učencev in informacije ter navodila podaja celotni skupini hkrati, razlaga ter demonstrira in popravlja.

Individualna - učitelj se $v$ celoti posveti enemu samemu posamezniku.

Delo v parih ali trojkah - učitelj informacije in navodila podaja paru ali trojki hkrati, razlaga ter demonstrira in popravlja tako, da izmenično pristopa in se usmerja od skupine k posamezniku/-kom ter ponovno k skupini. 
Skupinska - učitelj otroke razdeli v več (2-4) skupin (po 3-8 otrok v skupini) in celotni skupini in posamezniku hkrati podaja informacije, navodila, razlaga ter demonstrira in popravlja tako, da izmenično pristopa in se usmerja od skupine do skupine in po potrebi k posamezniku/-kom ter ponovno k skupini.

Didaktična gibalna igra - tehnika poučevanja, ko učitelj zastavlja otroku kompleksna in problemsko zastavljene gibalne naloge $s$ katerimi omogoča ustrezen razvoj vseh dimenzij psihosomatskega statusa.

Krožna vadba - otroci so razdeljeni v več manjših (od 3 do 5) skupin (od 3 do 6 otrok v skupini) in izvajajo gibalne naloge na posamezni postaji skladno $z$ določenim časom trajanja vadbe (od 2 do 5 minut). Potem se skupine zamenjajo na postajah, dokler niso bili vsi na vsaki postaji vsaj enkrat.

Poligon - vzgojitelj oblikuje, običajno v krožni obliki, strukturirane gibalne naloge skladno z zastavljenimi cilji. Otroci izvajajo naloge tekoče drug za drugim (od 3- do 6-krat ponovijo cel krog).

Gibalna vadba po igralnih postajah, kjer je značilno, da na postajah prevladuje igralna oblika ponavljanja izbranih gibalnih dejavnosti, ki razvijajo gibalne sposobnosti in gibalne vzorce.

Prilagojena obhodna vadba z zgodbo, kjer se vsebine prepletajo z zgodbo, s katero otroci osmislijo svoje gibanje.

Štafetne igre - otroci so razdeljeni v več manjših (od 3 do 5) skupin (od 3 do 6 otrok $v$ skupini) in izvajajo gibalne naloge, ki imajo $v$ ospredju nalogo prenašanja izbranega rekvizita $v$ obliki tekmovanja, kjer ne razvrščamo zmagovalcev.

Elementarne igre - gibalne/športne igre s prilagojenimi pravili, ki so lahko tekmovalne, vendar vse do dvanajstega leta brez razvrščanja.

Kombinirana - združuje različne učne oblike s ciljem učinkovitega poučevanja glede na objektivne okoliščine poučevanja in subjektivne okoliščine učencev. 


\section{UČNE METODE}

H kakovosti v poučevanju lahko precej prispevajo primerno izbrane in izvedene učne metode, ki so načini učinkovitega poučevanja, kot npr. analitična, sintetična, celostna, kombinirana, igralna, tekmovalna itd. metoda; to so temeljni načini dela, ki zagotavljajo učinkovito uresničevanje posamičnih etap učnega procesa, učne oblike pa določajo način vodenja učnega procesa v odnosu do učencev. Praviloma se $v$ praksi uporablja učna analitična metoda, ko vzgojitelj podaja snov po korakih. Snov razstavi na dele, razlaga in demonstrira od elementa do elementa ter tako zgradi končno gibalno storitev. Predlagamo rabo kombinirane učne metode, ko vzgojitelj izbere najustreznejše učne metode $v$ učinkovitem zaporedju in jim doda še igralno/tekmovalno metodo, kjer s simulacijo tekmovanja vzpostavimo prijazno tekmovalno okolje, v katerem otroci hitreje dosegajo zastavljene učne cilje. S tovrstnim postopkom prožnejšega uvajanja različnih učnih taktik lahko zmanjšamo količine podatkov in omogočamo poglabljanje uvida $v$ učno snov ter tako optimiziramo učni proces. Učne metode so torej načini dela, ki zagotavljajo učinkovito uresničevanje posamičnih faz učnega procesa. $V$ nadaljevanju predstavljamo izbrane učne metode, ki lahko prispevajo k kakovostnemu uresničevanju učnega procesa:

- analitična metoda - vzgojitelj podaja snov po korakih, snov razstavi na dele in razlaga ter demonstrira od elementa do elementa ter tako zgradi končno gibalno storitev; 
- sintetična metoda - vzgojitelj snov podaja tako, da jo postopoma gradi v celoto;

- celostna metoda kjer vzgojitelj podaja snov $v$ celoti in jo predstavi kot končno storitev, učenec pa jo ponovi;

- kombinirana - vzgojitelj izbere najustreznejše učne metode $v$ učinkovitem zaporedju;

- situacijska - vzgojitelj se odloči za konkretno gibalno storitev - situacijo, s pomočjo katere učence uči;

- igralna - vzgojitelj omogoči igro, s katero učenci razvijajo gibalne sposobnosti in usvajajo zlasti elementarne ter enostavne oblike gibanja;

- tekmovalna - s simulacijo tekmovanja vzpostavimo otrokom prijazno tekmovalno okolje, $v$ katerem dosegajo zastavljene cilje; otroci sicer tekmujejo, ampak jih ne razvrščamo po doseženih mestih oz. rezultatih. 


\section{KRITERIJI ETIČNEGA ZGODNJEGA GIBALNEGA POUČEVANJA}

Temeljna naloga vzgojitelja je vedno in povsod zaščititi otroka. Pri gibalnem poučevanju nam je lahko $v$ podporo nekaj pomembnih kriterijev, s katerimi si lahko pomagamo pri presoji etičnosti našega dela. Morda je najpomembnejši kriterij neškodljivosti, s katerim označujemo, da mora biti naša dejavnost pred oz. z otrokom na prvem mestu neškodljiva. Sledi kriterij dobronamernosti ali koristi, ki jih otrok pridobi z našimi učnimi intervencijami. Kriterij pravičnosti nas usmerja, da ravnamo $z$ vsemi otroki enako pravično, kriterij otrokove avtonomije pa, da otrok soglaša z izvajanjem konkretne gibalne naloge. Pomemben je še kriterij zagotavljanja varnosti in varovanja osebnih podatkov, ki izvirajo iz ocenjevanja, testiranja, merjenja otroka. 



\section{STRUKTURA UČNE ENOTE GIBALNEGA POUČEVANJA}

Učni proces je zavestna in načrtna dejavnost tako učiteljev kot učencev, usmerjena k doseganju vzgojno-izobraževalnih ciljev.

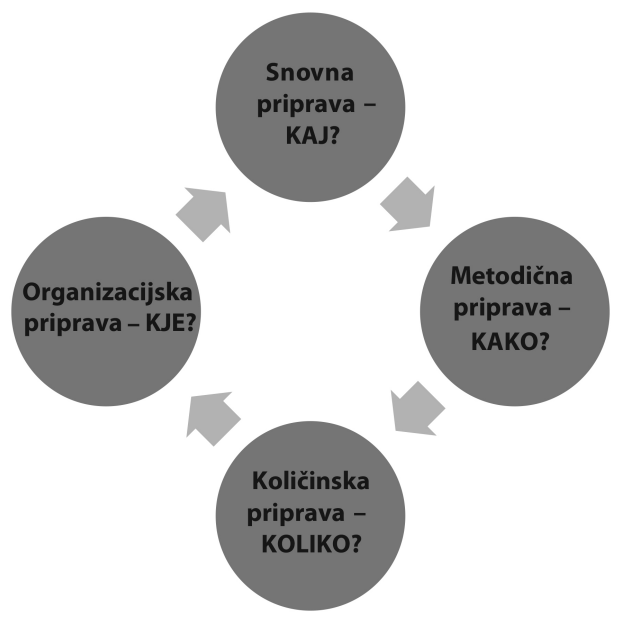

Slika 1: Struktura učne enote gibalnega poučevanja

Kurikulum je učni načrt, sprejet na ravni države, $v$ katerem so opredeljeni cilji praktične in teoretične vsebine, standardi znanja na posamezni stopnji. Učna priprava je vzgojiteljeva dokumentacija priprave na pouk, opredeljena po času, v katerem naj bi se uresničili cilji učnega procesa: gre za letno načr- 
tovanje (zaporedje tem, predvideno število ur, opredelitev aktivnosti, vsebin, načrtovanje časa za preverjanje in ocenjevanje, varnost, ...), srednjeročne (tematsko načrtovanje) in kratkoročne načrte (sprotno načrtovanje - priprava na pouk).

Priprava na pouk ( $v$ tem delu načrtovanja želi vzgojitelj s pomočjo posameznih vadbenih ur in znotraj njih izbranih vsebin, metod in sredstev doseči vzgojno-izobraževalne cilje ali standarde znanj, ki so opredeljeni v učnem načrtu - kurikulu). Pripravi sledijo izvedba, nadzorovanje, evalvacija, ocenjevanje, testiranje...

Na področju inoviranja konceptov učnih praks se vedno pojavljajo novosti, ki lahko prispevajo k izboljšanju učnih izkušenj. Tako se npr. pojavlja pristop »unschooling «, ki zagovarja, da ne slediš strukturi učnega načrta, ampak se prilagodiš zanimanju, izkazanim interesom, talentom in razvojnemu tempu otroka. Menim, da je v primeru, ko vzgojitelj zna in zmore uskladiti in preplesti oba koncepta, mogoče pričakovati kakovostnejši gibalni razvoj otroka, kot če uporabljamo samo en koncept.

\section{SMERNICE ZA OBLIKOVANJE STRUKTURE UČNE ENOTE:}

- Motivacijski del,

- uvodni del,

- glavni del,

- zaključni del,

- logistična podpora in

- evalvacija učne ure. 


\section{SNOVNA IN ORGANIZACIJSKA PRIPRAVA}

Snovna priprava vsebuje teoretična izhodišča, na podlagi katerih bomo izvajali učni proces in ga osmislili glede ciljev ter ključnih pristopov. Organizacijska priprava pa vsebuje praktične okvire procesa za optimalno izvedbo načrtovanega programa kinezioloških ukrepov. $Z$ določanjem učnih strategij, taktik in tehnik, metodik, organizacijskih oblik, pripomočkov, orodja ter organizacije prostora in časa (razporeditev obremenitve in počitka) oblikujemo učinkovito organizacijsko pripravo, ki bo učencem prijazna in bo uresničevala zastavljene splošne ter specialne cilje.

Smernice za oblikovanje pisne priprave učne enote:

- glavni cilji učne enote,

- tip učne enote po vsebini in po fazi učnega procesa (posredovanje novih informacij, ponavljanje, utrjevanje, tekmovanje, preverjanje ...),

- metodične enote glavnega dela,

- posredni cilji: izobraževalni, razvedrilni, vzgojni, zdravstveni, rehabilitacijski ...,

- učne metode,

- učne oblike,

- organizacijske metode,

- organizacijske oblike,

- logistična podpora (videoanaliza, prehrana in hidracija, relaksacija ...) in

- pripomočki ter mediji. 
Pripomočki, orodja, rekviziti in drugi mediji so ključnega pomena za kakovostno poučevanje. Izbor učnih pripomočkov je odvisen od številnih dejavnikov, kot so npr.: starost oz. razvojna stopnja, gibalno predznanje, vzdušje, počutje, motivacija. Pomembni sta tudi faza učnega procesa (učenje, ponavljanje, urjenje, tekmovanje. ..) in faza vadbene enote (uvodni, glavni ali zaključni del). Upoštevati je potrebno še izbrane vsebine, prostorske možnosti in razpoložljivost sredstev. Pomembna je tudi uravnoteženost med sprostilnimi gibalnimi vsebinami (energijska komponenta gibanja) in vsebinami, pri katerih se učenec posveča gibalnemu učenju (informacijska komponenta gibanja). 


\section{IGRA KOT SREDSTVO ZGODNJEGA GIBALNEGA POUČEVANJA}

Igra je prvinski način komuniciranja in družbeno zaželjenega prilagajanja otroka družbi odraslih, ki budi notranje potenciale otrok s pomočjo čutnih, gibalnih, socialnih in spoznavnih izkušenj v realnem času.

Razvojni psihologi (Vigotski) poudarjajo svobodo kot pomemben dejavnik pri otrokovem razvoju. V okolju, v katerem prevladuje svoboda in je vzgojiteljeva vloga nudenje pomoči, ko jo otrok potrebuje, se otrok hitreje uči in razvija zlasti na področjih, ki so zanj ugodna, ter si s tem razvija in zgradi samozavest ter samospoštovanje, kar je za njegov kasnejši razvoj zelo pomembno. Zato je igra, v kateri prevladuje svobodna izbira, tako zelo pomembna.

Otrokov razvoj (Marjanovič Umek in Zupančič, 2005; Pišot in Jelovčan, 2006; Gallahue idr. 2011) poteka na področjih, ki se med seboj dopolnjujejo, pogojujejo in prepletajo ter se lahko prepoznavno izrazi tudi v igri. To so kognitivni razvoj (razvoj občutenja in zaznavanja, razvoj govora, spoznavanje in raziskovanje okolja, reševanje problemov), razvoj domišljije in ustvarjalnosti, razvoj socialne kognicije, emocionalni razvoj (sproščanje in izživljanje čustev, npr. doživljanje zadovoljstva, premagovanje strahu, premagovanje težav in konfliktov, uresničevanje želja ...), socialni in moralni razvoj (razvoj socialne kompetentnosti (sodelovanje, razumevanje in upoštevanje drugih), razvoj samokontrole (npr. impulzivnosti, agresivnosti), osvajanje družbenih pravil in norm), osebnostni razvoj (razvoj avtonomnosti, spoznavanje sebe (oblikovanje samopodobe) in sveta (spoznavanje različnih vlog in vstopanje v svet odraslih)) in nenazadnje razvoj gibalnih spretnosti ter sposobnosti, ki je za naš predmet seveda ključnega pomena. 
Ločimo več formatov otroške igre: razvedrilnega, tekmovalnega, didaktičnega, športnega ali kombiniranega.

Igra v vsakem otroku predstavlja ustvarjalni potencial, ki se nikoli ne razvije, če ga ne spodbujamo ali celo zaviramo, misleč, da je igra odvečna dejavnost.

$\checkmark$ vrtcih pogosto uporabljamo različne gibalne igre, pri katerih so vključeni vsi otroci, tudi zato, da jim pomagamo pri razvoju in vključitvi v skupino. Delimo jih lahko na:

- elementarne igre - igre, ki vključujejo elementarne oblike gibanja in v katerih imamo možnost prilagajanja pravil trenutni situaciji in potrebam; so nadgradnja naravnih oblik gibanja (lovljenje, skrivanje, rajanje);

- rajalne igre - preproste plesne oblike, pri katerih se udeleženci gibljejo po ritmu pesmi, ki jo praviloma tudi pojejo;

- igre ponazarjanja - igre, pri katerih otrok ponazarja predmete, oponaša živali in predstavlja pojme;

- socialne igre - igre, $s$ katerimi podpiramo socialne veščine, čustva posameznika in vedenjske spretnosti, ki so pomembne za kakovostne medosebne odnose (komuniciranje, sklepanje prijateljstev, spoznavanje, kaj je prav in kaj ne ...).

Značilnosti igre povzemamo po M. Videmšek in N. Jovan (2002):

- Ni toliko sredstvo treninga za življenje kot sredstvo za razvedrilo ter ohranjanje zdravja in delovnih sposobnosti;

- ima tudi uporabno vrednost, kot sredstvo vzgoje in poučevanja, vendar ne več za preživetje, temveč za kvalitetnejše življenje;

- ima pomembno vlogo pri razvoju otroka v celostno, harmonično in ustvarjalno osebnost;

- $\quad$ z igro otrok razvija svoje telesne sposobnosti in duševne razsežnosti, zadovoljuje potrebo po gibanju, hkrati pa je igra pomembna tudi za socializacijo, saj otroka postopno navaja na življenje v skupnosti;

- je svobodno izbrana psihofizična dejavnost, pri kateri poteka ne moremo predvideti vnaprej;

- je dejavnost, ki se uresničuje $v$ mejah, določenih glede na čas, prostor ter pravila. 


\section{NESTRUKTURIRANA GIBALNA IGRA}

Organizirana, strukturirana gibalna igra temelji na načrtni postavitvi gibalnih in drugih ciljev, ki naj bi jih otroci dosegali z uporabo igre. Vaditelj otroke opazuje in usmerja, da se približujejo in dosegajo pričakovane gibalne dosežke. Običajno se otroci zavedajo, da so opazovani in poskušajo igrati vloge, ki jim jih vzgojitelj narekuje, zato nastopajo in niso povsem iskreni. Razlika med strukturirano in nestrukturirano gibalno igro je $v$ tem, da pri slednji otroci uporabljajo gibanje, ki nima opredeljenega cilja, in je cilj igra sama po sebi. Tovrstna igra lahko učinkoviteje spodbuja ustvarjalnost pri otroku tudi na področju prepoznavanja specifičnih rešitev gibalnih problemov ter prispeva k raznolikemu gibalnemu obnašanju posameznika in predstavlja mehak prehod v organizirano športno vzgojo - celostni sistem gibalnega poučevanja in poučevanja s ciljem gibalnega ter osebnostnega razvoja človeka v kasnejšem obveznem osnovnošolskem izobraževanju.

\section{DIDAKTIČNA GIBALNA IGRA}

Didaktična gibalna igra predstavlja celostno tehniko gibalnega poučevanja, ki deluje na otroka in mu z množico kompleksnih in problemsko zastavljenih gibalnih nalog omogoča ustrezen razvoj vseh dimenzij psihosomatskega statusa.

Njena temeljna značilnost pa je $v$ tem, da svoje specifične karakteristike išče $v$ razvojnih posebnostih otroka in otroku samem, ker iz njega izhaja. Zato naj bo otrokov cilj v igri vodilo vzgojitelju (Pišot, 2007).

$\checkmark$ vsakem obdobju otroštva ima igra nekoliko drugačno vlogo in pomen oz. smisel. Število igrač v prvih treh letih otroštva naglo narašča, nato pa začne upadati in otrok se lahko igra dlje časa z manj igračami, ki zanj postajajo bolj zanimive - tudi gibalne/športne aktivnosti. Prav tako se poveča zanimanje za interakcijo z vrstniki, zato je pomembno vključevanje iger, v katerih otroci spoznavajo in razvijajo stike $z$ vrstniki. 


\section{ELEMENTARNE IGRE}

V primerjavi z gibalnimi didaktičnimi igrami in športnimi igrami, kot so odbojka, košarka, tenis ipd., imajo elementarne igre preprosta in prilagodljiva navodila (glede na cilje in sposobnosti otrok), medtem ko imajo športne igre natančno določena pravila, ki jih ne smemo spreminjati, cilj igre pa je zmaga. Pri elementarnih igrah pa je zmaga le motivacijsko sredstvo za dosego izbranega cilja. Pri športnih igrah morajo biti za izvedbo igre gibalne kvalitete že razvite na ustreznem nivoju, medtem ko se pri elementarnih igrah skozi igro razvijajo in dopolnjujejo gibalne kvalitete (Pistotnik, 2011). Primer didaktične elementarne igre je lahko igra »Prijatelj, reši me!«, pri kateri so pravila preprosta, niso točno določena, lahko jih spreminjamo ter prilagajamo potrebam otrok (Pistotnik, 2004).

Igra in gibalna/športna dejavnost ter didaktična gibalna igra

Igra je svobodno izbrana dejavnost, pri kateri poteka ne moremo vnaprej predvideti in se uresničuje glede na čas, prostor in pravila.

Igra otroku predstavlja dejavnost, ki je prilagojena njegovim sposobnostim in stopnji dojemanja. Nanj vpliva celostno - pomaga mu pri razvoju na več področjih (gibalnem, socialnem, čustvenem), pri socializaciji, predvsem pa je dejavnost, ki ga pripravlja na vsakdanje življenje (Pistotnik, 2004). Nemec in Krajnc (2011) igro predstavita kot dejavnost, ki je sama po sebi pomembnejša od svojega cilja. Otroku igra pomeni svobodno, spontano dejavnost, za katero je največkrat notranje motiviran. Igra predstavlja namerno dejavnost, ki je usmerjena na predmet in nima posledic. Otrok je zanjo notranje motiviran, pri njej pa mu pomaga njegova domišljija. Nemec in Krajnc (2011) ločita med igrami s pravili in konstrukcijsko igro, ki se pojavi ob koncu prvega leta starosti starejši otroci jo uporabljajo pogosto, saj je povezana z intelektualnim razvojem in s koordinacijo oko - roka, z natančnostjo, vztrajnostjo, ustvarjalnostjo, s poznavanjem in razumevanjem prostorskih odnosov. Igre s pravili pa se pojavijo med drugim in tretjim letom. Takrat se otrok nauči upoštevati pravila, jih razume in se jim prilagodi oz. podredi.

V kulturi, v katero sodi tudi šport, se igre lahko pojavljajo kot samostojne športne panoge, ki imajo vedno točno določena (mednarodno veljavna) pravila - to so športne igre. Pri gibalnih/športnih dejavnostih otrok pa se igre pogosto uporabljajo tudi kot glavno ali pomožno sredstvo za uresničitev različnih ciljev v posameznih delih vadbene enote, za povečanje učinkovitosti gibalnega poučevanja ali pa za številne druge cilje, ki jih uresničujemo na področju vzgoje in izobraževanja. Te igre imenujemo elementarne. Igra je naraven način pri- 
lagajanja otroka družbi odraslih, ki budi notranje potenciale otrok s pomočjo čutnih in lokomotornih izkušenj. Je praviloma svobodno izbrana psihofizična dejavnost, pri kateri poteka ne moremo predvideti vnaprej. Je dejavnost, ki se uresničuje $v$ mejah, določenih glede na čas, prostor in pravila. Motivacija v igri je dosežena z zadovoljstvom samoizražanja in s prijetnostjo, ki jo nudi udeležba v njej, saj premagovanje vedno novih, navideznih preprek omogoča spontano in ustvarjalno potrjevanje lastne osebnosti, ki lahko krepi samopodobo in samozavest otroka.

Elementarne igre lahko razložimo kot obliko iger, ki vključujejo predvsem naravne oblike gibanj in $v$ katerih imamo možnost prilagajanja pravil (bolje, navodil) skladno z zastavljenimi učnimi izzivi. Pistotnik (2011) elementarne igre opredeli kot igre s pravili, prav tako preproste in prilagodljive ciljem, sposobnosti in znanju, biti morajo zabavne in imeti možnost za tekmovalnost, ker $s$ tem ohranjajo motivacijo za gibanje. Pravila lahko spreminjamo glede na gibalno predznanje, starost, razvitost gibalnih sposobnosti, prostor ter število otrok in glede na druge pomembne zunanje dejavnike. Z njimi razvijamo gibalne sposobnosti in spoznavamo različne gibalne informacije. So zlasti skupinske igre, pri katerih je v ospredju gibalna zgodba, domišljijska igra z ohlapnimi pravili, ki se lahko sproti spreminjajo, da otroci ne izgubijo zanimanje zanjo.

\section{CILJI ELEMENTARNIH IGER}

Elementarnih iger ne uvajamo zaradi same igre in zabave, temveč zaradi doseganja različnih ciljev. V pripravljalnem delu vadbe se poslužujemo iger, ki so živahne, saj moramo otroke pripraviti na glavni del vadbe, kjer dobijo nova znanja, utrjujejo obstoječa, razvijajo gibalne in funkcionalne sposobnosti, sodelujejo v skupini, upoštevajo pravila. $V$ sklepnem delu vadbe igre uporabimo za telesno in duševno umirjanje (Videmšek, Strah in Stančevič, 2001). Umeščanje tekmovalnosti v igre omogoča spoznavanje obvladovanja tako zmage kot poraza in predstavlja mehak prehod $v$ športne igre in tekmovalnost $v$ družbi. Zmagovanje lahko, ni pa nujno, za otroke pomeni tudi motivacijo, pri čemer dosežejo cilj in razvijajo gibalne sposobnosti v vseh vadbenih enotah (Pistotnik, 2011). Vsekakor pa razvrščanje po mestih in izrazito poudarjanje tako zmage kot poraza nista priporočljiva vse do dvanajstega leta starosti.

Ključni cilji elementarnih iger (Videmšek in Jovan, 2002): 
- $\quad$ spoznavanje vsebin in pravil preprostih elementarnih iger;

- razvijanje občutka za sodelovanje v skupini;

- pridobivanje občutka za medsebojno pomoč;

- razvijanje vztrajnosti, odločnosti in borbenosti;

- usvajanje osnovnih načinov gibanj z žogo;

- razvijanje koordinacije gibanja celega telesa;

- razvijanje natančnosti in moči;

- vplivanje na srčno-žilni in dihalni sistem ter gibalni aparat.

Vsem avtorjem je pri opredelitvi elementarnih iger skupno to, da so to igre, kjer so vključene naravne oblike gibanja, kot so hoja, tek, lazenje, plezanje, skoki, meti itd., in kjer imajo igre preprosta pravila, zato so značilna hitro razumljiva in preprosta gibanja z možnostjo prilagajanja tako potrebam kot okoliščinam.

\section{DELITEV ELEMENTARNIH IGER}

Pistotnik (2004) je elementarne igre razdelil med elementarne igre v pripravljalnem, glavnem in zaključnem delu vadbe, elementarne igre na snegu, ob vodi, v vodi in pod vodo ter družabne igre in potegavščine. Namen pripravljalnega dela se je ogreti in vzbuditi zanimanje otrok za glavni del vadbe pa tudi za doseganje ciljev; za to so primerna lovljenja, skupinski teki z izmenjavo mest in tekalne igre. $V$ glavnem delu vadbe elementarne igre uporabljamo za razvoj gibalnih sposobnosti, pridobivanje in utrjevanje gibalnih spretnosti in znanj. Izbira igre je pomembna, saj moramo vedeti, kaj želimo z njo doseči in na kaj hočemo vplivati, da bi dosegli cilje, ki smo si jih zastavili. Pri tem uporabljamo štafetne igre, kjer večje število skupin med seboj tekmuje (v tem, kdo hitreje in boljše opravi nalogo). Štafetne igre omogočajo razvoj moči, hitrosti, koordinacije. V glavnem delu vadbe lahko uporabljamo tudi moštvene in borilne igre. Z moštvenimi igrami razvijamo sodelovanje ekipe, z borilnimi pa vplivamo na razvoj moči in gibalnih sposobnosti, kot so hitrost, koordinacija, gibljivost, inteligenca. Elementarne igre v zaključnem delu vadbe vplivajo na telesno in duševno umiritev vadečih. Pri tem uporabljamo predvsem manj obremenilne igre za ravnotežje, natančnost, orientacijo v prostoru in hitro odzivnost. Pri elementarnih igrah na snegu otroke najprej ogrejemo z živahnimi igrami in jih s tem privajamo na tehniko gibanja ter gibanje $z$ opremo. $Z$ 
igrami ob vodi, $v$ vodi in pod vodo otroka pripravimo na to, da se brez strahu privadi na vodo.

Elementarne igre lahko opredelimo kot športne igre, ki jih lahko $v$ gibalni dejavnosti uporabljamo kot glavno ali pomožno sredstvo za dosego ciljev $v$ uvodnem, glavnem in zaključnem delu vadbe. Ogrevanje z elementarnimi igrami $v$ uvodnem delu vadečim omogoča hkratno aktivno sodelovanje, kjer se izbere dinamična igra, ki vpliva na krvožilni in dihalni aparat ter na usklajeno gibanje mišičnih skupin. Pravila igre so enostavna, tako da jih otroci hitro razumejo. Struktura igre je preprosta, lahko temelji na zgodbah, ki z vključevanjem domišljijskega sveta otrokom približa učne cilje. Še posebej priporočamo t. i. gibalno zgodbo, ki jo lahko pojmujemo kot domišljijsko zasnovano besedno sporočilo vzgojitelja, s katerim otrokom osmisli gibanje, gibalne naloge in gibalne probleme, da jih lažje, raje in učinkoviteje rešujejo v okviru zgodbe, ampak na svojevrsten način.

Igra lahko postane intenzivnejša in povezana z glavnim delom vadbene enote, ki vpliva na razvoj gibalnih sposobnosti. V zaključnem delu vadbe elementarne igre omogočajo razvoj natančnosti (s ciljanjem v tarčo), ravnotežja, prostorske orientacije in hitre odzivnosti (z manjšo dinamiko gibanja).

Elementarne igre lahko delimo po vsebini in obliki. Po obliki so lahko intenzivne ali umirjene. Intenzivne uporabljamo v pripravljalnem delu vadbe, kjer otroke telesno in psihično pripravimo oz. ogrejemo za glavni del. Umirjene igre izberemo $v$ zaključnem oz. sklepnem delu, kjer otrokom omogočimo umirjanje, pri čemer pa ni nujen naveden vrstni red. Bistveni kriterij, kdaj bo na vrsti katera oblika, je namreč usklajenost med informacijsko in energijsko komponento vadbene enote. $V$ primeru, ko smo v prvem delu poudarek namenili čuječnosti, umirjenosti, zbranosti, bomo $v$ drugem delu postavili $\checkmark$ ospredje intenzivne, igrive oblike. M. Videmšek in M. Visinski (2011) sta elementarne igre sicer razdelili glede na dve starostni skupini: izvajanje v prvi starostni skupini (od prvega do tretjega leta) poteka tako, da se otroci lovijo, skrivajo, rajajo z uporabo pripomočkov ali brez njih, v drugi starostni skupini (od tretjega do šestega leta) pa se otroci lovijo, tečejo skupinsko z menjavo mest, igrajo štafetne igre, igre ravnotežja, natančnosti, hitre odzivnosti, in sicer brez uporabe pripomočkov ali z njimi. Tovrstni kriterij je priročen, zmanjšuje pa avtonomnost vzgojitelja, da oceni, kdaj je kakšna vsebina ali oblika za otroke najprimernejša.

Naloge elementarnih iger $v$ vadbeni enoti so lahko podpora za: 
- ogrevanje ( $v$ uvodnem delu vadbene enote);

- razvoj gibalnih sposobnosti (v glavnem delu vadbene enote);

- pridobivanje in utrjevanje gibalnih informacij ( $v$ glavnem delu vadbene enote);

- umirjanje ( $v$ zaključnem ali začetnem delu - odvisno od obremenitev vadbene enote).

\section{Ogrevanje}

Elementarne igre, namenjene ogrevanju, naj izpolnjujejo naslednje kriterije:

- vsi vadeči morajo imeti možnost hkratnega aktivnega sodelovanja v igri;

- igre morajo vsebovati živahno motoriko (morajo biti dinamične);

- zaradi dejavnosti mora priti do usklajenega delovanja velikih funkcionalnih sistemov (dihalnega, krvožilnega) in do uskladitve delovanja mišičnih skupin;

- pravila iger naj bodo preprosta, da jih vadeči hitro dojamejo in se igra lahko čim prej razmahne v vsej svoji dinamiki;

- priporočljivo je, da ima igra gibalno povezavo z glavnim delom vadbene enote (vsebinsko in gibalno).

- Primeri elementarnih iger med ogrevanjem:

- lovljenje (beg pred lovcem);

- skupinski teki z izmenjavo mest (tekmovanja skupin $v$ hitri in pravilni izvedbi zadanih gibalnih nalog);

- tekalne igre (med gibanjem po prostoru hitre in pravilne reakcije posameznikov na dana povelja).

\section{Elementarne igre $\mathbf{v}$ glavnem delu vadbene enote}

Gibalne sposobnosti, na katere se lahko $z$ elementarnimi igrami vpliva $v$ glavnem delu vadbene enote, so: moč, hitrost, nekatere pojavne oblike koordinacije pa tudi natančnost in ravnotežje. Na razvoj gibljivosti se z elementarnimi igrami v večji meri ne da vplivati, lahko pa se z ustreznim izborom gibanj (nekatera plazenja in plezanja) vpliva na njeno ohranjanje.

\section{Elementarne igre za razvoj gibalnih sposobnosti}

Uporabljamo lahko štafetne igre, s katerimi se lahko vpliva predvsem na razvoj moči, hitrosti in koordinacije ter se $z$ njimi utrjujejo gibalne informacije. Primerne so tudi izbrane skupinske ali ekipne igre, s katerimi se spodbudi vključitev celotnega spleta gibalnih sposobnosti, pri čemer se s pravili poudari pomembnost izbrane sposobnosti (krepitev iztegovalk rok, natančnost za- 
devanja koša ipd.), ali pa se ob njihovem aktiviranju omogoči usvojitev izbranih gibalnih znanj in prilagojenih oblik borilne igre, pri katerih je poudarjena predvsem moč.

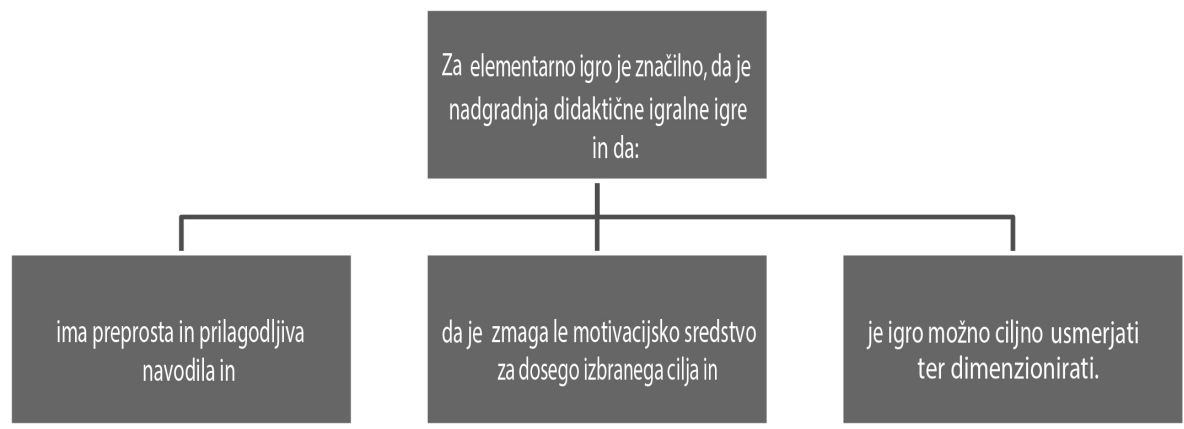

Slika 2: Značilnosti elementarne gibalne igre

\section{Zaključni del vadbene enote}

$\mathrm{Na}$ koncu vadbene enote naj bo dinamika gibanja majhna. $V$ gibanje naj se ne vključuje predinamično velikih mišičnih skupin, dihalni in krvožilni sistem naj ne bosta preveč obremenjena. Igre naj otroke sprostijo. V kolikor intenzivnost $\mathrm{v}$ glavnem delu ni bila dosežena, pa je smiselno $\mathrm{v}$ zaključnem delu povečati obremenitve.

\section{Elementarne igre $\mathbf{v}$ zaključnem delu}

Izbiramo lahko med igrami, ki vsebujejo elemente natančnosti (zadevanje tarč na predpisan način), ravnotežja (predvsem ohranjanje ravnotežnega položaja), orientacije v prostoru (vadba kinestetičnega občutka - občutek za položaj lastnega telesa $v$ prostoru ob izključitvi čutila vida) in hitre odzivnosti (hitre reakcije $z$ manjšimi telesnimi segmenti, ki niso energijsko zahtevne).

\section{Priporočila za kakovostno izbiro in izvedbo elementarnih iger}

- spoštovanje načela postopnosti;

- pomen opazovanja otrok in njihovih odzivov ter pomen poznavanja otrok;

- prilagajanje zahtevam otrok in izpolnjevanje njihovih pričakovanj;

- skrbna izbira vsebine in oblike iger glede na gibalno zahtevnost izvedbe ter gibalno-razvojno stopnjo otrok. 


\section{NAČELA POSTOPNE OBREMENITVE PRI IGRAH}

- Ustrezna izbira igre glede na pogoje in cilje - igre se lahko razlikujejo glede zahtevnosti gibanja ali glede intelektualnih zahtev;

- $\quad$ spreminjanje igralne površine - igra postane zahtevnejša ali lažja, če se realizira na različnih podlagah, ker se s tem spremenijo gibalne zahteve (asfalt, trava, parket, voda, sneg ipd.);

- spreminjanje velikosti igrišča - spreminja se dinamika gibanja in s tem tudi obremenitev (manjše igrišče - krajše razdalje, večje igrišče - daljše razdalje);

- $\quad$ spreminjanje števila igralcev - vpliva na večjo ali manjšo dinamiko gibanja (npr. večje število lovcev);

- spreminjanje igralne motorike - povečanje obremenitve izbranih segmentov (za postopno obremenjevanje nog - tek, sonožni poskoki, enonožni poskoki) ali vpliv na druge segmente (npr. sonožni poskoki - večja obremenitev nog, zajčji poskoki - večja obremenitev rok);

- $\quad$ spreminjanje trajanja igre oz. števila ponavljanj igre - daljše trajanje ali večje število ponovitev pomeni večjo obremenitev vadečih.

\section{Priporočila za kakovostno zasnovano in izvedeno gibalno igro}

- Spoštovanje načela postopnosti;

- pomen opazovanja otrok, njihovih odzivov, pomen poznavanja otrok;

- prilagajanje zahtevam - razvojni stopnji otrok;

- pazljiva izbira iger glede na gibalno težavnost;

- motivacija zanjo je dosežena z zadovoljstvom samoizražanja in s prijetnostjo, ki jo nudi udeležba v njej, saj premagovanje vedno novih navideznih preprek omogoča spontano in ustvarjalno potrjevanje lastne osebnosti, ki lahko krepi samopodobo in samozavest otroka;

- zagotavljanje svobodnih izbir rešitev gibalnih problemov, zaradi česar bodo otroci bolj prepričani o svojih gibalnih spretnostih, saj so jih pridobili na svoj način;

- svobodno izbiranje rešitev socialnih problemov zlasti na področju vzpostavljanja in vzdrževanja dobrih in enakopravnih odnosov ter sodelovanja pri udeležencih igre - sicer bo skupne igre kmalu konec. 


\section{ZAGOTAVLJANJE VARNOSTI PRI GIBALNEM POUČEVANJU}

Kdaj se pripeti športna nesreča?

Zavedanje gibanja vsebuje zaznavanje, razumevanje in predvidevanje dogajanja $v$ povezavi $s$ telesom in prostorom $v$ realnem času. Ko se torej učenčeva pričakovanja nepričakovano ne uresničijo in ga novi dogodki presenetijo, se zgodi nesreča.

Odklon zaznav in pričakovanj od stvarnosti najpogosteje privede do težav in, če je splet okoliščin neugoden, tudi do športne nesreče.

Pojem »nepozornostna slepota opisuje, da tistega, na kar nismo pozorni, ne bomo videli. Prav tako smo lahko »slepi« za spremembe, ker smo vajeni rutine. Zato je ključna vzgojiteljeva vloga, da otroke usmerja k predvidevanju in zlasti usmerjanju pozornosti na za gibanje ključne dražljaje. 



\section{KOMPLEKSNO RAZUMEVANJE DRAŽLJAJEV IZ OKOLJA}

Predelava informacij »od zgoraj navzdol« obsega vplive izkušenj, pričakovanj, motivacije, ki vplivajo na pozornost. Predelavo informacij »od spodaj navzdol« pa usmerjajo aktualni dražljaji iz okolja.

Kot osnovno vodilo pri poučevanju mora biti v ospredju preventivna dejavnost, ker obstaja tveganje za morebitne poškodbe, ki so običajno posledica prepletanja več dejavnikov. Preprečevanje morebitnih poškodb je v precejšni meri možno že $z$ ustreznim načrtovanjem in s pravočasnim prilagajanjem izvajanja GŠA glede na okoliščine, pogoje ter glede na udeležence. Prvi korak je lahko objektivna ocena tveganja, ali obstaja možnost (in če obstaja, kolikšna je verjetnost, da se bo dogodek zgodil), da se pripeti nezgodni dogodek.

Obvladovanje tveganj poškodb dosežemo zlasti s primernim organiziranjem in z izvajanjem ter nadziranjem gibalne/športne aktivnosti. Zavedati se moramo tako moralne kot tudi pravne odgovornosti vzgojitelja pri izvajanju gibalne/športne aktivnosti.

Ključni elementi, ki povečujejo zagotavljanje varnosti pri izvajanju gibalnih/športnih aktivnosti, so predvsem:

- sistematično razvijanje prepoznavanja nevarnih situacij pri otrocih, da bodo samostojno vedeli, kje je meja in kako jo določiti,

- sistematično ohranjanje pozornosti in zbranosti,

- vzpostavljanje učnega okolja, v katerem se učenci seznanjajo z načrtnimi »nepredvidenimi « dogodki in z obvladovanjem stresa, ki je pogost spremljevalec zahtevnejših ter novih gibalnih problemov, 
- dosledno upoštevanje zakonodaje,

- ustrezna izbira in raba orodij ter pripomočkov,

- izbor ustreznih metodičnih postopkov,

- izbor primernih didaktičnih pristopov,

- zagotavljanje rabe ustrezne športne opreme,

- izvedba primernega splošnega in specialnega ogrevanja,

- izvajanje komunikacijskega načrta - opozarjanja pred morebitnimi možnostmi poškodb,

- ustrezen izbor športnih vsebin, oblik in intenzivnosti glede na celovite sposobnosti ciljnih skupin,

- optimiziranje rabe športnih prostorov, igrišč, opreme, orodja in rekvizitov kot dejavnik zagotavljanja varnosti,

- primeren izbor športnih prostorov, lokacije, opreme, orodja in rekvizitov glede na gibalno predznanje in razvojno stopnjo ter motivacijo udeležencev programov GŠA in glede na zunanje okoliščine,

- optimalna izraba opreme,

- ustrezen izbor primerne podpore informacijsko-komunikacijske tehnologije pri gibalni/športni aktivnosti,

- izvedba ustrezne prve pomoči, če pride do poškodbe, in

- izdelava zapisnika o nezgodi oz. poškodbi.

Vedno pomembnejši je tudi ustrezen izbor podpore primerne informacijsko-komunikacijske tehnologije pri gibalnem poučevanju, ki lahko prispeva $\mathrm{k}$ zmanjševanju tveganja. 


\section{UČINKOVITO UPRAVLJANJE ŠPORTNE INFRASTRUKTURE}

Poleg primernega načrtovanja športne infrastrukture in opreme ter rekvizitov je potrebno posodabljanje, vzdrževanje in skrbno ravnanje s športno infrastrukturo in opremo. Pomembno je tudi primerno načrtovanje izrabe in koriščenja za gibalne/športne aktivnosti primernih objektov in površin, ki ne smejo ostati neizkoriščeni. Pri tem je v veliko pomoč učinkovita logistika, zlasti pri sestavi učinkovitega urnika uporabe objektov, kar prispeva k optimizaciji športnih prostorov, igrišč, opreme, orodja in rekvizitov. Pomembna sta tudi primerna nabor in izbor športnih prostorov, opreme, orodja in rekvizitov ter drugih inovativnih medijev glede na gibalno predznanje in razvojno stopnjo otrok.

Elemente upravljanja infrastrukture predstavljajo zlasti aktivnosti:

- primerno načrtovanje športne infrastrukture,

- posodabljanje, vzdrževanje in skrbno ravnanje s športno infrastrukturo,

- primerno načrtovanje izrabe in koriščenja,

- učinkovita logistika in

- izvajanje letnih, obdobnih strokovnih preverjanj skladno z zakonodajo in izvajanje pregledov pred vsako uporabo.

Preventivna dejavnost je osnovno vodilo pri poučevanju in organiziranju ter lahko prispeva k preprečevanju morebitnih poškodb, zlasti z ustreznim načrtovanjem in s pravočasnim prilagajanjem izvajanja glede na okoliščine ter 
glede na učence. V primeru nezgode vzgojitelj izpolni poročilo o dogodku primer poročila prikazuje preglednica 7.

\section{Preglednica 7: Primer zapisnika o nezgodi oz. poškodbi}

Podatki o organizaciji, ki je izvajala športno dejavnost

Podatki o vzgojitelju, ki je izvajal aktivnost, pri kateri je prišlo do nezgodnega dogodka

Podatki o poškodovancu

Podatki o nezgodi in nastalih poškodbah udeležencev nezgode

Kraj nezgode

Datum in čas nezgode

Opis vrste poškodbe

Opis okoliščin, v katerih se je zgodila nezgoda

Opis ukrepov za zavarovanje poškodovanca, za nudenje prve pomoči in nadaljnje oskrbe - prevzem poškodovanca, obveščanje skrbnikov in spremstvo

Priloge: Izjave in podatki o morebitnih pričah nezgode, fotografije, dokazi ... 


\section{VSEŽIVLJENJSKO (GIBALNO) UČENJE}

Za razvoj gibalnih kompetenc je zelo pomembno gibalno znanje, ki bo omogočilo učinkovito in avtomatizirano izvedbo gibalnega programa. Pridobivamo ga z vseživljenjskim učenjem, ki ga razumemo kot dejavnost in proces, ki zajema vse oblike poučevanja.

Učenje je lahko formalno ( $v$ šoli smučanja) ali neformalno (smučanje s prijatelji), bodisi aformalno in naključno ali priložnostno s ciljem, da se izboljšajo posameznikovo znanje in spretnosti (prilagojeno po Jelencu, 2007). Formalno gibalno učenje lahko razumemo kot proces pridobivanja gibalnih informacij, ki ga udeleženec lahko zaključi s končnim izidom v obliki priznane pridobljene kvalifikacije, kot npr. pridobitev diplome za usvojeno znanje plavanja, smučanja itd. Neformalno učenje ni namenjeno pridobivanju formalnega izkaza, saj si udeleženec postavlja druge cilje, kot so druženje, zabava, potreba po gibanju itd. Pri naključnem in aformalnem izobraževanju gre za spontano, nenačrtovano in nenadzorovano učenje, ki se praviloma izvaja $v$ neposrednem socialnem in fizičnem okolju, v katerem se nahaja otrok, npr. na dvorišču, igralih, športnem igrišču itd. Kot pove že ime, je za aformalno učenje značilno, da poteka tako brez formalnega okvira kot brez jasnega cilja in namena. Kljub razumevanju poučevanja kot celovitega procesa poučevanja tudi v športni praksi še vedno lahko zasledimo pojmovanje gibalnega poučevanja kot discipliniranja telesa, zato prihaja do nizke motivacije, slabih rezultatov in odpora do gibalnih/športnih dejavnosti. Za vzgojitelje je pomembno, da uveljavljajo sodoben pristop $\mathrm{k}$ pouku $v$ obliki proaktivnega gibalnega poučevanja. Zanj je značilno, da poteka s samostojnim iskanjem in razmišljanjem ter reševanjem 
kakovostno zastavljenih gibalnih problemov, ki otroke vodijo tako do razvijanja njihovih gibalnih sposobnosti kot do pridobivanja uporabnih gibalnih izkušenj in bogatenja gibalnega spomina, kar lahko prispeva k oblikovanju njihovega gibalno oz. športno aktivnega življenjskega sloga. Kompetenten vzgojitelj bo otrokom s postavljanjem in preizkušanjem različnih, iz resničnega življenjskega okolja vzetih gibalnih problemov omogočil učenje, ki jih bo miselno, socialno in čustveno aktiviralo. Tako ponujeno učenje bo omogočilo trajnejše gibalno znanje, spodbujalo bo pozitivne vplive gibalnega transferja, uporabno bo $v$ novih gibalnih situacijah in bo prispevalo $\mathrm{k}$ boljši samopodobi otrok ter $\mathrm{k}$ njihovemu razumevanju sebe in okolja, $v$ katerega bodo znali aktivno posegati. Poleg razvijanja prirojenih gibalnih sposobnosti pa je ključna naloga vzgojitelja na področju gibanja razvijanje pomembnih naravnih gibalnih vzorcev, ki otrokom v nadaljnjem razvoju omogočajo učinkovito usvajanje zahtevnejših gibalnih vzorcev. 


\section{MENEDŽMENT GIBALNEGA RAZVOJA OTROKA}

Športni menedžment je proces koordinacije s ključnimi viri in uspešnega sodelovanja s pomembnimi deležniki, ki omogočajo učinkovito uresničevanje poslovnih in športnih ciljev organizacije in/ali športnika v vseh procesih menedžmenta (Retar, 2014).

Menedžment ali organizacija pouka ima več pomenov in definicij. Menedžment na področju razvoja gibalnega poučevanja otrok razumemo kot proces usklajevanja ključnih dejavnikov, ki omogočajo učinkovito uresničevanje ciljev načrtovanja, organiziranja, izvajanja in vrednotenja gibalnega poučevanja.

Gre za proces maksimiranja možnega, ki povečuje dostopnost do optimalnega gibalnega razvoja otroka za trajnostno vseživljenjsko ravnanje na področju športa - $v$ kontekstu tako razvoja in uporabe kot ohranjanja gibalne kompetentnosti.

Beseda menedžment izvira iz angleškega glagola »to manage«, ki pomeni obvladovanje. Uporabljamo jo tako za označevanje vseh vrst vodenja kot za znanost, ki preučuje menedžment. $V$ teoriji je opredelitev pojma menedžment veliko, vsem pa je skupno spoznanje, da gre za menedžment z različnimi viri, ki so vitalnega pomena za uresničevanje ciljev $v$ temeljnih funkcijah menedžmenta (Daft, 2003). Na področju gibalnega poučevanja menedžment razumemo kot celovit proces usklajevanja ključnih dejavnikov, ki omogočajo učinkovito uresničevanje ciljev načrtovanja, organiziranja, izvajanja in nadziranja gibalnega poučevanja ter $\mathrm{z}$ njim povezanih dejavnosti. 
V literaturi zasledimo različne opredelitve menedžmenta v športu (Chelladurai, 1994; Bartoluci, 1997; Daft, 2003; Houlihan, 2008; Lussier in Kimball, 2004; Parks in Qurterman, 2002), večina pa jih poudarja, da ta temelji na ravnanju s ključnimi viri, ki so pomembni za uresničevanje poslanstva in ciljev športne organizacije, prireditve ali športnika. Splošna opredelitev, ki bi enoznačno opredelila pojem menedžment v športu, še ne obstaja. Menedžment poučevanja skuša odgovoriti na ključna vprašanja pri temeljnih poslovnih funkcijah:

- Načrtovanje - kaj, zakaj in koliko ter po čem?

- Organiziranje - kako?

- Izvajanje - kdo, na kakšen način, kje, kdaj in s katerimi sredstvi?

- Nadzorovanje - ali smo dosegli pričakovane izide?

Cilj upravljanja gibalnega razvoja otrok je spoznati osnove gibalnega razvoja otroka in posebnosti, ki ga v tem procesu razlikujejo od odraslega, ter razumeti proces regulacije gibanja $v$ hierarhiji strukture gibalnega prostora otroka v zgodnjem obdobju kot osnovo gibalnega poučevanja (Pišot, 2012). Da bi bili pri svojem delu učinkovitejši, lahko uveljavljamo izbrane pristope iz športnega menedžmenta. Za naše potrebe lahko menedžment na področju razvoja gibalne kompetentnosti otrok razumemo kot proces usklajevanja ključnih dejavnikov, ki omogočajo učinkovito uresničevanje ciljev načrtovanja, organiziranja, izvajanja in nadziranja gibalnega poučevanja.

Ključna področja menedžmenta poučevanja so:

- profesionalni razvoj kadrov;

- izobraževalni in kadrovski menedžment;

- menedžment učnih dogodkov;

- menedžment kakovosti v poučevanju.

Menedžment poučevanja lahko razdelimo na naslednje ravni:

- profesionalni razvoj kadrov z izmenjavo dobrih učnih praks;

- inovativni učni postopki;

- kakovosten prikaz gibanja s podporo informacijsko-komunikacijske tehnologije;

- učinkovita komunikacija s spodbujanjem;

- optimizacija učnega procesa s skupinsko učno metodo in kombiniranimi učnimi oblikami;

- spodbujanje zdravega življenjskega sloga. 


\section{STA KAKOVOST IN UČINKOVITOST EDINA KAZALNIKA?}

Sodobno gibalno poučevanje $v$ središče postavlja učenca, učitelja/vzgojitelja pa opredeljuje kot profesionalca, ki obvladuje učni proces in samorefleksijo, s katero ugotavlja, ali je izpolnil pričakovanja učencev/otrok in drugih pomembnih deležnikov.

Vzgojiteljevo ključno delo na področju gibanja je učinkovito in prijazno spreminjanje podedovanih gibalnih potencialov otroka $v$ zgodnjem otroštvu $v$ resničnostno gibanje, ki je obogateno $z$ otrokovo unikatnostjo. $V$ neoliberalnem poslovnem modelu delovanja družbe je pomemben kazalnik uspešnosti učinkovitost, tudi na področju menedžmenta gibalnega poučevanja, pri čemer menedžment razumemo kot celovit proces usklajevanja ključnih dejavnikov načrtovanja, organiziranja, izvajanja in nadziranja gibalnega poučevanja. Pogosto so ti kazalniki precenjeni, ker je gibalno poučevanje $v$ zgodnjem otroštvu naložba, in mejniki, s katerimi primerjamo stopnjo razvitosti, ne kažejo prave podobe in potenciala posameznika, zato moramo biti pri napovedovanju obsega razvoja seveda zadržani.

Prav tako postaja trendovsko spodbujanje vseživljenjskega poučevanja za zdrav življenjski slog, ki med drugim lahko postane tudi prikrita oblika potrošništva, pri čemer zdrav življenjski slog lahko razložimo kot skupinske vzorce zdravju prijaznega obnašanja posameznika, ki temeljijo na človekovih izbirah in možnostih glede na njegove življenjske priložnosti (Cockerham, 2005). Zaradi življenjsko ogrožajočega pomanjkanja kakovostnega gibanja, zlasti pri mladostnikih (Jeriček Klajnšček idr., 2015; Gabrijelčič Blenkuš, 2013), (p)ostaja vse pomembnejša vloga učitelja. Ugotovitve mednarodne raziskave »Z zdrav- 
jem povezana vedenja $v$ šolskem obdobju med mladostniki v Sloveniji namreč kažejo, da se kažejo negativni trendi pri deležih redno telesno dejavnih, uporabe elektronskih naprav in mladih, ki redno doživljajo več različnih psihosomatskih simptomov (Jeriček Klajnšček idr., 2015). Slovenski otroci imajo tudi prekomerno telesno maso, ki lahko ogroža njihovo zdravje (Gabrijelčič Blenkuš, 2013). Pri otrocih še zaznavamo kineziofobijo kot neutemeljen strah pred gibanjem, ki je lahko posledica negativnih gibalnih izkušenj in ga je možno s primernimi postopki odpraviti.

Za objektivno spremljanje delovne uspešnosti so nam lahko v podporo naslednji kazalniki:

- vložen čas vzgojitelja v poučevanje,

- participacija otrok,

- usklajenost učne vsebine z gibalno kompetentnostjo otroka,

- usklajena pričakovanja med otroki,vzgojitelji in deležniki,

- nastali materialni stroški,

- obvladovanje tveganj športnih poškodb,

- raven doseženih izidov.

Ključni namen menedžmenta gibalnega poučevanja na področju gibanja je razvijanje gibalnih sposobnosti in spretnosti, ki pripomorejo k učinkovitejšemu in bolj nadzorovanemu gibanju ter omogočajo oblikovanje zdravega življenjskega sloga. Hkrati ne smemo prezreti dejstva, da je gibalni razvoj tudi tesno povezan s kognitivnim in čustveno-socialnim področjem otrokovega razvoja.

Poslanstvo vrtca kot vzgojno-izobraževalne institucije in vzgojitelja kot kompetentnega mentorja je postati ključni prostor socializacije in vzgoje, tudi gibalne. Poleg pozitivnih učinkov gibanja ne smemo prezreti prvinske vloge gibanja v otroštvu - ustvarjanje igre, zgodbe, doživetja. Gibalne aktivnosti naj ostanejo igra in ne, kot je danes popularno, da je gibanje le $v$ funkciji vzgoje, izobraževanja, zdravja, potrošništva, pri čemer ne sme motiti, biti nevarno ter samo sebi namen... 


\section{IZHODIŠČNE USMERITVE KAKOVOSTNE IN UČINKOVITE GIBALNE OBRAVNAVE OTROK}

Če želimo učinkovito in pozitivno vplivati na gibalni razvoj otroka, potem moramo biti še posebej pozorni na:

I. obvladovanje strukture telesne mase $z$ ustreznim prehranjevanjem, s hidriranjem in primernim gibanjem;

II. krepitev mišic ramenskega obroča;

III. krepitev mišic stabilizatorjev trupa;

IV. podpiranje zdrave in optimalne telesne drže;

V. razvijanje splošne in specialne telesne zmogljivosti;

VI. spodbujanje in uveljavljanje zdravega in aktivnega življenjskega sloga.

Pozitivni pristopi pri prvih korakih v gibanju in kasnejši mehak prehod $v$ šport so najpomembnejši.

V ospredju razvoja v prvih letih življenja je nagel razvoj senzorne in gibalne funkcije otroka. V tem obdobju se razvijata vzporedno oz. odvisno. Za uspešnost faze je treba zagotoviti primerno količino senzorne spodbude pa tudi možnost gibalnega izražanja. Kasneje gibalni razvoj poteka bolj ali manj kontinuirano in s posameznimi razvojnimi mejniki. Med šestim in desetim letom se telesna rast upočasni, intenzivneje rastejo mišice, stopnja razvitosti koordinacije gibanja pa predstavlja idealen čas za začetek splošne športne vadbe oz. za intenzivno vadbo tehnično zahtevnejših športov in kompleksnejših gibalnih storitev. Zaradi hitrega razvoja velikih možganov in predvsem procesa mielinizacije korteksa je to čas optimalnega poučevanja gibalnih dejavnosti, ki 
zahtevajo veliko naučenih gibalnih vzorcev (gimnastika, balet, smučanje, plavanje itd.).

Sistematično vplivamo na otrokov gibalni razvoj s procesom gibalne/ športne vzgoje v vzgojno-izobraževalnem sistemu, pomemben vpliv pa imajo tudi otrokove prostočasne dejavnosti v primarnem družinskem okolju in kasneje $z$ vrstniki v športnih klubih.

Gibalna obravnava je celostna obravnava posameznika z vsebinami in s sredstvi gibanja, upoštevajoč posebnosti, zmožnosti in omejitve, ki posameznika gibalno opredeljujejo, ter vplive - posledice gibanja v interakciji z okoljem na posameznika.

V primeru, da bo otrok pri športu doživljal negativna čustva, bo šport dobil predznak negativne asociacije. Slaba športna vadba bo zato otroka za vedno odvrnila od športa, zato naj bo športna vadba za otroke zabavna in naj jim bo v užitek. Šport lahko opredelimo tudi kot potrebo. Dobra športna vadba sprošča hormone, ki aktivirajo motive, ki bodo izzvali potrebo po športu. Dobra športna vadba bo povzročila čustva veselja, zadovoljstva; slaba športna vadba bo genetsko prirojeno potrebo po igri, gibanju, športu zavirala, morda celo zatrla. Otrokov svet ni enak svetu odraslih, ker kar je dolgočasno odraslemu, ni nujno dolgočasno tudi otroku, zato je treba skrbno pretehtati, kaj je primerno in pozitivno za otroke, zlasti skozi njihov pogled na svet. Otroci so počasnejši, zanje je vse novo, radi ponavljajo iste stvari, na njihovo dobro počutje pa vplivajo tako okolje, objekt in izbor rekvizitov kot vsebina in oblika gibalnih/športnih dejavnosti. 


\section{NAČINI RAZVIJANJA GIBALNE KOMPETENTNOSTI OTROK S POMOČJO ELEMENTARNIH GIBALNIH VZORCEV}

Pri najmlajših otrocih začenjamo s sistematičnim delom, zlasti z uporabo številnih prilagojenih gibalnih oblik, ki jih črpamo iz naravnih oblik gibanja. To so filogenetska, prirojena gibanja in t. i. elementarna gibanja, ki praviloma zasledujejo samo cilj ter ne učni proces kot pri športu, kjer so poleg tega vospredju še kakovost, rezultat in presežek ali zmaga. Med elementarna gibanja ali gibalne vzorce uvrščamo predvsem različna plazenja in lazenja, hojo in tek, plezanja in skoke ( $v$ daljino, višino, globino), različne oblike padcev in kotaljenj ter zvrnitev, mete in lovljenja predmetov, udarce in blokade udarcev, prav tako vse vrste prijemov, potiskanja, vlečenja, upiranja, dviganja ter nošenja. Dolgoletno rutinsko prakso postavljanja mejnikov, kaj otroci v določenem starostnem obdobju že zmorejo, je zamenjala nova paradigma, kjer učitelj otrokom postavlja gibalne izzive in probleme, otrokove rešitve pa učitelju omogočajo, da prepozna gibalne sposobnosti in sledi otroku ter mu omogoča nadgradnjo v njegovem gibalnem razvoju z novimi, zahtevnejšimi gibalnimi izzivi.

Naravne oblike gibanja nadgrajujejo sestavljena gibanja, ki poleg cilja zasledujejo še kakovost in so usmerjena v maksimalno dejavnost. So nadgradnja naravnih oblik gibanja ter predstavljajo zapletenejša in strukturirana gibanja v obliki gibalnih stereotipov, ki so ontogenetsko pogojena gibanja - tj. naučena - in vsebujejo poleg cilja še oblikovanje kakovostne izvedbe, kot npr. plavanje, kolesarjenje, smučanje.

Med pomembne elemente spada primerna struktura vadbene enote razvijanja, ohranjanja in krepitve gibalnih sposobnosti, ki jo sestavljajo uvodni 
oz. motivacijski in ogrevalni del, glavni oz. storilnostno in razvedrilno usmerjeni del, zaključni oz. umiritveni del in zadnji oz. evalvacijski del vadbene enote.

\section{Ogrevanje}

V uvodnem delu vadbene enote priporočamo za vse starostne kategorije predšolskih otrok:

- različne oblike hoje in teka;

- skoke in lazenja;

- nekatere dinamičnejše oblike plazenj, vlečenj in nošenj;

- mete;

- lovljenja predmetov;

- prijeme partnerja.

Z dobro »zgodbo« lahko otroke bolje in lažje pritegnemo k sodelovanju ter so zato lahko gibalno učinkovitejši, s tem pa hitreje in uspešneje uresničimo vzgojne in izobraževalne cilje. Razvoj gibalnih sposobnosti, ki ga praviloma izvajamo v glavnem delu vadbene enote, je najpomembnejši.

Osmislitev gibanja z otrokom prijaznimi in razumljivimi pristopi v obliki zgodbe, kot npr. oponašanje živali (plazimo se kot polž), naravnih pojavov (zibamo se v vetru) ipd., lahko pozitivno vplivajo na gibalni razvoj.

Z vnaprej načrtovanimi ter razvojni stopnji, gibalnim sposobnostim in motivaciji prilagojenimi ustreznimi gibalnimi problemi, ki jih otrok samostojno rešuje, se lahko vpliva na razvoj:

- $\quad$ moči - z vsemi oblikami elementarnih in sestavljenih gibanj ter njihovih kombinacij, ob ustrezni individualni obremenitvi vadečih (uporaba lahkih bremen);

- $\quad$ koordinacije - z izvajanjem zapletenejših in neobičajnih gibalnih nalog;

- hitrosti - s hitrim izvajanjem teka, lazenja in plezanja ter različnih metov, udarcev in blokad;

- ravnotežja - z gibanji na zmanjšani podporni ploskvi (hoja, tek, lazenja, vlečenja, potiskanja, nošenja);

- natančnosti - z natančno izvedbo teka, lazenja, skokov in padcev ali pri manipulacijah zadevanja cilja (meti, lovljenja);

- gibljivosti, ki pa se lahko razvija le v manjši meri oz. se lahko le ohranja z doseganjem velikih amplitud gibov, npr. pri plazenju, lazenju in nekaterih oblikah plezanj. 
Pridobivanje gibalnih informacij in utrjevanje gibalnih spretnosti

Uporabljajo se pri učenju novih gibalnih struktur in pri utrjevanju že naučenih, pri čemer se lahko uporabijo vse oblike, ki so vadečim manj znane. $Z$ njihovim večkratnim ponavljanjem se pridobivajo gibalna znanja oz. t. i. gibalne spretnosti. Psihofizična umiritev se izvaja v zaključnem delu vadbene enote za vse starostne skupine. $V$ ta namen se uporabljajo gibanja, ki energijsko niso zahtevna in niso predinamična: hoja, plazenja, lazenja in različne manipulacije s predmeti. 



\section{INOVATIVNO GIBALNO POUČEVANJE KOT DODANA VREDNOST}

Kakovostno, inovativno in na refleksiji utemeljeno gibalno poučevanje $v$ zgodnjem obdobju lahko pospešuje gibalni razvoj ter vodi v optimalno gibalno kompetentnost otroka. Poučevanje v družbi znanja se spreminja in z njim vloga učitelja.

Medved Udovič, Cotič in Cencič (2008, str. 9) ugotavljajo: »Učitelj ni več le prenašalec znanja, temveč moderator, animator, organizator spodbudnega učnega okolja, mentor in spodbujevalec samostojnega poučevanja."

Učeča se družba je izziv za vse vzgojitelje, ki vedo, da je učenje za osebnostni razvoj v postavljanju izzivov vsakemu izmed učencev. Dumont, Istance in Benavides (2010) so izostrili učna načela, ki kažejo, da bi morale šole za svojo čim večjo učinkovitost med drugim v središče postaviti učenje, spodbujati udejstvovanje in zagotavljati, da je učenje družabno ter pogosto sodelovalno.

Zato vzgojitelji razumno in ne brez premisleka v središče postavljajo otroka, sebe pa vidijo kot profesionalca, ki obvladuje učni proces in samorefleksijo, s katero ugotavlja, ali je izpolnil pričakovanja otrok in drugih pomembnih deležnikov vzgoje in izobraževanja. Poročilo o inovativnih učnih okoljih (OE$C D$, 2013) je med razsežnosti, s katerimi šole inovirajo strukture in dinamike poučevanja, uvrstilo zlasti raznolikosti v prepletanju pedagoških prijemov, ki $z$ dobrim poučevanjem pritegne učence $k$ udejstvovanju ter uresničuje prilagajanje posamezniku, izboljševanje reševanja problemov in krepitev skupinskega dela. 


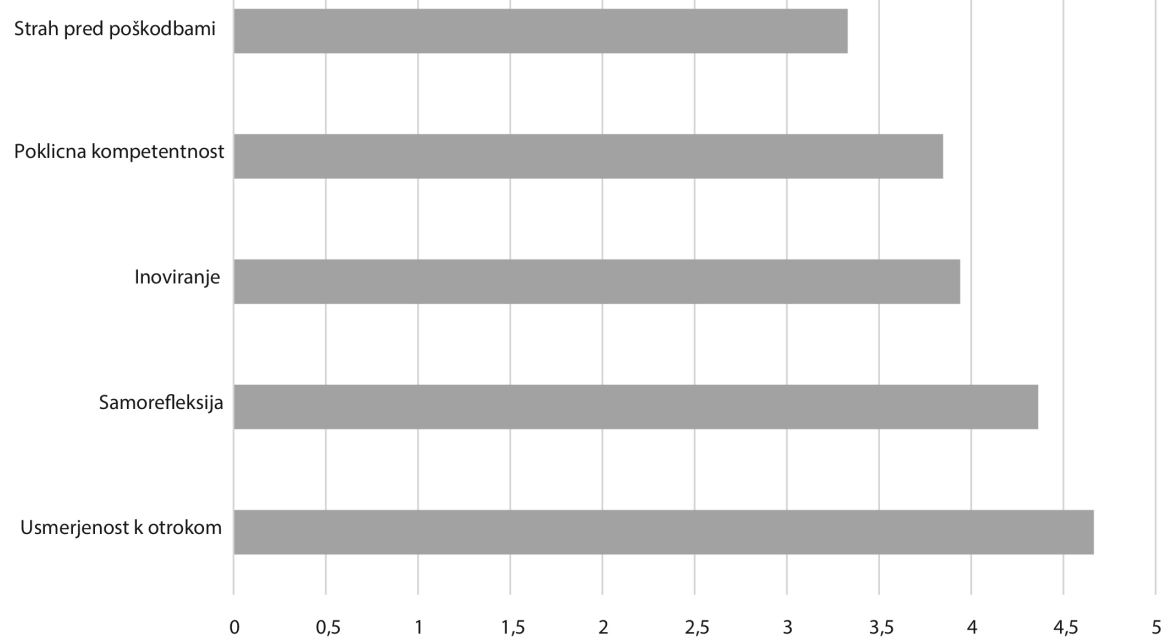

Slika 3: Ocena področij delovanja vzgojiteljev, ki prispevajo k inovativnosti na področju zgodnjega gibalnega poučevanja v praksi (Retar, Štemberger in Lepičnik Vodopivec, 2018)

Gibalno učenje, zlasti v zgodnjem otroštvu, je kompleksen proces s številnimi interakcijami, ki omogoča izvedbo spontanih in tudi skrbno načrtovanih gibalnih nalog/problemov s ključnim ciljem, da pomembno pripomorejo tako k uspešnemu razvoju gibalnih sposobnosti otroka kot k usvajanju elementarnih gibalnih vzorcev in gibalnih stereotipov ter prispevajo k oblikovanju trajnostne gibalne kompetentnosti otroka. Ker ostanejo pridobljeni gibalni programi trajno zapisani v gibalnem spominu, je pomembno, da imajo otroci čim prej dostop do spodbudnega okolja za gibanje, v katerem bodo pridobili čim več raznolikih gibalnih informacij in možnosti kakovostnega reševanja gibalnih problemov, s katerimi bodo lahko učinkovito razvijali svoje prirojene gibalne sposobnosti, oblikovali nove ter ohranjali in nadgrajevali že pridobljene gibalne programe.

Cilj inovativnega pristopanja je spodbuditi ustvarjalnost vzgojiteljev pri iskanju izboljšav pri gibalnem učenju in uvajanju gibalnih/športnih dejavnosti zlasti na organizacijskem področju - menedžmentu športa v okolju vrtca kot tudi pri iskanju novih učinkovitih učnih strategij.

Za vzgojitelje v vrtcih in vzgojitelje v svetu športa je pomembno, da uveljavljajo sodoben pristop k pouku v obliki proaktivnega gibalnega poučevanja. Zanj je značilno, da poteka s samostojnim iskanjem in razmišljanjem ter z reševanjem kakovostno zastavljenih gibalnih problemov, ki učence vodijo 
do optimalnega razvijanja njihovih gibalnih sposobnosti in kompetentnosti, pridobivanja uporabnih gibalnih izkušenj, ki lahko prispevajo k oblikovanju njihovega trajnostnega športnega življenjskega sloga, in zadovoljstva pri gibanju. Za učinkovito učenje je pomembno, da vzgojitelji zagotavljamo pozitivno, varno in ustvarjalno okolje, $v$ katerem je veliko raznolikih in praktičnih vsebin (Retar idr., 2014).

Preglednica 8: Model inovativnega gibalnega poučevanja (Retar, 2015)

\section{P - POVPRAŠEVANJE}

Vzgojitelj učence $v$ središče učnega procesa umešča z didaktičnim pristopom, ki je prilagojen učencem - sledi njihovim povpraševanju in pričakovanjem ter tako povečuje učinkovitost poučevanja.

Vzgojitelj sledi pričakovanjem ključnih deležnikov: države v obliki kurikula, staršev v obliki dodatnega, dopolnilnega in interesnega pouka ter $v$ civilni športni družbi v obliki športnih krožkov.

\section{P - PRILAGAJANJE, POENOSTAVLJANJE}

Vzgojitelj organizira učni proces tako, da vanj enakopravno vključi tako učence, ki so gibalno nadarjeni, kot učence $s$ težavami v gibalnem razvoju in gibalno ovirane učence s prilagoditvami in pomočjo. Vzgojitelj prilagaja in poenostavlja programe skladno s ključnimi pravili športne in drugih mejnih strok. Najpogostejša so: poenostavitev pravil igre, brez štetja točk, pri igri ni napak, mehkejši športni pripomočki ...

P - PONUDBA

Vzgojitelj v ponudbo poleg kakovostne uporabniške gibalne izkušnje vključuje še specifične programske vsebine v okviru možnosti lokalne, regionalne in nacionalne tradicionalne športne oblike (discipline), infrastrukturo in športno izročilo kot primerjalne prednosti za uveljavljanje učinkovitega poučevanja.

P - PODPORA IN POMOČ

Vzgojitelj s specialno komunikacijo spodbuja, usmerja in nadzira učenca na poti do njegovega osebnega cilja na področju gibanja. Z multimedijsko demonstracijo in podporo informacijsko-komunikacijske tehnologije prispeva k večji učinkovitosti, merljivosti in zanimivosti tako na področju gibalnega poučevanja kot gibalnih dejavnosti nasploh. Uporablja inovativne medije: igrače, športne pripomočke in pomagala, mnoge lahko tudi ustvari skupaj z otroki. Kot pomoč pri vzpostavljanju ter ohranjanju pozornosti in koncentracije uporablja vizualna navodila (plakati, slike, lutke) zvočna (glasbila, posneta glasba, pesmice ...), označevanje smeri gibanja in preusmeritve pozornosti (kognitivna vadba ...), označevanje prostora z različnimi barvami .

Sodobni vzgojitelji na področju gibalnih/športnih dejavnosti bomo pri svojem delu lahko uspešnejši, če bomo poučevanje razumeli kot proaktivno, ustvarjalno in na praksi temelječe spreminjanje posameznika skladno s priča- 
kovanimi učnimi izzivi v ugodnem učnem okolju. Uvajanje priporočil iz modela štirih P-jev - povpraševanje, prilagajanje, ponudba in podpora - lahko prispeva $\mathrm{h}$ kakovostnejšemu in k učinkovitejšemu delu vzgojitelja pri športu (Retar, 2015). Z uresničevanjem modela bomo lahko še dodatno prispevali k temu, da bo gibalna/športna dejavnost pozitivno vplivala na celostni razvoj otroka in sooblikovala njegov zdrav trajnostni življenjski slog. Tovrstni pristop lahko tudi podpira poučevanje, ki je otrokom varno, všečno in prijazno ter zato tudi učinkovito.

\section{PREDNOSTI INOVATIVNEGA GIBALNEGA POUČEVANJA}

Sodobna inovativna didaktična načela lahko pouk naredijo kreativnejši, dinamičnejši, prilagodljivejši in razvojno se spreminjajoč ter uvajajo didaktično načelo o vseživljenjskosti poučevanja oz. povezavo teorije in prakse, avtonomijo vzgojitelja, kompetenčni pristop, odprtost in izbirnost vsebin, učno-ciljni in procesno-razvojni pristop, fleksibilnost učnega procesa, medpredmetni pristop k učenju in poučevanju, kakovost znanja na vseh taksonomskih ravneh (poglobljeno, povezano in uporabno znanje), prilagoditev načinov dela vsem učencem, zlasti pa učencem s posebnostmi v gibanju, samostojnost in odgovornost učencev za lastno znanje, razvojno spremljanje učenčevih rezultatov ter poglobljeno sodelovanje staršev in drugih deležnikov.

Vzgojitelji lahko inovacije, nasploh novosti, prepogosto zaznamo kot napako v našem didaktičnem formatu delovanja, zato smo zadržani ter odklonilni in se radi vračamo k rutini. Spoznanje, da je inoviranje dodana vrednost naše prakse in ne napaka, nam lahko pomaga pri prepoznavanju novih uspešnih didaktičnih postopkov, ki bodo izboljšali učno izkušnjo otrok.

V raziskavi so strokovnjaki (Retar idr., 2018) ugotavljali, kakšna so stališča slovenskih vzgojiteljev do pomembnosti nalog, ki lahko prispevajo k učinkovitemu in inovativnemu zgodnjemu poučevanju, in katere so njihove najpogostejše prakse na področju inovativnega gibalnega poučevanja. V raziskavo so neslučajnostno in namensko vključili 388 vzgojiteljic predšolskih otrok, ki delujejo v vrtcih. Izsledke so predstavili v mrežni matriki štirih kvadrantov. Rezultati (preglednica 9) so pokazali, da vzgojitelji kot najpomembnejše in nujne naloge v praksi opredeljujejo dejavnosti, ki so povezane s prijetnim počutjem otrok in samorefleksijo. Nujni, ampak manj pomembni dejavnosti sta izvajanje inovativnih učnih praks ter preizkušanje novih pristopov pri poučevanju. Dejavnosti, ki so pomembne, ampak niso nujne, so razvoj poklicne kompetentnosti, participacija otrok pri načrtovanju dejavnosti in previdnost pri ak- 
tivnostih v povezavi s strahom pred pritožbami staršev. Med naloge, ki niso tako pomembne, ampak so nujne, so dejavnosti, vezane na usklajenost učne vsebine z gibalno kompetentnostjo otroka. Med dejavnosti, ki sicer lahko podpirajo inovativno poučevanje, niso pa zelo pomembne in jih prav tako ni potrebno nujno izvesti, so anketiranci uvrstili obvladovanje tveganj športnih poškodb. Elementom, ki tvorijo matriko, je skupna usmerjenost v preizkušanje novih postopkov poučevanja ter osredotočenost na otroka in izide procesa poučevanja. S predstavljeno matriko lahko spodbudimo in usmerjamo nadaljnje razvijanje inovativnega zgodnjega gibalnega poučevanja, ki lahko prispeva h krepitvi gibalne kompetentnosti otrok.

Preglednica 9: Struktura modela faktorjev delovanja in nalog, ki jih vzgojiteljice izvajajo v praksi in lahko prispevajo k inovativnosti na področju zgodnjega gibalnega poučevanja (Retar idr., 2018)

\begin{tabular}{|c|c|c|c|c|c|}
\hline \multirow[b]{2}{*}{ Trditev } & \multicolumn{5}{|c|}{ Področje } \\
\hline & 1 & 2 & 3 & 4 & 5 \\
\hline Preizkušanje novih postopkov pri poučevanju. & 809 & & & & \\
\hline Razvijanje novosti v praksi & 796 & & & & \\
\hline Prenos novosti v prakso. & 776 & & & & \\
\hline Sprejemanje odgovornosti za novosti pri poučevanju & ,628 & & & & \\
\hline Izmenjava dobrih praks & ,604 & & & & \\
\hline Participacija otrok pri načrtovanju dejavnosti & 487 & & & & \\
\hline $\begin{array}{l}\text { Uporaba različnih materialov, pomagal, pripomočkov, } \\
\text { medijev }\end{array}$ & 439 & & & & \\
\hline Razmislek o tem, kaj ni bilo dobro izpeljano & & 911 & & & \\
\hline Razmislek o tem, kaj je bilo dobro izpeljano & & 905 & & & \\
\hline Razmislek o tem, kako bi ravnali v prihodnje & & ,887 & & & \\
\hline $\begin{array}{l}\text { Pridobivanje novih poklicnih kompetenc na področju } \\
\text { gibanja }\end{array}$ & & & 864 & & \\
\hline Postavljanje novih poklicnih izzivov & & & 829 & & \\
\hline Prijetno počutje otrok & & &, 778 & & \\
\hline Uporaba ustaljenih postopkov pri poučevanju & & & & ,863 & \\
\hline Strpnost pri delu z otroki & & & & 834 & \\
\hline $\begin{array}{l}\text { Previdnost pri aktivnostih v povezavi s strahom pred } \\
\text { pritožbami staršev }\end{array}$ & & & & & 874 \\
\hline $\begin{array}{l}\text { Izogibanje aktivnostim, pri katerih se otroci lahko } \\
\text { poškodujejo }\end{array}$ & & & & & ,816 \\
\hline
\end{tabular}


Dobljene rezultate so implementirali v prilagojeno Eisenhowerjevo mrežno matriko štirih nalog inovativnega zgodnjega gibalnega poučevanja in $s$ tem pred teoretike in praktike postavili nove izzive za raziskovanje obravnavanega področja. V prvem kvadrantu so navedene ključne naloge, ki so pomembne ter nujne in jih moramo opraviti, če želimo uveljaviti inovativno obliko poučevanja, kot je, denimo usmerjenost k otrokom $(M=4,66)$ in samorefleksija $(M=4,36)$. V drugem so naloge, ki so sicer pomembne, ampak niso nujne in jih lahko odložimo ter opravimo v kasnejših učnih etapah, recimo razvoj poklicne kompetentnosti $(M=3,84)$. Vendar moramo biti pri tovrstnih opravilih previdni glede časovnice, da jih ne odlagamo predolgo, ker gre še vedno za zelo pomembne naloge. $V$ tretjem kvadrantu so naloge, ki niso tako pomembne, vendar so nujne, kot je npr. prakticiranje inoviranja $(M=3,94)$. V zadnjem kvadrantu so naloge, ki sicer lahko podpirajo inovativno poučevanje, niso pa ne zelo pomembne in jih prav tako ni potrebno nujno izvesti, denimo naloge, ki jih ne izvajamo zaradi prisotnosti strahu pred poškodbami ot$\operatorname{rok}(M=3,33)$, (Retar idr., 2018).

\begin{tabular}{|c|c|c|}
\hline & Nujno v praksi & Ni nujno v praksi \\
\hline Pomembno v praksi & $\begin{array}{l}\text { I. SAMOREFLEKSIJA } \\
(M=4,36)\end{array}$ & $\begin{array}{l}\text { II. USMERJENOST K } \\
\text { OTROKOM } \\
(M=4,66)\end{array}$ \\
\hline Ni pomembno v praksi & $\begin{array}{l}\text { III. PRAKTICIRANJE } \\
\text { INOVIRANJA } \\
(\mathrm{M}=3,94)\end{array}$ & $\begin{array}{l}\text { IV. STRAH PRED } \\
\text { POŠKODBAMI OTROK } \\
(\mathrm{M}=3,33)\end{array}$ \\
\hline
\end{tabular}

Slika 4: Mrežna matrika inovativnega zgodnjega gibalnega poučevanja (Retar idr., 2018) 


\section{SPODBUJANJE VSEŽIVLJENJSKEGA POUČEVANJA ZA ZDRAV ŽIVLJENJSKI SLOG}

Ko s primernim načinom življenja zmanjšujemo negativne pojavne oblike sodobnega stresnega življenja, govorimo o zdravem življenjskem slogu, ki ga razumemo kot izbrane skupinske vzorce zdravju prijaznega obnašanja posameznika, temelječe na izbirah in možnostih glede na njegove življenjske priložnosti (Cockerham, 2005). Nanj otroci težko vplivajo sami, zlasti z vidika zdravega delovanja posameznika, zato je vloga vzgojitelja neprecenljiva. Prav tako lahko vzgojitelj kot družbeno odgovoren strokovnjak posredno vpliva na družbo, ki ima veliko moč pri otrokovi izbiri, da bo otroke zaščitila pred številnimi negativnimi vplivi, predvsem neprimernega prehranjevanja, prekomerne uporabe IKT-naprav in splošnega pomanjkanja gibanja. Kompetentnejši kot so otroci za oblikovanje zdravega življenjskega sloga, uspešnejši so lahko pri razvijanju ter krepitvi zdravja in spopadanju s sodobnimi negativnimi družbenimi pojavi.

Če kvantitativno pojmovanje poučevanja razumemo kot skladiščenje neživljenjskega znanja, ga moramo nadgraditi s kvalitativnim razumevanjem poučevanja kot spreminjanja samega sebe. Tako spreminjamo sebe kot osebnost in posledično pridobivamo nove kompetence, krepimo obstoječe ter postajamo vse kompetentnejši za kakovostno življenje, kar je za sodobno in na liberalnem poslovnem modelu temelječo družbo znanja še posebej pomembno (Retar, 2015). Med pomembne delovne kompetence vzgojiteljev spada vseživljenjsko učenje, zato je kot osebna in strokovna rast vzgojitelja pomembno stalno strokovno usposabljanje. Prav tako k strokovni rasti vzgojitelja prispeva stalno preizpraševanje ter ugovarjanje ustaljenim učnim praksam in ritualom 
sodobnih vzgojno-izobraževalnih sistemov, pedagoških strategij, didaktičnih postopkov in učnih dinamik. 


\section{PRIMERI SLABE PRAKSE PRI GIBALNEM POUČEVANJU}

Kompetenten vzgojitelj bo lahko s postavljanjem in preizkušanjem različnih, iz resničnega življenjskega okolja vzetih gibalnih problemov omogočil učen$\mathrm{je}$, ki bo otroke miselno, socialno in čustveno aktiviralo.

Za tovrstno učenje je značilno, da poteka s samostojnim iskanjem in razmišljanjem ter $z$ reševanjem kakovostno zastavljenih gibalnih problemov, ki otroke vodijo tako do razvijanja njihovih prirojenih gibalnih sposobnosti kot do pridobivanja uporabnih gibalnih izkušenj. Le-te lažje in učinkoviteje omogočajo njihove vrhunski gibalne storitve in hkrati pozitivno prispevajo k oblikovanju njihovega športnega življenjskega sloga.

Kljub razumevanju gibalnega poučevanja kot celovitega procesa poučevanja tudi v športni praksi še vedno lahko zasledimo pojmovanje gibalnega poučevanja kot discipliniranje telesa, prezgodnje selekcioniranje domnevno najperspektivnejših otrok, klientelizem, nepotizem, korupcijo, doping in prezgodnje uvajanje trenažnega procesa zato lahko prihaja do nizke delovne motivacije, slabših rezultatov, športnih poškodb (Samardžija Pavletič idr., 2014) in posledično tudi do odpora do gibalnih/športnih aktivnosti ter nenazadnje do osipa.

Današnji uspešni vzgojitelji kot odgovor na predstavljene probleme uveljavljajo pristop trajnostnega proaktivnega gibalnega poučevanja. Gibalno učenje, ki bo učenece miselno, socialno in čustveno aktiviralo, bo omogočilo hitrejše usvajanje gibalnih znanj, trajnejše gibalno znanje, spodbujalo bo pozitivne vplive gibalnega transfera in bo uporabno v novih gibalnih situacijah. Prispevalo bo $\mathrm{k}$ boljši samopodobi učencev ter njihovemu razumevanju sebe 
in okolja, v katerega bodo znali samostojno aktivno posegati in jim bo omogočilo optimalen razvoj gibalnih dosežkov ter užitkov v gibanju.

Za izvajalce storitev na področju vzgoje in izobraževanja v zgodnjem otroštvu je pomembno, da uveljavljajo sodoben pristop k poučevanju v obliki proaktivnega gibalnega poučevanja. Zanj je značilno, da poteka s samostojnim iskanjem in razmišljanjem ter z reševanjem kakovostno zastavljenih gibalnih problemov, ki otroke vodijo do optimalnega razvijanja njihovih gibalnih sposobnosti in kompetentnosti ter pridobivanja uporabnih gibalnih izkušenj, ki lahko prispevajo k oblikovanju trajnostnega zdravega/športnega življenjskega sloga ter zadovoljstva pri gibanju.

V nadaljevanju si oglejmo nekaj izbranih najpogostejših napak pri gibalnem poučevanju, z namenom, da se izognemo slabi praksi.

\section{Področje zagotavljanja varnosti:}

- Fizično (npr. napačno postavljene blazine, prekratka varnostna razdalja ...)

- in didaktično (npr. nejasna navodila, gibalno učenje brez demonstracije, prevelike in neobvladljive skupine, napačno izbrane gibalne naloge ...)

\section{Neusklajena struktura vadbene ure:}

- Napačna izbira načrtovanja: obremenitev - odmor - obremenitev,

- brez nadgradnje znotraj naloge pri obremenitvi,

- brez vključevanja aktivnega odmora in regeneracijskih tehnik,

- Šibko zagotavljanje uravnoteženosti - informacijska ali energijska komponenta nista usklajeni,

- brez uvodnega ali zaključnega dela in

- brez evalvacije.

\section{Strukturne metodološke napake:}

- Podcenjevanje ali precenjevanje otrok,

- površno gibalno poučevanje - jedrnata razlaga, nazoren prikaz gibanja, spodbudno usvajanje primernih gibalnih vzorcev in gibalnih nalog,

- neskladnost ciljev vadbene enote z izbranimi nalogami, vsebinami, organizacijo, didaktiko, metodiko,

- premalo razvedrilnih elementarnih didaktičnih gibalnih iger,

- brez podpore zgodbe, didaktičnih pripomočkov, glasbe,

- neupoštevanje principa: načrtovanje, organiziranje, izvajanje, evalviranje in motiviranje - spodbujanje. 


\section{Rutinski pristopi in postopki ter vsebine:}

- Dolgočasne vsebine - odsotnost inovacije pri izboru rekvizitov, pristopov, oblik in vsebin,

- izogibanje metodičnim načelom - lažje, težje; znano, neznano; enostavno, sestavljeno ...,

- opuščanje "zgodbe« v vadbeni enoti npr. pri otrocih odhod v »živalski vrt«, ki obsega uvodni, glavni in zaključni del zgodbe, $v$ kateri otroci oponašajo gibanje različnih živali,

- neupoštevanje logističnih pravil (racionalno organiziranje učencev iz ene oblike dela $v$ druge oblike; npr. $v$ uvodnem imamo tri skupine, $v$ glavnem delu štiri),

- skromna uporaba drobnih rekvizitov, orodij, opreme in drugih medijev, ki lahko prispevajo k kakovostnem programu kinezioloških ukrepov,

- suhoparne gimnastične in krepilne ter druge vaje in vsebine.

Komuniciranje in spodbujanje:

- Ukazovanje namesto vzpostavljanje sodelovalnega odnosa med otroki in vzgojiteljem,

- prepozno odzivanje ali sploh neodzivanje na ugotovljene slabosti v času izvedbe vadbene enote,

- hvaljenje osebnostnih lastnosti otroka, ne pa njegovega napredka,

- šibka, neprepričljiva, nesamozavestna, omahljiva komunikacija. 



\section{OBRAZLOŽITEV IZBRANIH NAJPOGOSTEJŠIH POJMOV V GIBALNEM POUČEVANJU}

Antropološka kineziologija - veda, ki preučuje gibanje človeka v interakciji z okoljem.

Aplikativna kineziologija - uporabna veda o gibanju $\vee$ medicini, športu, ergonomiji in kibernetiki itd.

Asociacija - stopnja gibalnega poučevanja, v kateri pride do združevanja spominskih informacij.

Avtomatizacija - stopnja gibalnega poučevanja, v kateri pride do samodejnega delovanja gibalnih vzorcev in procesov.

Prikaz gibanja - fizična predstavitev giba ali gibov oz. gibanja v procesu gibalnega poučevanja s ciljem, da učencu nazorno predstavimo, kaj od njega pričakujemo, da se nauči, in mu olajšamo izdelavo gibalnega načrta.

Didaktična načela - smernice za učinkovito poučevanje, kot npr.: učimo se od lažjega k težjemu, od znanega k neznanemu, od enostavnega k zapletenemu itd.

Didaktika na področju gibanja - preučevanje procesa usvajanja gibalnih znanj tako, da obravnavamo vsebino, metode in organizacijo gibalnega poučevanja.

Elementarne igre - gibalne igre s predznanju prilagojenimi pravili, ki otrokom omogočajo, da skozi igro razvijajo gibalne sposobnosti in kompetence ter se zabavajo, tekmujejo, raziskujejo ... 
Elementarni gibalni vzorci - preprosti gibalni vzorci, npr. hoja, tek, skok, met, potisk, plazenje, lazenje itd., ki se razvijejo $v$ otroštvu in so podlaga za razvoj nadaljnjih, kompleksnejših gibanj.

Faze gibalnega razvoja - refleksna, začetna, temeljna in športna/gibalna.

Faze učnega procesa - različne etape $v$ poučevanju, kot npr. posredovanje novih informacij, ponavljanje, utrjevanje, tekmovanje, preverjanje itd.

Gibalna zgodba - domišljijsko zasnovano besedno sporočilo vzgojitelja, s katerim otrokom osmisli gibanje, gibalne naloge in gibalne probleme, da jih lažje, raje in učinkoviteje rešujejo.

Gibalne kompetence - zmožnost posameznika, da na podlagi gibalnih sposobnosti, gibalnega znanja in motivacije učinkovito rešuje gibalne probleme skladno s pričakovanji okolja.

Gibalne sposobnosti - podedovane in od posameznika odvisne sposobnosti, ki določajo gibalne zmožnosti človeka, da učinkovito izvaja elementarne in sestavljene gibalne storitve. Opredeljujemo jih kot koordinacijo, ravnotežje, moč, gibljivost, natančnost, hitrost in vzdržljivost kot funkcionalno sposobnost.

Gibalni razvoj - kompleksen proces dinamičnih sprememb v gibalnem vedenju, zlasti v zgodnjem otroštvu (prehodnem stanju). Kažejo se v razvoju gibalnih sposobnosti, funkcionalne sposobnosti (vzdržljivosti) in gibalnih znanj.

Gibalni spomin - center v živčnem sistemu v bazalnih ganglijih in malih možganih, v katerem so shranjeni naučene gibalne informacije, vzorci, modeli, gibalni programi in strategije.

Gibalni stereotip - naučena kompleksna in strukturirana gibanja človeka, kot npr. plavanje, smučanje, kolesarjenje, nogomet itd.

Gibalni program -generaliziran program uskladiščen v spominu, ki se po potrebi dopolnjuje in prilagaja novim gibalnim problemom in izzivom.

Gibalni vzorec - za gibanje značilen vzorec, ki je odraz sistemske povezave v živčevju in se izraža v stereotipnih, ponavljajočih se oblikah gibanja, kot npr. hoja.

Gibalno poučevanje - kompleksna interakcija med učiteljem in učencem $\vee$ procesu gibalnega poučevanja, ki jo vodi učitelj, ter vključuje razlago, demon- 
stracijo in povratno informacijo s ciljem pridobivanja novih gibalnih informacij in usvajanja novih gibalnih znanj.

Gibalno učenje - osrednja hotena psihofizična dejavnost učenca v učnem procesu s ciljem pridobivanja novih gibalnih informacij in usvajanja novih gibalnih znanj.

Gibanje - telesna aktivnost, ki je posledica zavestnega krčenja skeletnih mišic in se odraža v večji porabi energije, kot je to značilno za mirovanje (1 MET). Pojem uporabljamo, ko opisujemo splošno gibanje človeka brez opredelitev vadbenih količin (intenzivnosti, trajanja, ponovitev, odmora).

Gibljivost - gibalna sposobnost, s katero dosegamo maksimalne obsege, amplitude gibov v sklepih posameznika.

Hitrost - gibalna sposobnost, s katero izvedemo gib z največjo frekvenco ali premagovanje ovir v najkrajšem času.

Individualizirani program - strukturirana dodatna pomoč in prilagoditve pri pouku, ki pri otrocih s posebnostmi v gibalnem razvoju lahko pripomorejo k učinkovitejšemu učenju in kakovostnejšemu življenju.

Inovativno gibalno poučevanje - ustvarjalno načrtovanje in uveljavljanje izboljšav pri gibalnem poučevanju, ki prispeva k učinkovitejšemu delu.

Kineziofobija - strah pred gibanjem, ki je praviloma neutemeljen.

Kineziologija - znanost o gibanju žive narave. V primeru, ko govorimo samo o človeku, je primerneje uporabljati pojem antropološka kineziologija.

Kompetence, delovne - zmožnost uporabe znanja, sposobnosti, osebnostnih lastnosti, izkušenj in motivacije, da na svojstven način učinkovito opravimo pričakovano delo ali vlogo.

Koordinacija - ključna gibalna sposobnost, ki nam omogoča učinkovito oblikovanje in izvajanje sestavljenih, zapletenih gibalnih nalog.

Medijski tekmovalni šport - specifičen sistem tekmovalnega športa s ciljem zabavati gledalce.

Menedžment športa - ravnanje s ključnimi viri, ki so pomembni za uresničevanje poslanstva in ciljev športne organizacije, prireditve ali športnika. 
Metodika gibalnega poučevanja - preizkušen specialni učni postopek, s katerim učencu posredujemo gibalno znanje.

Metodične enote - zaokroženi deli učne ure, kot npr. ogrevanje, glavni del, zakjjučni del itd.

Mikroraztrganine - poškodbe mišičnih vlaken kot posledica športne vadbe, ki spodbujajo proces obnovitve, okrepitve ter povečanje mišice.

Moč - sposobnost, pri kateri telo premaguje zunanje sile (sile gravitacije, vztrajnosti lastnega telesa ali predmetov, trenja, sile partnerja ali nasprotnika). Moč se pojavlja v treh oblikah: eksplozivni (hitrostno premagovanje zunanjih sil), repetetivni (ponavljajoče se premagovanje zunanjih sil) in statični (dolgotrajno napenjanje mišic).

Model gibalnega poučevanja - povezane faze gibalnega poučevanja, ki vsebujejo grobo izvedbo gibanja, usmerjeno razlikovanje, avtomatizacijo in modifikacijo.

Modifikacija - stopnja gibalnega poučevanja, v kateri pride do prilagajanja, dopolnjevanja in nadgrajevanja gibanja.

Motivacija - povzroča in usmerja naše delovanje kot notranji vzgib ali zunanja spodbuda, da nekaj storimo ali opustimo.

Motorika - veda, ki proučuje gibalne funkcije človeka.

Natančnost - gibalna sposobnost, ki omogoča natančno določitev smeri in intenzivnosti gibanja do želenega cilja tako, da se vodeni predmet privede do cilja ali da vrženi predmet zadene cilj.

Ponavljanje - večkratno ponavljanje novih gibalnih znanj s ciljem celostne usvojitve in avtomatizacije gibalnega znanja.

Poučevanje - poklicno in na trgu dela regulirano ukvarjanje s podajanjem učne snovi.

Preverjanje - primerjanje naučenih gibalnih znanj s postavljenimi cilji z namenom ugotavljanja in ocenitve napredka.

Priporočila primernega obsega gibanja - Svetovna zdravstvena organizacija otrokom priporoča uro zmernega gibanja dnevno. 
Proceduralni spomin - posebna vrsta spomina, ki omogoča, da znamo avtomatično izvajati že naučeno gibanje, ne da bi se zavestno spominjali potrebnih korakov, ki smo se jih naučili.

Ravnotežje - sposobnost ohranjanja stabilnega položaja s pomočjo hitrega oblikovanja kompenzacijskih gibov, ki so potrebni za ohranitev (statično ravnotežje) in za vračanje telesa iz porušenega (dinamično ravnotežje) $v$ ravnotežni položaj.

Razgibavanje, raztezanje - sklop specialnih telesnih vaj, ki naj bi povečale učinkovitost ter zmanjševale možnost poškodb in bolečin po športni vadbi, česar novejše raziskave ne potrjujejo $v$ celoti.

Sinapsa - stičišče med dvema živčnima celicama (nevronoma), kjer poteka sporočanje med posameznimi živčnimi celicami; učenje temelji na povečanju in krepitvi sinaps. Vsak nevron se lahko poveže z do 1.000 nevroni.

Stabilizacija - stopnja gibalnega poučevanja, v kateri pride do ustalitev, utrditev gibalnih programov.

Šport - človeška dejavnost v obliki posebno pogojenih gibanj s specifičnimi cilji razvedrila, zabave, vzgoje, tekmovanja, zaslužka ali kombinacije.

Športna kultura - družbena struktura razumevanja, vrednotenja in organiziranja gibalnih ter športnih vsebin in oblik.

Športna rekreacija - družbeni sistem prostovoljne gibalne dejavnosti s ciljem razvedrila, krepitve telesa in duha ter oddiha.

Športna vzgoja - celostni sistem gibalnega poučevanja in poučevanja s ciljem gibalnega in osebnostnega razvoja človeka.

Športne igre - strukturirana športna igra z natančno določenimi pravili, ki jih ne smemo spreminjati, cilj igre pa je zmaga.

Športni turizem - potovanje, ki posameznika spodbuja, da začasno zapusti svoje običajno okolje z namenom aktivnega sodelovanja v športu, ogleda športnih dogodkov ali obiska športno-turističnih znamenitosti.

Tekmovalni šport - strukturiran in na pravilih temelječ sistem gibalne aktivnosti s tekmovalnimi cilji in poudarkom na premagovanju tekmecev. 
Testiranje, merjenje, vrednotenje - sistematično, objektivno, primerljivo merjenje gibalnih sposobnosti in gibalnih znanj, običajno s tehničnimi pripomočki (meter, ura) in v ustreznih okoliščinah, z namenom pridobitve objektivnega vpogleda v napredek merjenca.

Trening - proces avtomatizacije naučenega gibanja in ustvarjanja nepredvidenih situacijskih razmer ter oteženih okoliščin s ciljem optimizacije gibanja.

Učenje - vsaka sprememba v vedenju, informiranosti, znanju, razumevanju, stališčih, spretnostih ali zmožnostih, ki je trajna in je ne moremo pripisati telesni rasti, zorenju ali razvoju podedovanih vedenjskih vzorcev.

Učitelj - kompetenten profesionalec, ki avtonomno in odgovorno usklajuje učne cilje, vsebino in tehnologijo s ciljem optimalnega poučevanja.

Učna priprava - administrativna dokumentacija priprave na pouk, opredeljena po času, vsebini, obliki in načinu in po kateri naj bi se uresničili cilji učnega procesa.

Učne metode - načini učinkovitega poučevanja, kot npr. analitična, sintetična, celostna, kombinirana, igralna, tekmovalna itd. metoda.

Učne oblike - preizkušeni načini učinkovitega organiziranja učencev in učnega procesa, kot npr. didaktična gibalna igra, štafetne in elementarne igre, poligon, vadba po igralnih postajah, prilagojena obhodna vadba, vadba $\vee$ parih, skupinah, individualna ter frontalna in kombinirana učna oblika.

Urjenje, utrjevanje, treniranje - dodajanje novih, težjih okoliščin za izvajanje že naučenih gibalnih znanj na podlagi ocen gibalnega statusa.

Vzdržljivost - funkcionalna sposobnost, ki omogoča izvajanje gibanja dlje časa in z nezmanjšano učinkovitostjo. 


\section{POVZETEK}

Današnji razvoj tehnologije spreminja družbo ter posredno tudi učne strategije in postopke. Svet je postal drugačen: zahteva inovativnost, prilagodljivost, učinkovitost in hitro odzivnost. Načini reševanja novih pričakovanj, tudi na področju poučevanja, se razlikujejo od pristopov, ki bi jih morda uporabili pred desetletjem, pa čeprav izobraževanje velja za konservativno in počasi odzivno dejavnost. Spreminja se tudi sam proces sprememb in vključevanje novosti v gibalno poučevanje postaja vsakodnevni pomemben izziv za učitelja/vzgojitelja. Danes sta bolj kot kadarkoli pomembni vloga in naloga vzgojitelja, da gibalno usposobi in otroke že v zgodnjem otroštvu ozavesti o pomenu, koristih in prednostih gibanja $v$ zdravem okolju. Za učinkovito poučevanje pa vzgojitelj potrebuje primerno splošno in specialno znanje, sposobnosti in motivacijo, da je lahko kompetenten pri izpolnjevanju delovnih nalog in poslanstva poučevanja. Zato je ključni namen knjige predstaviti izbrana poglavja s področja antropološke kineziologije, ki bodo lahko prispevala k širitvi in poglobitvi znanja o zgodnjem gibalnem poučevanju.

$\checkmark$ prvem delu je poudarek na prepoznavanju značilnosti gibalnega razvoja otroka, ker je $v$ tem obdobju otrok najbolj izpostavljen številnim tako pozitivnim kot negativnim vplivom okolja. Samo s skrbno načrtovanimi in izvedenimi gibalnimi dejavnostmi lahko optimalno razvijemo otrokove podedovane gibalne in funkcionalne sposobnosti. V nadaljevanju besedila predstavljamo zakonitosti otrokovega gibalnega razvoja, od procesa opuščanja refleksnih ter pričetka rabe spontanih ritmičnih ter hotenih gibov pa vse do razvoja osnovnih ter kompleksnih gibalnih vzorcev. Pri tem gibalni prostor pojasnjujemo z 
modelom med seboj povezanih gibalnih sposobnosti. Ker so razlike v izvedbi gibov in gibanja nasploh, tako v kakovosti kot količini, odvisne prav od razvoja in vzdrževanja gibalnih sposobnosti, jim namenjamo posebno pozornost. Gibalne sposobnosti namreč najbolj vplivajo na otrokove gibalne dosežke in uspešnost pri reševanju gibalnih izzivov. Uvodoma pojasnimo značilnosti ravnotežja kot sposobnosti hitrega oblikovanja nadomestnih gibov, ki so potrebni za ohranjanje ali vračanje telesa v ravnotežni položaj, ko je ta porušen. Predstavimo metode razvoja ravnotežja, temelječe na rušenju ravnotežja z rotacijo, zmanjševanjem podporne ploskve in odvzemom vida, ter merske postopke za ugotavljanje ravnotežja. Nadaljujemo z najkompleksnejšo gibalno sposobnostjo: koordinacijo, ki je odgovorna za učinkovito oblikovanje in izvajanje sestavljenih gibalnih nalog in jo prepoznamo po pravilni, pravočasni, gospodarni, stabilni ter izvirni izvedbi gibanja. Posebno pozornost namenjamo opisu dejavnikov, od katerih je odvisna, in sicer pojasnimo sistem za sprejem in analizo podatkov iz okolja in telesa, opišemo center za gibalni spomin, v katerem so shranjeni gibalni vzorci, ter predstavimo delovanje kortikalnega in subkortikalnega centra za oblikovanje gibanja. $V$ naslednjem poglavju se posvečamo razlagi vloge in pomena gibljivosti kot sposobnosti, ki je odgovorna za izvedbo gibov z največjim možnim razponom. Predstavimo notranje in zunanje dejavnike, ki vplivajo nanjo, ter poudarimo rabo izključno dinamičnih oblik razvoja gibljivosti pri najmlajših otrocih. Nadaljujemo z opisom moči, ki jo opredeljujemo kot sposobnost učinkovitega opravljanja dela v enoti časa na način pretvarjanja kemične energije v skeletnih mišicah v mehansko energijo. Izpostavimo pomen funkcionalnih dejavnikov moči, kot so učinkovita dejavnost gibalnih centrov v centralnem živčnem sistemu, ki vzdražijo delovanje mišičnih vlaken, prevodnost živčnih poti, po katerih potujejo impulzi do ciljnih mišic, propustnost sinaps in kakovost biokemičnih procesov, ki omogočajo pretvorbo energije. Predstavimo še hitrost, ki jo opredeljujemo kot sposobnost izvedbe gibanja v najkrajšem možnem času, in pojasnjujemo predvsem njeno pogojenost z dednim zapisom in razmerjem $v$ strukturi hitrih ter počasnih mišičnih vlaknih. Temu sledi še razlaga zadnje gibalne sposobnosti: natančnosti. Opredelimo jo kot sposobnost primerne določitve ustrezne smeri in sile za usmeritev bodisi telesa ali predmeta v želeni cilj. Omenimo še funkcionalno sposobnost vzdržljivost, ki temelji na učinkovitem delovanju tako srčno-žilnega kot dihalnega sistema.

Drugi del namenjamo razlagi in primerom zgodnjega gibalnega učenja in poučevanja. Pri tem zgodnje gibalno učenje razumemo kot psihomotorični učni proces, s katerim hoteno in trajno spremenimo zmogljivost oblikovanja gibalnih vzorcev s pomočjo strukturirane ali nestrukturirane gibalne igre, 
ki ji kasneje postopno sledi gibalna vadba, poučevanje pa razlagamo kot kompleksno interakcijo med učencem in učiteljem $v$ procesu gibalnega poučevanja s ciljem usvajanja novih gibalnih znanj - učnih izidov. Najprej pojasnimo nevrološke osnove delovanja gibalnega sistema, ki omogočajo gibalno učenje. Opredelimo tri med seboj povezane ključne faze gibalnega učnega procesa: opazovanje in načrtovanje gibanja, analizo gibanja in vadbo gibanja, ki znova izzove potrebo po ponovnem opazovanju. Posebno pozornost namenjamo motivacijskim dejavnikom, saj ni dovolj otroke samo pritegniti k gibalnemu učenju, ampak je treba tudi dlje obdržati trajanje njihove pozornosti. Pri gibalnem učenju gre namreč izključno za izvajanje številnih kakovostnih ponovitev, ki se avtomatizirajo in shranijo v gibalni spomin. Pri ponavljanju je pomemben motivacijski dejavnik tudi tekmovanje, pri čemer se zavzemamo za čim kasnejše razvrščanje: prvi, drugi, tretji, zadnji! Poudarjamo, da naj bo v zgodnjem otroštvu v ospredju tekmovanje s samim seboj in primerjanje z drugimi, ne pa samo ali predvsem premagovanje.

Vzgojitelj pri svojem delu potrebuje učinkovit model komuniciranja z otroki, ki temelji na verbalni in neverbalni obliki in ga odlikujejo direktnost, osebni pristop, korektnost, etičnost, jasnost, osredotočenost na eno samo stvar in preverjanje razumljenosti sporočila. Samo kakovostno komuniciranje prispeva k varni izvedbi gibalnega poučevanja. Posebej poudarjamo še vlogo in pomen učinkovitega prikaza - demonstracije v prvi fazi gibalnega poučevanja, saj učencu omogoča, da miselno ustvari svojo lastno shemo, gibalni načrt, ki ga uporabi, ko poskuša videno gibanje sam ponoviti s svojim telesom in umom. Določen del preučevanja smo namenili še pojasnjevanju pojma pouka in poučevanja, kjer smo poudarili, da je didaktika lahko most med teorijo in prakso, ki povezuje virtualno s povsem konkretnim. Predstavili smo najpogostejša didaktična načela, pomembne učne oblike ter učne metode. Poglobljeno smo obravnavali igro in zgodbo kot najpomembnejše sredstvo zgodnjega gibalnega poučevanja. Še posebej smo obravnavali didaktično gibalno igro ter elementarne gibalne igre, ki so sploh najpogostejša izbira vzgojiteljev pri delu z otroki.

$\checkmark$ poglavju o vrednotenju smo poudarili, da je za načrtovanje ustreznega učnega procesa pomembno uporabljati teste, meritve in ocenjevanje ter pridobljene izide uporabiti kot kazalnike uspešnosti poučevanja. Preučili smo tudi najpogostejše primere slabe pedagoške prakse in tako opozorili na tisto, na kar moramo pri našem delu še posebej paziti. Večjo pozornost smo namenili še zagotavljanju varnosti pri gibalnem poučevanju in podrobno pojasnili pojem športne nesreče, kako ocenjevati tveganje zanjo ter kako preprečevati poškodbe. Dotaknili smo se tudi vseživljenjskega gibalnega učenja, ki zaje- 
ma tudi vse oblike poučevanja, od formalnega, aformalnega - priložnostnega do povsem neformalnega. V poglavju o menedžmentu gibalnega razvoja obravnavamo predvsem proces usklajevanja ključnih dejavnikov, ki omogočajo učinkovito uresničevanje ciljev načrtovanja, organiziranja, izvajanja in vrednotenja gibalnega poučevanja. Kakovosten menedžment prepoznamo po tem, da sta učni cilj lahko že izbrani učna vsebina in oblika.

Z zbranimi smernicami za to, kako kakovostno in učinkovito obravnavati otroke na področju gibalnega poučevanja, da bodo lahko na všečen in zdravju prijazen način usvajali elementarne in zapletene gibalne vzorce, smo na preprost način povzeli ključna izhodišča učne strategije. $V$ poglavju o inovativnem gibalnem poučevanju med drugim predstavljamo tudi avtorski model $4 \mathrm{P}, \mathrm{ki}$ temelji na naslednjih štirih fazah: povpraševanje in pričakovanje učencev; prilagajanje in poenostavljanje; ponudba in podpora ter pomoč.

Knjigo smo zaključili z obrazložitvijo izbranih najpogostejših pojmov, ki jih uporabljamo pri gibalnem poučevanju, s čimer smiselno povežemo vsebine in oblike preučevanja učinkovitih pristopov in postopkov zgodnjega gibalnega poučevanja. Pri tem je cilj osvežitev ter poglobitev kompetenc vzgojiteljev in učiteljev na kineziološkem področju. 


\section{SUMMARY}

Modern technological development is changing our society - and indirectly also the teaching strategies and methods. The world has indeed changed: it demands innovativeness, adaptability, effectiveness and high responsiveness. The methods of addressing new expectations, also in teaching, differ from the approaches that might have been used a decade ago, and this despite the fact that education is regarded as a conservative, slow-to-respond sphere of activity. The process of change itself is undergoing changes, and the introduction of innovations into the teaching of motor skills is becoming a major day-today challenge faced by school/preschool teachers. Today, more than ever before, preschool teachers have an important role and function to help children develop motor skills early on in their childhood and to raise their awareness of the importance, benefits and advantages of physical activity in a healthy environment. In order to ensure effective teaching, however, preschool teachers need to possess suitable general and specialized knowledge, abilities and motivation to be fully competent in fulfilling the duties and mission of teaching. This is why the book's principal aim is to examine and present select chapters from the field of anthropological kinesiology that may help broaden and deepen the knowledge applicable to the teaching of motor skills in early childhood.

The first part of the book focuses on identifying the characteristics of motor development in children, since at this stage of life children are the most exposed to numerous external influences, both positive and negative. It is only with carefully planned and implemented movement activities that we can 
optimally develop a child's hereditary motor and functional abilities. Further chapters cover the inherent principles of children's motor development, from the process of substituting reflex movements for spontaneous rhythmic and voluntary movements, all the way to developing basic and complex movement patterns. In this context, the range of movement is explained using a model of interconnected motor skills. Since the differences in the performance of individual movements and movement in general, both in terms of quality and quantity, notably depend on the development and maintenance of motor skills, a special focus is placed on motor skills. It is motor skills that have the greatest impact on a child's motor achievements and success in overcoming movement challenges. The introduction explains the characteristics of balance as the ability of rapidly forming substitution movements needed for maintaining or restoring a balanced position of the body when balance is lost. Also presented are methods of developing balance based on disrupting balance through rotation, reducing the size of the base of support, and blindfolding, along with techniques for measuring balance. The next topic examined is the most complex motor skill, coordination, which is responsible for the effective formation and execution of compound motor tasks and is recognizable by the correct, well-timed, efficient, stable and original performance of movement. Special attention is focused on describing the factors that affect coordination - comprising an explanation of the system for receiving and analyzing data from the environment and the body, a description of the motor memory centre, which stores movement patterns, and a presentation of how the cortical and subcortical centres for movement formation work. The next chapter looks at the role and importance of flexibility as the ability responsible for performing movements in the widest possible range. Internal and external factors impacting flexibility are presented, underscoring the use of exclusively dynamic methods for developing flexibility in youngest children. Next up is the description of strength, which is defined as the ability of effectively doing work per unit of time whereby chemical energy inside skeletal muscles is converted into mechanical energy. The importance of functional factors of strength is put into focus, such as effective activity of motor centres in the central nervous system, which call muscle fibres into action, conduction of nervous pathways along which impulses reach the target muscles, the importance of synaptic transmission, and the quality of biochemical processes that facilitate the conversion of energy. The next motor skill presented is speed, which is defined as the ability to execute a movement as quickly as possible. This section primarily deals with speed and its link to genetic information and structural proportion of fast- to slow-twitch muscle fibres. This is followed 
by an examination of the last of the motor skills, accuracy, which is defined as the ability to properly determine the right direction and force for directing the body or an object towards the desired target. Also briefly examined is endurance, a functional skill which relies on the efficient functioning of the cardiovascular and respiratory systems.

The second part of the book provides explanations and examples of motor learning and motor teaching in early childhood. In this context, motor learning in early childhood is understood as a psychomotor learning process whereby one voluntarily and permanently changes one's ability of forming movement patterns through motor play, either structured or unstructured, which is later gradually followed by motor practice. Motor teaching, on the other hand, is defined as a complex interaction between student and teacher in the process of motor teaching, with the aim of acquiring new motor skilIs - learning outcomes. The first section looks at the neurological bases behind the functioning of the motor system which facilitate motor learning. This is followed by a definition of three interconnected key stages of the motor learning process: observation and planning of movement, movement analysis, and practice of movement, which again provokes the need for repeated observation. A special focus is placed on motivational factors, since merely engaging children to take part in motor learning is not enough - teachers have to help them maintain a longer attention span. The fact is that motor learning is all about properly performing numerous repetitions, which become automated and get stored in the motor memory. In the context of repetition, competition is an important motivational factor, where, as we see it, it is best to introduce the ranking of children into first, second, third, and last place as late in the learning process as possible. It is underlined that in early childhood children should focus on competing against themselves and comparing to others, not only or mainly on defeating others.

In their work, preschool teachers need an effective model of communication with children, one that is based on verbal and nonverbal modes of communication and characterized by directness, personal approach, equal treatment, ethical conduct, clarity, focusing on one thing at a time and making sure the message is properly understood. Quality communication alone is what contributes to the safety of motor teaching. Particularly significant are the role and importance of effective practical demonstration during the first stage of motor teaching, since it allows students to visualize their own scheme, or movement plan, which they later follow when trying to repeat the observed movement with their own bodies and minds. A large part of our study also focuses on explaining the concepts of lesson and teaching, highlighting that didactics 
may well be a bridge between theory and practice, a link between the virtual and the completely real worlds. The book provides an overview of the most common didactic principles, important teaching techniques, and teaching methods. Examined in detail are play and story as the most important components of motor teaching in early childhood. Didactic motor play and elementary motor games, generally the most common choice of preschool teachers when working with children, are discussed in greater depth.

The chapter on evaluation underlines that it is important to use tests, measurements and marking when planning a suitable teaching process and to use the obtained outcomes as indicators of teaching success. Also included is a review of the most common examples of poor pedagogical practices, the aim of which is to highlight the aspects teachers should be particularly careful about in their work. A major focus is also placed on the topic of ensuring safety in motor teaching, which includes a detailed explanation of the term sporting accident and a look at how to assess the risk of sporting accidents and how to prevent injuries. Also briefly discussed is the topic of lifelong motor learning, which involves all the approaches to teaching as well - from formal, informal/incidental, to entirely nonformal. The chapter on the management of motor development mainly discusses the process of coordinating the key factors that allow for an effective fulfilment of the goals and objectives in terms of planning, organization, implementation and evaluation of motor teaching. Quality management can be recognized by having already selected teaching subjects and techniques which can directly serve as a teaching goal.

To provide a simple summary of the teaching strategy's key starting points, the book also presents a collection of guidelines on how to provide children with quality, effective treatment in the area of motor teaching in order to enable them to learn elementary and complex movement patterns in an enjoyable and healthy way. The chapter on innovative motor teaching presents, among other things, a copyrighted $4 \mathrm{P}$ model, which comprises four stages: demand and expectation among students; adaptation and simplification; supply, and help and support.

The final section of the book provides explanations of a selection of terms the most commonly used in motor teaching, thereby drawing a meaningful connection between the substance and methods of studying effective approaches and techniques for motor teaching in early childhood and the aim of refreshing and deepening the competences of preschool/school teachers in the field of kinesiology. 


\section{LITERATURA}

Bahovec, E. (2001). Kurikulum za vrtce: predšolska vzgoja v vrtcih. Ljubljana, Slovenija: Ministrstvo za šolstvo in šport.

Bartoluci, M. (1997). Ekonomika in menedžment sporta. Zagreb, Hrvaška: Fakultet za fizičku kulturu sveučilišta u Zagrebu.

Boekaerts, M. (2013). Motivacija in čustva imajo ključno vlogo pri učenju. V H. Dumont, D. Istance in F. Benavides (ur.), O naravi učenja: uporaba raziskav za navdih prakse (str. 83-102). Ljubljana, Slovenija: Zavod Republike Slovenije za šolstvo.

Cemič, A. (1997). Motorika predšolskega otroka. Ljubljana, Slovenija: Dr. Mapet igre, igrače in učila, d. o. o.

Chelladurai, P. (1994). Sport Management: Defining the Field. European Journal for Sport Management, 1, 7-21.

Cockerham, W. C. (2005). Health lifestyle theory and the convergence of agency and structure. Journal of Health and Social Behavior, 46(1), 51-67.

Daft, R. L. (2003). Management. Mason, OH: Thomson South-Western West.

Duerden, E. G., in Laverdure-Dupon, D. (2008). Practise makes cortex. The Journal of Neuroscience, 28(35), 8655-8657.

Dumont, H., Istance, D., in Benavides, F. (2010). The nature of learning: Using research to inspire practice. Pariz, Francija: OECD Publishing.

Eckert, H. (1987). Motor development. Indianapolis, IN: Benchmark Press. 
Edwards, W. H. (2010). Motor learning and control: From theory to practice. Belmont, CA: Wadsworth Cengage Learning.

Epstein, D. (2015). Športni gen: talent, trening in resnica o uspehu. Ljubljana, Slovenija: UMco.

Ericsson, K. A. (2006). The Cambridge handbook of expertise and expert performance. Cambridge, Anglija: Cambridge University Press.

Gabrijelčič Blenkuš, M. (2013). Prekomerna prehranjenost in debelost pri otrocih in mladostnikih v Sloveniji (Gradivo za Odbor DZ RS za zdravstvo). Ljubljana, Slovenija: Inštitut za varovanje zdravja.

Gallahue, D. L., Ozmun, J. C., in Goodway, J. D. (2011). Motor development: Infants, children, adolescents, adults. Boston, MA: McGraw-Hill.

Gill, Diane L. (2000). Psychological dynamics of sport and exercise. Champaign, IL: Human Kinetics.

Gopnik, A., Meltzoff, A. N., in Kuhl, P. K. (2001). The scientist in the crib: What early learning tells us about the mind. New York, NY: Perennial.

Graham, G. (2001). Teaching children physical education: Decoming a master teacher. Champaign, IL: Human Kinetics.

Grey-Thompson, T., Huppert, J., Keeley, B., in Leslie, C. (2014). Tackling physical inactivity - A coordinated approach. Pridobljeno s https://parliamentarycommissiononphysicalactivity.files.wordpress.com/2014/o4/apcopa-final.pdf

Harrington, G. (2005). Fundamental motor skills (Raziskovalno poročilo). Tasmanija, Avstralija: Deputy Secretary (Education), Department of Education, Community and Cultural Development.

Haywood, K., Robertson, M. A., in Getchell, N. (2012). Advanced analysis of motor development. Champaign, IL: Human Kinetics.

Henderson S. E., Sugden, D. A., in Barnett, A. L. (2014). Baterije za oceno otrokovega gibanja: Priročnik za izvajalce ABC gibanja (Druga izdaja). Ljubljana, Slovenija: Center za psihodiagnostična sredstva.

Houlihan, B. (2008). Sport and society. London, Slovenija: SAGE Publications.

Jelenc, Z. (2007). Strategija vseživljenjskosti učenja v Sloveniji. Ljubljana, Slovenija: Ministrstvo za šolstvo in šport Republike Slovenije; Pedagoški inštitut.

Jeriček Klanšček, H., Koprivnikar, H., Drev, A., Pucelj, V., Zupanič, T., in Britovšek, K. (2015). Z zdravjem povezana vedenja $v$ šolskem obdobju med mladostniki v Sloveni- 
ji (Izsledki mednarodne raziskave HBSC, 2014). Ljubljana, Slovenija: Nacionalni inštitut za javno zdravje.

Kohont, A. (2005). Kompetenčni profili slovenskih strokovnjakov za upravljanje človeških virov (Magistrsko delo). Univerza v Ljubljani, Fakulteta za družbene vede, Ljubljana.

Kremžar, B., in Petelin, M. (2001). Otrokovo gibalno vedenje. Ljubljana, Slovenija: Društvo za motopedagogiko in psihomotoriko.

Labinowicz, E. (2010). Izvirni Piaget: mišljenje - učenje - poučevanje. Ljubljana, Slovenija: DZS.

Laval, C. (2005). Šola ni podjetje: neoliberalni napad na javno šolstvo. Ljubljana, Slovenija: Krtina.

Lussier, R., in Kimball, D. (2004). Sport management: Principals, applicationas, skill development. Mason City, IA:Thompson Learning.

Malina, R. M., Bouchard, C., in Bar, O. (2004). Growth, maturation, and physical activity. Champaign, IL: Human Kinetics.

Marentič Požarnik, B. (2019). Psihologija učenja in pouka: od poučevanja do učenja. Ljubljana, Slovenija: DZS.

Marinšek, M., in Rajtmajer, D. (2017). Šport v funkciji doživljajske vzgoje. Ljubljana, Slovenija: Amalietti \& Amalietti.

Marjanovič Umek, L., in Zupančič, M. (2004). Razvojna psihologija. Ljubljana, Slovenija: Znanstvenoraziskovalni inštitut Filozofske fakultete.

Martens, R. (1997). Successful coaching. Champaign, IL: Human Kinetics.

Medved Udovič, V., Cotič, M., in Cenčič, M. (ur.) (2008). Sodobne strategije poučevanja in poučevanja. Koper, Slovenija: Univerza na Primorskem, Pedagoška fakulteta.

Musek, J., in Pečjak,V. (2001). Psihologija. Ljubljana, Slovenija: Educy.

Nemec, B., in Krajnc, M. (2011). Razvoj in učenje predšolskega otroka. Ljubljana, Slovenija: Grafenauer založba, d. o. o.

Novak, D., Kovač, M., in Čuk, I. (2008). Gimnastična abeceda. Ljubljana, Slovenija: Univerza v Ljubljani, Fakulteta za šport.

OECD (2013). Innovative learning environment. Pariz, Francija: OECD Publishing. 
Pangrazi, R. P. (2000). Dynamic physical education for elementary school children. Boston, MA: Allyn in Bacon.

Parks, J., in Qurterman, J. (2002). Contemporary sport management. Champaign, IL: Human Kinetics.

Pistotnik, B. (2004). Vedno z igro: elementarne in družabne igre za delo in prosti čas. Ljubljana, Slovenija: Fakulteta za šport, Inštitut za šport.

Pistotnik, B. (2011). Osnove gibanja v športu. Ljubljana, Slovenija: Fakulteta za šport, Inštitut za šport.

Pistotnik, B., Pinter, S., in Dolenec, M. (2002). Gibalna abeceda. Ljubljana, Slovenija: Fakulteta za šport, Inštitut za šport.

Pišot, R. (2012). Lifelong competency model of motor development. Kinesiologia Slovenica, 18(3), 35-46.

Pišot, R., in Planinšec J. (2010). Struktura motorike v zgodnjem otroštvu: gibalne sposobnosti v zgodnjem otroštvu v interakciji z ostalimi dimenzijami psihosomatičnega statusa otroka. Koper, Slovenija: Univerza na Primorskem.

Plevnik, M. (2014). Dejavniki izvedbe elementarnega gibalnega vzorca plezanja v zgodnjem otroštvu (Doktorsko delo). Univerza na Primorskem, Fakulteta za matematiko, naravoslovje in informacijsko tehnologijo, Koper.

Rajtmajer, D. (1991). Metodika telesne vzgoje: predšolska vzgoja - II. knjiga. Maribor, Slovenija: Univerza v Mariboru, Pedagoška fakulteta.

Rajtmajer, D. (1997). Diagnostično-prognostična vloga norm nekaterih motoričnih sposobnosti pri mlajših otrocih: tretja faza informacijskega sistema za spremljanje in vrednotenje motoričnih sposobnosti mlajših otrok. Maribor, Slovenija: Pedagoška fakulteta.

Retar, I. (2014). Športni menedžment in gibalna kompetentnost otrok. V R. Pišot idr. (ur.), Kineziologija - pot zdravja; zbornik prispevkov mednarodne conference Otrok v gibanju (str. 403-412). Koper, Slovenija: Univerza na Primorskem, Znanstveno-raziskovalno središče, Univerzitetna založba Annales.

Retar, I. (2015). Inovativni didaktični pristopi na organizacijskem področju športa v šoli.V N. Pegan, Nika, U. Čeklić in T. Volmut (ur.), Izmerimo in razgibajmo uro športa v šoli (str. 79-85). Koper, Slovenija: Založba Univerze na Primorskem.

Retar, I. (2017). Inovacije v gibalnem poučevanju v zgodnjem otroštvu. V Plenary lectures, invited proceedings, book of abstracts and book of proceedings 4 th Inter- 
national Scientific Congres (str. 84-89). Portorož, Slovenija: Slovenian Gymnastics Federation.

Retar, I., in Lepičnik Vodopivec, J. (2017). Kompetentnost vzgojiteljev za inovativno gibalno poučevanje. Pedagoška obzorja, 32(1), 17-32.

Retar, I., Pišot, R., in Jelovčan, G. (2016). Gibalne športne aktivnosti otrok v zgodnjem otroštvu: priročnik za študente (predšolska vzgoja). Koper, Slovenija: Univerza na Primorskem, Pedagoška fakulteta.

Retar, I., Plevnik, M., in Kolar, E. (2013). Key competences of Slovenian sport managers. Annales Kinesiologiae, 4(2), 81-94.

Retar, I., Štemberger, T., in Lepičnik-Vodopivec, J. (2018). Matrika inovativnega zgodnjega gibalnega poučevanja. VT. Štemberger idr. (ur.), Oblikovanje inovativnih učnih okolij = Constructing innovative learning environments (str. 253-265). Koper, Slovenija: Založba Univerze na Primorskem.

Retar, I., Plevnik, M., Hozjan, D., in Kolar, E. (2014). Ustvarjalno vseživljenjsko učenje na področju menedžmenta v športu. V D. Hozjan (ur.), Izobraževanje za 21. stoletje - ustvarjalnost v vzgoji in izobraževanju (str. 421-438). Koper, Slovenija: Univerza na Primorskem, Znanstveno-raziskovalno središče, Univerzitetna založba Annales.

Samardžija Pavletič, M., Retar, I., Atiković, A., in Kolar, E. (2014). The role of a sports manager in reducing the incidence of sports injuries among adolescents in gymnastics. V R. Pišot idr. (ur.), Kineziologija - pot zdravja: zbornik prispevkov (str. 213-222). Koper, Slovenija: Univerza na Primorskem, Znanstveno-raziskovalno središče, Univerzitetna založba Annales.

Sheridan, M. D., Sharma, A., in Cockerill, H. (2008). From birth to five years: Children's developmental process (3th ed.). London, Anglija; New York, NY: Routledge. Starc, G., Strel, J., Kovač, M., Leskošek, B., in Jurak, G. (2015). SLOfit 2015 - analiza telesnega in gibalnega razvoja otrok in mladine slovenskih osnovnih in srednjih šol $\mathrm{V}$ šolskem letu 2014/2015. Ljubljana, Slovenija: Fakulteta za šport.

Statistični urad Republike Slovenije (2016). Pridobljeno s http://pxweb.stat.si/pxweb/Dialog/Saveshow.asp

Stodden, D. F., Goodway, J. D., Langendorfer, S. J., Roberton, M. A., Rudisill, M. E., Garcia, C., in Garcia, L. E. (2008). A developmental perspective on the role of motor skill competence in physical activity: An emergent relationship. Quest, 60(2), 290-306. 
Strel, J., in Šturm, J. (1981). Zanesljivost in struktura nekaterih motoričnih sposobnosti in morfoloških značilnosti šestinpolletnih učencev in učenk. Ljubljana, Slovenija: Inštitut za kineziologijo, Fakulteta za telesno kulturo.

Strmčnik, F. (2001). Didaktika: osrednje teoretične dileme. Ljubljana, Slovenija: Znanstveni inštitut Filozofske fakultete.

Svetlik, l., in Pavlin, S. (2004). Izobraževanje in raziskovanje za družbo znanja: demokratizacija, profesionalizacija in odpiranje v svet. Teorija in praksa, 41(1/29), 199-211.

Škof, B. (2017). Šport po meri otrok in mladostnikov. Ljubljana, Slovenija: Univerza v Ljubljani, Fakulteta za šport.

Štiblar-Martinčič, D., Cör, A., Cvetko, E., Marš, T., in Legan, M. (2008). Anatomija, histologija in fiziologija. Ljubljana, Slovenija: Medicinska fakulteta Univerze v Ljubljani; Maribor, Slovenija: Medicinska fakulteta Univereze v Mariboru; Izola, Slovenija: Fakulteta za vede o zdravju Univerze na Primorskem.

Štrucl, M. (1999). Fiziologija živčevja. Ljubljana, Slovenija: Medicinski razgledi.

Tancig, S. (1996). Razlage psihologije gibalnega poučevanja: teorija gibalnega programa, teorija sheme in neopiagetova teorija. Psihološka obzorja, 5(4), 105-116.

Tanner, J. M. (1978). Foetus into man: Physical growth form conception to maturity. London, Anglija: Open Books.

Thorndike, E. (1908). The effect of practice in the case of a purely intellectual function. American Journal of Psyhology, 19(3), 374-384.

Ušaj, A. (2003). Kratek pregled osnov športnega treniranja. Ljubljana, Slovenija: Fakulteta za šport.

Videmšek, M., in Cemič, A. (1991). Analiza in primerjava dveh različnih modelov obravnavanja motoričnih sposobnosti pet in pol letnih otrok (Magistrska naloga). Univerza v Ljubljani, Fakulteta za šport, Ljubljana.

Videmšek, M., in Jovan N. (2002). Čarobni svet igral in športnih pripomočkov. Ljubljana, Slovenija: Fakulteta za šport, Inštitut za šport.

Videmšek, M., in Pišot, R. (2007). Šport za najmlajše. Ljubljana, Slovenija: Univerza v Ljubljani, Fakulteta za šport, Inštitut za šport.

Videmšek, M., in Visinski, M. (2011). Športne dejavnosti predšolskih otrok. Ljubljana, Slovenija: Univerza v Ljubljani, Fakulteta za šport, Inštitut za šport in Zavod za šport Republike Slovenije. 
Videmšek, M., Strah, N., in Stančevič, B. (2001). Igrajmo se skupaj: program športnih dejavnosti za otroke in starše. Ljubljana, Slovenija: Fakulteta za šport, Inštitut za šport.

Walkley, J., Armstrong, D., in Clohesy, P. (1998). Fundamental motor skills: An activities resource for classroom teachers. Melbourne, Avstralija: Department of Education Victoria.

WHO (2011). Global recomandations on physical activity for health. Pridobljeno s http://www.who.int/dietphysicalactivity/leaflet-physical-activity-recommendations.pdf

White, A. (2009). From comfort zone to performance management. Belgija: White \& MacLean Publishing.

Završnik, J., in Pišot R. (2005). Gibalna/športna dejavnost za zdravje otrok in mladostnikov. Koper, Slovenija: Univerza na Primorskem, Znanstveno-raziskovalno središče, Založba Annales. 



\section{RECENZIJI}

Delo doc. dr. Iztoka Retarja obravnava temo poučevanja gibalnih aktivnosti v zgodnjem otroštvu. V svetu, ki ga zaznamujeta hiter tempo in pretežno sedentarni način življenja, je obravnavana tema še kako pomembna. Pomen zadostnega in primernega gibanja, predvsem v zgodnjem obdobju otroštva, so prepoznali številni učenjaki in strokovnjaki, ki se ukvarjajo s preučevanjem gibalnega vedênja. Rastoče število znanstvenih spoznanj v zadnjem desetletju zato ni presenetljivo in priča o aktualnosti tematike, ki jo obravnava monografija.

Avtorjeva teza o potrebnih spremembah v poučevanju gibanja, kot enem izmed načinov reševanja novih pričakovanj v sodobnem svetu, je privlačna in bo $v$ ljudeh, ki jim je mar za primeren gibalni razvoj otrok, zagotovo vzbudila zanimanje za branje.

Monografijo sestavljajo štirje med seboj povezani vsebinski sklopi, in sicer: gibalni nadzor, gibalni razvoj, učenje gibanja in delovne kompetence vzgojiteljev. Na njihovi podlagi s pomočjo lastnih raziskovalnih spoznanj in obsežnega pregleda druge literature izpelje avtorski model poučevanja gibanja, ki ga poimenuje model inovativnega gibalnega poučevanja.

Uvajanje priporočil iz modela lahko prispeva $\mathrm{h}$ kakovostnejšemu in $\mathrm{k}$ učinkovitejšemu delu vzgojiteljev, učiteljev in učencev na gibalno-športnem področju. Predvsem zaradi izpostavljanja kreativnosti v modelu inovativnega gi- 
balnega poučevanja pa ga lahko razumemo tudi kot izhodišče za profesionalni razvoj vseh s poučevanjem povezanih poklicev.

Monografija nedvomno prispeva k širjenju in poglabljanju znanja na področju poučevanja gibalnih aktivnosti in ima poleg znanstvene pomembno izobraževalno vrednost. Kljub temu, da avtor v predgovoru posebej nagovarja vzgojitelje, jo priporočam tudi učiteljem, športnim pedagogom, kineziologom, študentom pedagoških študijskih smeri in širši javnosti, ki jo zanimajo učinki usmerjenih dejavnosti na gibalni razvoj otrok.

Miha Marinšek

II

Rad doc. dr. sc. Iztoka Retarja Zgodnje gibalno učenje in poučevanje koncipiranje zanimljivo i privlačno. Svako poglavlje sadrži više podnaslova koji bi sve one koji rade s djecom, prvenstveno studente, odgojitelje i učitelje, trebali uputiti u primjenu određenih spoznaja opisanih u priručniku. Autor se u priručniku bavi problemom poučavanja motoričkih aktivnosti za djecu predškolske i školske dobi koje su izuzetno važne u suvremenoj kineziologiji, kako s teorijskog tako i s praktičnog aspekta. Ovim priručnikom autor je približio studentima, odgojiteljima i učiteljima spoznaje o važnosti ranog i adekvatnog provođenja motoričkih aktivnosti jer im njihovo razumijevanje u svakodnevnom radu s djecom može pomoći da svoj odgojno-obrazovni rad učine učinkovitijim.

Autor u radu objašnjava ulogu i važnost ranog učenja motoričkih aktivnosti, osnovne teorije integriranog razvoja djeteta, faze motoričkog razvoja djece s naglaskom na ulogu i značaj biotičkih motoričkih znanja, razvoj motoričkih sposobnosti (ravnoteža, koordinacija, fleksibilnost, snaga, brzina, preciznost i izdržljivost) te metode učenja motoričkih znanja. Također opisuje dosadašnja istraživanja slovenskih znanstvenika i kineziologa koji su se bavili područjem motoričkog učenja u doba ranog djetinjstva, ulogu komunikacije u procesu učenja motoričkih znanja, metode rada s djecom, ulogu igre u poučavanju, ulogu menadžmenta u motoričkom razvoju djece te inovativnost u motoričkom učenju. Na kraju priručnika navedeni su i objašnjeni izabrani najvažniji pojmovi iz područja učenja motoričkih aktivnosti te popis literature. Ovaj je priručnik važan za popularizaciju učenja i poučavanja motoričkih aktivnosti djece od ranog djetinjstva pa nadalje, a njegova vrijednost očituje se u primjerenoj i jasnoj interpretaciji znanstvenih i stručnih spoznaja te primjerima motoričkih sadržaja za rad s djecom predškolske i školske dobi. Priručnik 
će zasigurno poslužiti studentima, odgojiteljima i učiteljima u njihovom neposrednom odgojno-obrazovnom radu s djecom.

S obzirom na navedeno, smatram da priručnik doc. dr. sc. Iztoka Retara Zgodnje gibalno poučevanje predstavlja značajan doprinos u području učenja i poučavanja motoričkih aktivnosti djece od ranog djetinjstva pa nadalje te ga iskreno preporučam svima onima koji u svom neposrednom radu s djecom mogu primijeniti spoznaje koje su vrlo stručno opisane i objašnjene u priručniku.

Iva Blažević 



\section{IMENSKO KAZALO}

A

Armstrong, D. 18

B

Bahovec, E. 13

Barnett, A. L. 123

Bar, O. 18

Benavides, F. 171

Bouchard, C. 18

C

Cemič, A. 33, 34, 39, 50, 51, 55, 61, 75, 79,

83,125

Cencič, M. 171

Clohesy, P. 18

Cockerham, W. C. 163, 177

Cockerill, H. 23

Cör, A. 26

Cotič, M. 171

Cvetko, E. 26

C

Čuk, l. 109
D

Daft, R. L. 161, 162

Dolenec, M. 46

Duerden, E. G. 50

Dumont, H. 171

E

Eckert, H. 35

Epstein, D. 50, 91

Ericsson, K. A. 50

\section{G}

Gabrijelčič Blenkuš, M. 13, 17, 37, 163, 164

Gallahue, D. L. 18, 38, 39, 40, 41, 42, 43,

44,143

Getchell, N. 23

Goodway, J. D. 18

Gopnik, A. 20, 89

Graham, G. 111

Grey-Thompson, T. 13,17

H

Harrington, G. 18

Haywood, K. 23, 38, 43, 44 
Henderson, S. E. 123

Hozjan, D. 19

Huppert, J. 13

I

Istance, D. 171

\section{J}

Jelovčan, G. 50, 143

Jeriček Klajnšček, H. 163, 164

Jovan, N. 144, 147

Jurak, G. 74

K

Keeley, B. 13

Kolar, E. 19, 21

Kovač, M. 74, 109

Krajnc, M. 146

Kremžar, B. 125

Kuhl, P. K. 20

$\mathbf{L}$

Labinowicz, E. 36

Laval, C. 22

Laverdure-Dupon, D. 50

Legan, M. 26

Lepičnik Vodopivec, J. 21, 22, 133, 172

Leskošek, B. 74

Leslie, C. 13

\section{M}

Malina, R. M. 18, 34, 35, 37, 41, 43, 44

Marentič Požarnik, B. 19

Marinšek, M. 20, 90, 91

Marjanovič Umek, L. 35, 37, 143

Marš, T. 26

Martens, R. 118

Medved Udovič, V. 171

Meltzoff, A. N. 20

Musek, J. 49

\section{$\mathbf{N}$}

Nemec, B. 146

Novak, D. 109, 110

Ozmun, J. C. 18

$\mathbf{P}$

Pangrazi, R. P. 41

Pečjak, V. 49

Petelin, M. 125

Pinter, S. 46

Pišot, R. 13, 17, 18, 23, 33, 34, 35, 36, 41, 42, $43,44,46,49,50,55,75,93,109,110$, $111,130,143,145,162$

Pistotnik, B. 23, 46, 49, 50, 51, 55, 56, 61, $69,75,79,99,100,102,103,109,110$, $111,115,146,147,148$

Planinšec, J. 18, 34, 35, 36, 41, 42, 43, 44, $49,50,110$

Plevnik, M. 18, 19, 21, 110, 111

$\mathbf{R}$

Rajtmajer, D. 18, 20, 43, 90, 91, 92, 109, 125

Retar, I. 18, 19, 21, 22, 50, 109, 112, 130, 133, $161,172,173,174,175,176,177$

Robertson, M. A. 23

S

Sharma, A. 23

Sheridan, M. D. 23, 43

Stančevič, B. 147

Starc, G. 74

Stodden, D. F. 18, 23

Strah, N. 147

Strel, J. 18, 74, 125

Strmčnik, F. 109, 110, 129

Sugden, D. A. 123 
Škof, B. 18, 35, 37, 69, 109

Štemberger, T. 172

Štiblar-Martinčič, D. 26, 27, 28

Štrucl, M. 28, 29, 30

Šturm, J. 18, 125

$\mathbf{T}$

Tancig, S. 89, 109, 110

Tanner, J. M. 35

Thorndike, E. 50

$\mathbf{U}$

Ušaj, A. 69, 110

V

Videmšek, M. 18, 23, 33, 34, 36, 43, 46, 50,

$55,75,93,109,125,130,144,147,149$

Visinski, M. 46, 149

W

Walkley, J. 18

White, A. 114

$\mathbf{Z}$

Završnik, J. 13, 17

Zupančič, M. 35, 37, 143 



\section{STVARNO KAZALO}

A

asociacija 99, 102, 103, 166

avtomatizacija 29, 50, 91, 96, 99, 101, 102

D

didaktična načela 109, 130, 174

didaktika 109, 127, 128, 129, 130, 131

\section{E}

elementarne igre $73,75,78,134,144,146$, $147,148,149,150,151$

elementarni gibalni vzorci 19, 23, 37, 44,

$45,111,128,172$

\section{$\mathbf{F}$}

faze gibalnega razvoja 44, 91 faze učnega procesa 141, 142 frontalna oblika 133

\section{G}

gibalne kompetence 20, 23, 24, 40, 41, $42,44,46,50,111,128,159$

gibalne sposobnosti $13,14,17,18,19,20$, $21,23,24,37,38,40,41,42,43,49$,
$50,59,61,62,67,75,76,77,83,91,92$, $103,111,114,115,123,124,125,128$, $130,134,136,143,147,148,149,150$, $160,164,167,168,172,173,179,180$ gibalni program 20, 23, 26, 57, 58, 59, 79, $89,92,93,100,101,102,103,104,110$, 172

gibalni razvoj 13, 14, 17, 18, 19, 20, 25, 34, $37,38,39,40,41,42,43,44,45,46$, $89,114,125,140,161,162,164,165$, $166,167,168,171,173$ gibalni spomin $20,57,58,92,93,102$, 103, 160, 172

gibalni stereotip 43, 45, 91, 111, 128, 167 , 172

gibalni vzorec $39,118,124$ gibalno poučevanje $13,14,18,19,21,23$, $25,28,30,34,37,41,42,44,50,56$, $90,93,95,99,101,103,105,107,109$, $110,111,113,114,115,117,118,119,120$, $122,123,128,131,133,137,139,145$, $146,153,156,159,161,162,163,164$, $165,171,172,173,175,176,179,180$ gibalno učenje $17,18,19,20,21,23,25$, $26,30,41,89,90,91,97,104,105$, $109,110,111,113,117,119,120,121$, 
$122,128,130,142,159,172,179,180$ gibanje 14, 17, 19, 20, 23, 24, 25, 26, 28,

$38,40,42,43,44,46,53,56,57,58$,

$59,61,70,75,79,80,81,89,90,91$,

$92,93,95,100,101,102,103,105,107$,

$108,110,113,114,116,121,122,131$,

$134,144,145,147,148,149,150,151$,

$153,159,163,164,165,166,172,173$,

$174,180,181$

gibljivost $42,43,49,50,60,61,62,63,64$,

$65,66,67,77,78,84,148,150,168$

H

hitrost 21, 33, 34, 41, 42, 43, 49, 50, 55, 57, $60,62,67,69,71,75,76,77,78,80$,

$84,91,92,102,123,124,148,150,168$

I

inovativno gibalno poučevanje 21,173 , 174

$\mathbf{K}$

kognitivna vadba 173

\section{M}

metodika 141,180

mikroraztrganina 73

moč $21,37,41,42,43,49,50,55,60,62$, $65,67,69,70,71,72,73,77,78,84,91$, $102,123,148,150,151,168$

modifikacija 99, 102

motivacija 21, 23, 24, 50, 71, 77, 97, 99,

$101,109,113,114,115,124,130,142$,

$147,152,155,156,159,168,179$

motorika 30, 89, 90, 150, 152

možgani 25, 26, 27, 28, 29, 30, 35, 51, 52,

$53,63,91,97,107,120,165$

\section{N}

naravne oblike gibanja 14, 23, 34, 41, 42,

$46,59,73,75,78,144,148,167$

natančnost $42,49,50,56,60,62,74,79$,

$80,81,84,102,146,148,149,150,151$,
168

nevron 25, 26, 29

nevroznanost 25

ogrevanje $64,66,67,149,150,156,168$

\section{P}

podpora $37,56,100,107,119,123,137$, $140,141,149,156,162,164,173,174$, 180

pomoč $25,36,37,41,42,46,47,59,74$, $90,91,93,95,100,101,107,119,120$, $121,129,130,136,140,143,147,148$, $156,157,158,173$

ponavljanje $20,29,37,50,56,58,59,81$, $89,91,95,101,112,115,118,134,141$, $142,152,169$

poučevanje $13,18,19,21,22,29,37,41$, $59,89,96,99,100,103,107,110,111$, $114,115,122,127,128,129,130,131$, $133,134,135,142,144,145,155,157$, $159,162,163,164,165,171,173,174$, $175,176,177,179,180$

preverjanje 109, 118, 119, 140, 141, 157 prikaz 121

prikaz gibanja 100, 111, 118, 121, 162, 180 prilagoditev 40, 67, 73, 107, 119, 130, 173, 174

priporočilo 112, 118, 151, 152, 174

proceduralni spomin 95

\section{$\mathbf{R}$}

ravnotežje $21,28,30,37,39,41,42,43$, $49,50,51,52,53,54,55,60,61,84,91$, $148,149,150,151,168$

raztezne vaje $67,72,73$

S

sinapsa 26,71

stabilizacija 96, 99, 101, 102, 110 


\section{క̆}

športne igre 134, 146, 147, 149

štafetne igre 78, 84, 134, 148, 149, 150

$\mathbf{T}$

tekmovalni šport 116

tekmovanje $66,115,116,134,135,136$,

$141,142,150$

testiranje 123, 124, 125, 137, 140

trening 50, 144

\section{$\mathbf{U}$}

učenje $18,19,20,21,22,23,24,35,36,40$,

$43,49,59,89,90,91,93,95,97,111$,

$112,120,142,159,160,171,173,174$,

177

učitelj 18, 107, 113, 121, 123, 125, 128, 129, $130,133,134,139,163,167,171$

uČna priprava 109, 125, 139, 140, 141

učne metode 21, 109, 111, 114, 127, 128,

$129,133,135,136,140,141,162$

učne oblike 21, 109, 111, 114, 127, 128, 129,

$133,134,135,141,162$

urjenje 142

utrjevanje 92, 99, 112, 141, 148, 150, 169

\section{V}

vrednotenje 123, 124, 125, 129, 161

vzdržjivost 84

vzdržljivost $42,43,49,50,67,69,83,84$

Vzgojitelj 13, 14, 18, 19, 20, 21, 22, 24, 37 ,

$90,96,97,99,100,101,102,105,107$,

$109,111,112,113,114,117,121,123$,

$124,127,128,133,134,135,136,137$,

$139,140,143,145,149,153,155,158$,

$159,160,163,164,171,172,173,174$,

$175,177,179,181$

\section{$\mathbf{Z}$}

zaključni del 140, 142, 148, 149, 151, 169, 180, 181 
